\title{
Just Published
}

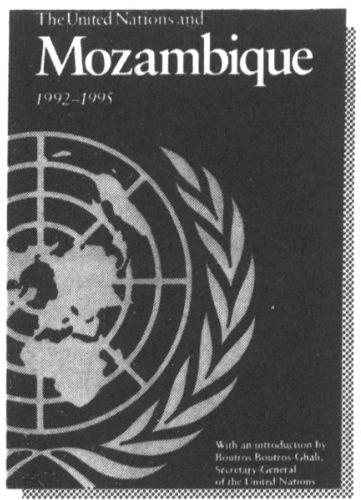

\section{The United Nations and Mozambique, 1992-1995}

$\mathrm{T}$ his essential reference work offers a comprehensive account of one of the most innovative, multifaceted and successful operations ever undertaken by the United Nations -- the United Nations Operation in Mozambique (ONUMOZ). A combined effort of peace-keeping, humanitarian aid and electoral assistance, ONUMOZ helped the Mozambican people establish a solid foundation for a peaceful future following a devastating civil conflict.

For the first time, the texts of nearly 100 key documents relating to the operation have been gathered in a single volume. Complementing the documents is an extensive introduction by Secretary-General Boutros Boutros-Ghali, which provides an overview of the Organization's contribution to the historic transformation in Mozambique. Also included are indexes and a detailed chronology of events.
E.95.I.20
92-1-100559-0
$321 p p$
$\$ 29.95$

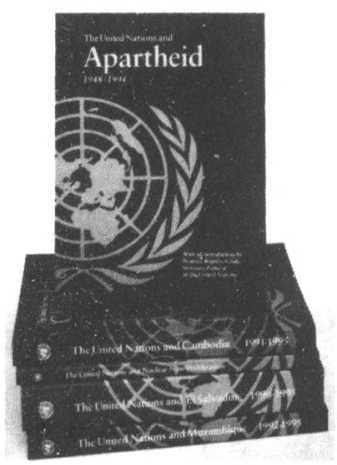

\section{The United Nations Blue Books Series}

This new series of publications will prove an invaluable research and reference tool for academics, policy makers, journalists and others interested in gaining a deeper understanding of the work of the United Nations in dealing with the major issues of concern to humanity.

In gathering together the key materials related to each issue, the books provide both a comprehensive and authoritative source of information. All will include an extensive introduction by Secretary-General Boutros Boutros-Ghali, a detailed chronology of events and a collection of documents and related information.

The reader quickly finds:

- General Assembly and Security Council Resolutions

- Reports of the Secretary-General

- The full texts of Conventions, Charters Agreements and Treaties

- Significant speeches and correspondence between parties

Each volume has been conceived to give easy access to the wealth of information they contain, with a subject index and a bibliography of documents. In addition, each passage of the overview is cross-referenced to the corresponding documents.

Other current titles in the series include:

- The United Nations and Apartheid, 1948-1994

- The United Nations and Cambodia, 1991-1995

- The United Nations and Nuclear Non-Proliferation

- The United Nations and El Salvador, 1990-1995

Each is available at $\$ 29.95$

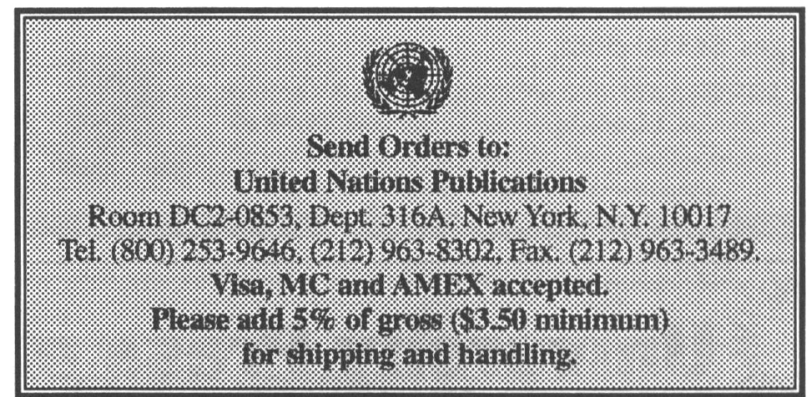




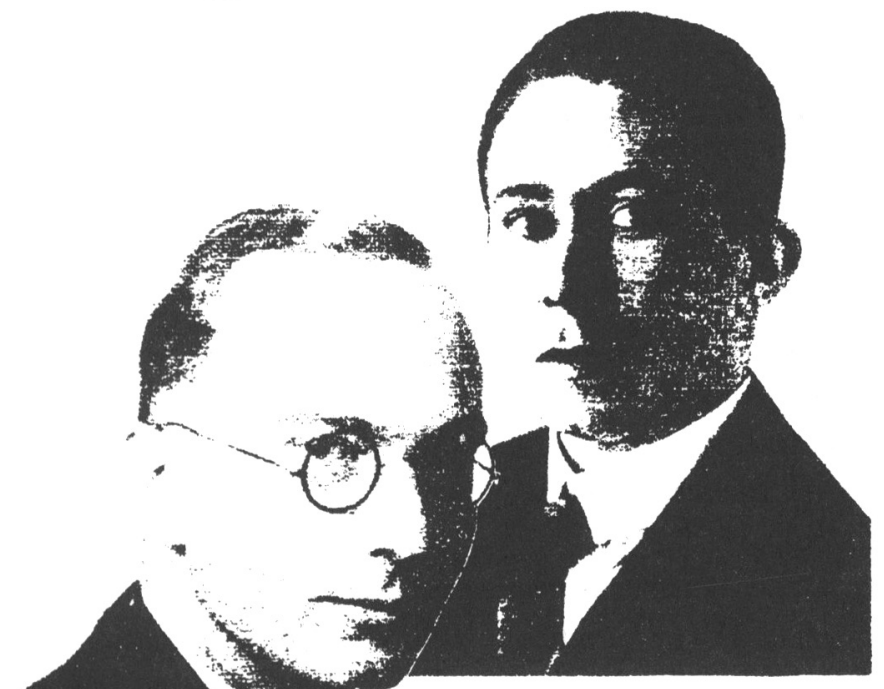

Revolt Against Modernity

Leo Strauss, Eric Voegelin, and the Search for a PostLiberal Order Ted V. McAllister "McAllister traces an American counter-tradition

in the work of thinkers for whom modernity was as much tragedy as triumph. An important contribution to our self-understanding as well as to the history of ideas." - JEAN BETHKE Elshtain, author of Democracy on Trial. "Lucidly examines the major works of Leo Strauss and Eric Voegelin for an understanding of the origins and nature of our modern predicament. 'Must' reading for an appreciation of the theoretical foundations of modern American Conservative thought which, as McAllister makes clear, owes so much to these two giants."

- George W. Carey, editor of The Political Science Reviewer. 304 pages. $\$ 29.95$

Available at bookstores or from the press Phone 913-864-4155 Fax 913-864-4586 VISA and MasterCard accepted

\section{Battles on the Bench}

Conflict Inside the Supreme Court Phillip J. Cooper

"A superb study. Cooper has produced a work that is in many ways seminal. He has also done an excellent job of classsifying the nature, types, and consequences of conflict on the Court, illustrating each with amusing, touching, gripping, shocking, and at times profound anecdotes. Highly recommended." - Tinsley E. Yarbrough, author of John Marshall Harlan. "Cooper's book in some ways covers ground found in The Brethren but is superior to that book. He weaves a fascinating story and provides sound political analysis." - SHELdon GoldmaN, author of Constitutional Law and Supreme Court Decision Making.

224 pages. $\$ 24.95$

John A. Rohr

"Rots an outstanding scholar who mon with this comparative legal and intellectual history of the French and U.S. constitutions regarding public administration. A very significant contribution to the field." - DAvid Rosenbloom, author of Public Administration and the Law. "A solid scholarly contribution to our understanding of France and to comparative politics and public law. The U.S.-French comparison is not only intrinsically interesting but it has hardly ever been attempted in the detail presented here." - William Safran, author of The French Polity.

400 pages. $\$ 45.00$ cloth,

$\$ 19.95$ paper

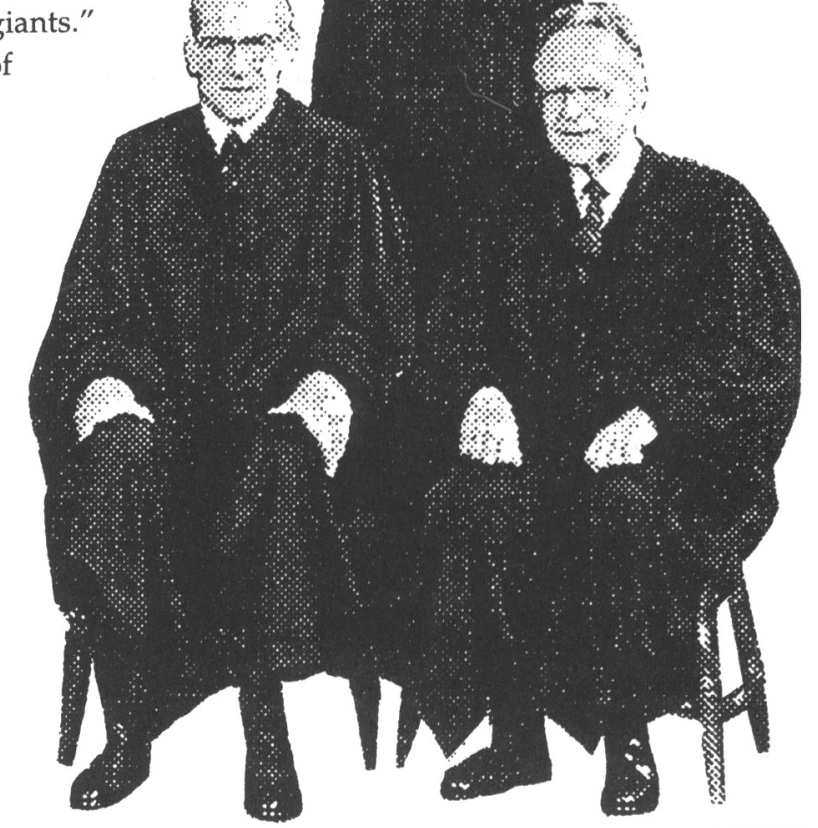




\section{NEW FROM}

\section{CPRENWOOD PRESS PRAEGER}

\section{Democratization and the Protection of Human Rights in Africa \\ Problems and Prospects By Brendalyn P. Ambrose}

Argues that it is not feasible to promote liberal democracy and civil rights in Africa without first addressing the material and intellectual poverty of the majority.

Praeger Publishers. 1995. 248 pages. 0-275-95143-X. $\$ 57.95$

\section{Warnings from the Far South \\ Democracy versus Dictatorship \\ in Uruguay, Argentina, and Chile \\ By William Columbus Davis}

This work examines three advanced Latin American republics with long records of democracy, political stability, and economic prosperity which degenerated into instability and military dictatorship-and issues a warning for other democratic peoples.

Praeger Publishers. 1995. 256 pages. 0-275-95021-2. \$59.95

\section{The American Presidency \\ Second Edition \\ By James W. Davis}

"A superior text in all respects. It is comprehensive, carefully researched, peppered with insights, even handed, and a delight to read. Any student who seeks to understand the essence of the modern American presidency will acquire that understanding in the reading of this thorough and thoughtful text."

Thomas E. Patterson Professor of Political Science Maxwell School of Citizenship and Public Affairs Syracuse University

Praeger Publishers. 1995. 0-275-94874-9. \$70.00 Est.

A paperback edition is available: 0-275-94875-7. \$25.00 Est.

\section{Social Security Programs}

\section{A Cross-Cultural Comparative Perspective}

Edited by John Dixon and Robert P. Scheurell

Contributions in Political Science, No. 359

Prepared under the auspices of the Policy Studies Organization

Stuart S. Nagel, Publications Coordinator

This volume examines current trends in social security programs around the world, offering cross-cultural perspectives from an international group of experts.

Greenwood Press. 1995. 256 pages. 0-313-29654-5. \$57.95

\section{Afrocentrism and World Politics \\ Towards a New Paradigm \\ By Errol Anthony Henderson}

A critical study of both Afrocentrism as an approach and Eurocentric political science as a discipline, building from both without abandoning the best of either. This work challenges Eurocentrism to abandon hegemony and Afrocentrism to be scientific.

Praeger Publishers. 1995. 240 pages. 0-275-95127-8. $\$ 55.00$

\section{Perspectives on the Politics of Abortion Edited by Ted G. Jelen}

Perspectives on the Politics of Abortion examines the abortion issue from ethical, empirical, and legal angles, offering some rather unconventional analyses and surprising conclusions with regard to this familiar issue.

Praeger Publishers. 1995. 216 pages. 0-275-95225-8. \$49.95

\section{Toward a Caring Society \\ Ideas into Action \\ By Pearl M. Oliner and Samuel P. Oliner}

"The Oliners have given us a comprehensive, practical guide toward building caring institutions. Using many fascinating reallife accounts, they show what can be done when individuals and groups respond to the common human desire for care. Essential reading for a troubled and violent society." Nel Noddings Lee Jacks Professor of Education, Stanford University

Praeger Publishers. 1995. 256 pages. 0-275-95198-7. $\$ 59.95$

A paperback edition is available: $0-275-95453-6 . \$ 19.95$

\section{The Theory and Practice of Third World Solidarity By Darryl C. Thomas}

Examines the development of Third World solidarity as a reaction to the historic hegemony of the developed world.

Praeger Publishers. 1995. 328 pages. 0-275-92843-8. \$55.00

\section{Governing Through Turbulence}

Leadership and Change

in the Late Twentieth Century

By David F. Walsh, Paul J. Best, and Kul B. Rai

This important new study examines aspects of political leadership and governance in the last decades of the 20th century, using a case study analysis of seven leaders on the world stage.

Praeger Publishers. 1995. 264 pages. 0-275-95166-9. \$65.00 A paperback edition is available: $0-275-95167-7$. $\$ 24.95$

\section{State-Local Relations \\ A Partnership Approach, Second Edition \\ By Joseph F. Zimmerman}

This is a revision and update of Zimmerman's classic study of relations between state and local government.

Praeger Publishers. 1995. 272 pages. 0-275-95069-7. \$65.00

A paperback edition is available: 0-275-95235-5. \$18.95

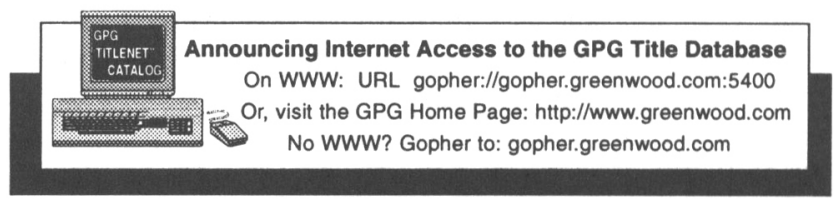



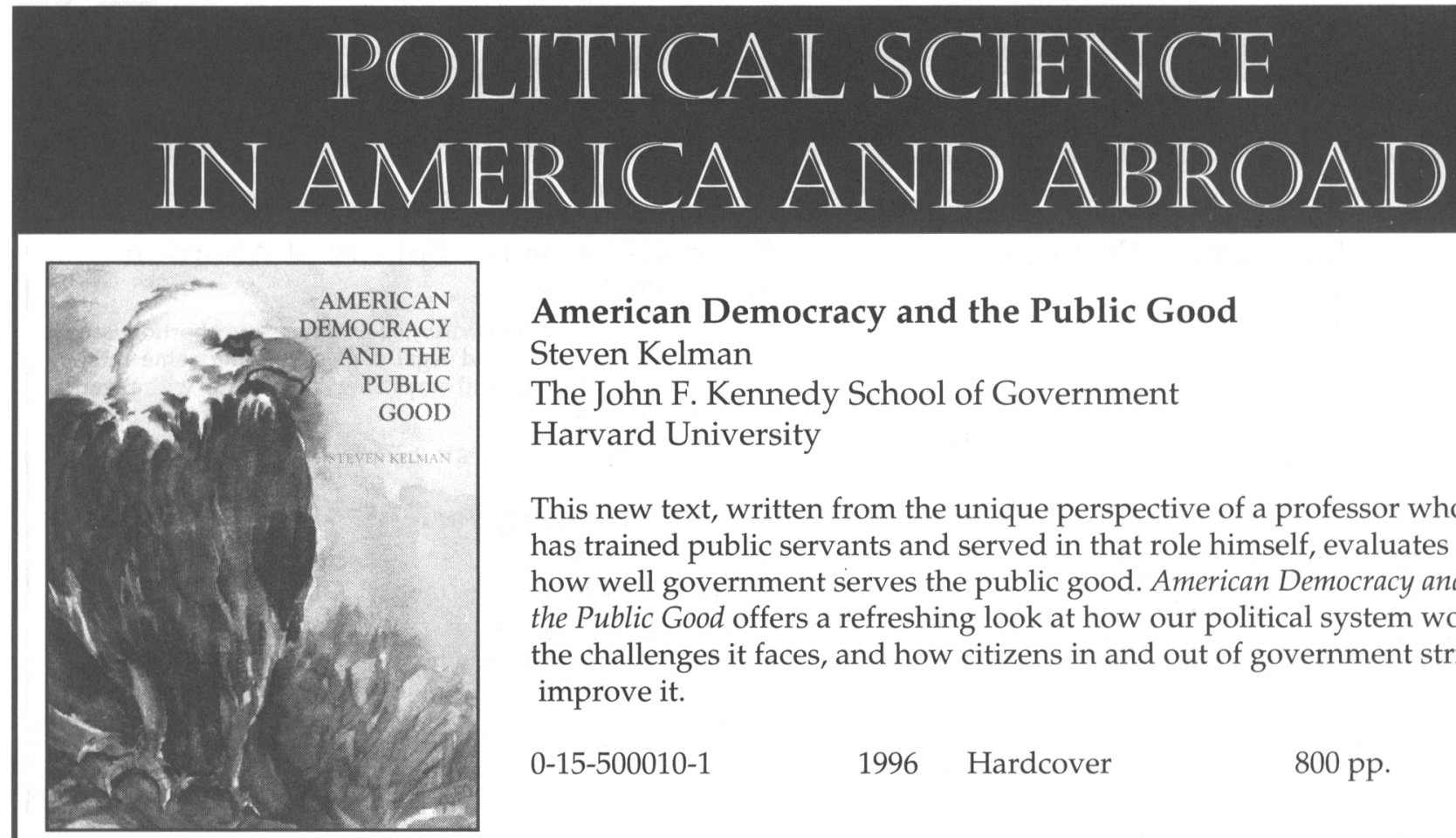

\author{
American Democracy and the Public Good \\ Steven Kelman \\ The John F. Kennedy School of Government \\ Harvard University
}

This new text, written from the unique perspective of a professor who has trained public servants and served in that role himself, evaluates how well government serves the public good. American Democracy and the Public Good offers a refreshing look at how our political system works, the challenges it faces, and how citizens in and out of government strive to improve it.

0-15-500010-1 1996 Hardcover $800 \mathrm{pp}$.

\title{
The Chief Executive, Sixth Edition
}

Louis W. Koenig, University of New York

This insightful revision addresses the historic and contemporary presidency in its full range of functions.

0-15-503176-7 1996 Paper 465 pp.

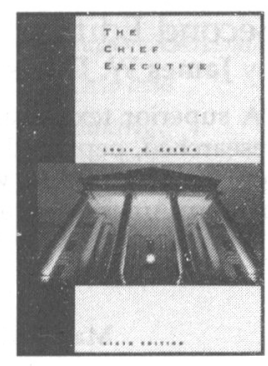

\section{International Relations}

\section{Conflict and Cooperation: Evolving Theories of International Relations \\ Marc A. Genest, University of Rhode Island}

This anthology divides international relations theory into three categories of analysis: international theories, domestic theories, and individual theories.

0-15-501500-1 1996 Paper 576 pp.

\section{World Politics in a New Era}

Steven Spiegel, University of California-Los Angeles

Spiegel's innovative text is written from a post Cold War perspective and presents material in a building-block fashion; he begins with history, proceeds to issues, and concludes with theory.
0-03-047574-0
1995
Paper
$770 \mathrm{pp}$. 


\section{AMERICAN POLITICS}

\section{Democracy and}

Diplomacy

The Impact of Domestic Politics on U.S. Foreign Policy, I789-1994

MELVIN SMALL

In this first historical overview of the subject, Melvin Small examines the central role of domestic politics in the shaping and conduct of American foreign policy from the early republic to the end of the Cold War. While accounting for various factors like special interest groups (including agriculture and business), public opinion, the media, elections and party politics, executive-legislative conflicts, Small's discussion focuses on American presidents and the bureaucrats who fashion and carry out foreign policy.

The American Moment

Stanley I. Kutler, Series Editor

\$13.95 paperback

\section{The Boundaries of Citizenship}

Race, Ethnicity, and Nationality in the Liberal State JEFF SPINNER

Liberalism has traditionally been equated with protecting the rights of the individual. But how does this protection affect the cultural identity of these individuals? A timely look at how cultural identities are formed and transformedand why the political implications of this process are so important.

$\$ 14.95$ paperback

\section{Cities without Suburbs \\ second edition \\ DAVID RUSK}

"Every mayor, every governor, every county executive, indeed anyone who cares about our great but ailing cities ought to read it."

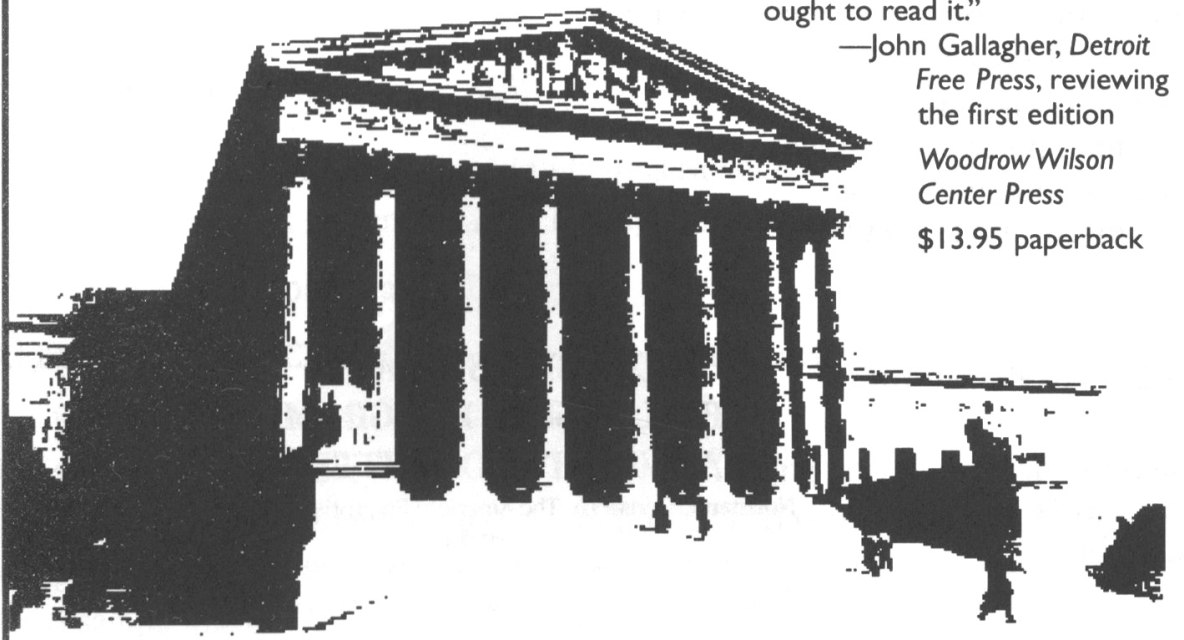

Documentary History of the First Federal Congress Debates in the House of Representatives: Third Session

Volume XIV: December I790-March I79I

EDITED BY WILLIAM C.

DIGIACOMANTONIO, KENNETH

R. BOWLING, CHARLENE BANGS BICKFORD, AND HELEN E. VEIT

"A treasure-trove of incomparable knowledge about the beginnings of Congress."-Presidential Studies Quarterly, reviewing a previous volume

$\$ 75.00$ hardcover

\section{Between Justice and Beauty}

Race, Planning, and the Failure of Urban Policy in Washington, D.C. HOWARD GILLETTE JR.

As the only American city under direct congressional control, Washington has served historically as a testing ground for federal policy initiatives and social experiments-with decidedly mixed results. Howard Gillette traces the ambiguous legacy of congressional involvement in Washington's urban development from 1790 to Marion Barry. $\$ 32.95$ hardcover

\section{INTERPRETING AMERICAN POLITICS \\ Michael Nelson, Series Editor}

The Selling of Supreme Court Nominees JOHN ANTHONY MALTESE

"John Anthony Maltese sets out to explain how the confirmation process of Supreme Court nominees has arrived at its present point-and he succeeds admirably by interweaving historical and contemporary materials. He demonstrates precisely when and how interest groups became involved in the process and when and how the White House became actively involved in, as he puts it, 'selling' the nominees."--Sheldon Goldman, University of Massachusetts, Amherst

$\$ 26.95$ hardcover

\section{The Two Majorities}

The Issue Context of

Modern American Politics

BYRON E. SHAFER AND

WILLIAM J. M. CLAGGETT

In The Two Majorities Byron Shafer and William Claggett offer groundbreaking political analysis that resolves many of the seeming contradictions in the contemporary American political scene. Drawing on an unusually large sample of all Americans conducted by the Gallup organization, Shafer and Claggett argue that the recent turbulence in American politics is in some ways superficial. Below the surface, they contend, the political preferences of the American people remain remarkably stable.

$\$ 14.95$ paperback

\section{The Foundation of Merit} Public Service in American Democracy PATRICIA WALLACE INGRAHAM

In the first systematic examination of the federal civil service in nearly forty years, Patricia Ingraham analyzes the historical development of the civil service in the context of the political and democratic environment that is central to its effectiveness and legitimacy. She describes the incremental and disjointed growth of the federal civil service and explains why-in its current form - it has little hope of meeting the enormous challenges of the next century.

$\$ 14.95$ paperback 


\section{The American Political Science Association announces the 1996-97}

\section{APSA-MCI \\ COMMUNICATIONS FELIOWSHIPS}

CONGRESSIONAL FELLOWSHIPS FOR SCHOLARS AND JOURNALSTS who have an analytical interest in communications and public policy and who show promise of making a significant contribution to the public's understanding of the political process.

THE FELLOWSHIP YEAR: A comprehensive three-week orientation period, followed by full time assignments as legislative aides in the House of Representatives and/or Senate, combined with a seminar program with leading congressional, governmental and academic figures. Orientation begins November 1996, legislative office assignments run December 1996 through August 15, 1997.

QUALIFICATIONS FOR SCHOLARS: Applications are welcome from scholars in all disciplines who have completed a Ph.D. in the last 15 years or are near completion of their dissertations.

QUALIFICATIONS FOR JOURNALISTS: A Bachelor's degree and a minimum of two years' full-time experience in newspaper, magazine, radio or television reporting at time of application. (Broadcast jcurnalists' background may be on the air or as producers, directors, writers or researchers).

FOR ALL CANDIDATES, preference given to those who have not had extensive Washington experience. Applicants who are not current residents of the United States must be able to fund their own transportation to Washington to be interviewed should they be selected as finalists.

STIPEND: $\$ 28,000$, plus a small travel allowance.

TO APPLY: Between October 1 and December 1, 1995, submit:

- a detailed resume ( 8 copies);

- a 500-word explanation of how the Congressional Fellowship Program relates to your career goals and interest in telecommunications and public policy ( 8 copies);

- For scholars: one published article constituting your best professional writing ( 8 copies) or, for journalists: a sample of your best professional writing ( 8 copies of clips or radio/television scripts or single copy of cassette or VHS tape).

REFERENCES: All candidates must submit the names of three professional references who will send letters of recommendation to the APSA office by December 15 , 1995. (Applicants are responsible for seeing that these letters are sent.)

MAIL TO: APSA-MCI Communications Fellowships, American Political Science Association, 1527 New Hampshire Avenue, NW, Washington, DC 20036. Awards will be announced by April 1, 1996

$$
\begin{aligned}
& \text { CONGRESSIONAL } \\
& \text { FELLOWSHIP PROGRAM } \\
& \text { ADVISORY COMMITTEE } \\
& \text { Norman J. Ornstein, The American Enterprise Institute, } \\
& \text { Chairman } \\
& \text { Michael Barone, U.S. News \& World Report } \\
& \text { The Honorable Walter D. Broadnax, Department of Health and } \\
& \text { Human Services } \\
& \text { David S. Broder, The Washington Post } \\
& \text { The Honorable Robert Dole, Majority Leader of the Senate } \\
& \text { Eugene Eidenberg, } \mathrm{MCI} \text { Communications Corporation } \\
& \text { Thomas S. Foley, Akin, Gump, Strauss, Hauer \& Feld } \\
& \text { David R. Gergen, The Aspen Institute } \\
& \text { The Honorable Steve Horn, United States House of Representatives } \\
& \text { Albert R. Hunt, Wall Street Journal } \\
& \text { Gerald J. Kovach, MCI Communications Corporation } \\
& \text { The Honorable Richard G. Lugar, United States Senate } \\
& \text { Philip Meyer, University of North Carolina } \\
& \text { Leonard Parkinson, Atlantic Research Corporation } \\
& \text { The Honorable Richardson Preyer } \\
& \text { David Price, Duke University } \\
& \text { Cokie Roberts, National Public Radio and ABC } \\
& \text { Robert M. Rosenzweig } \\
& \text { The Honorable Paul Simon, United States Senate } \\
& \text { Barbara Sinclair, University of California - Riverside } \\
& \text { Neil Skene, Congressional Quarterly Inc. } \\
& \text { The Honorable Janet D. Steiger, Federal Trade Commission } \\
& \begin{array}{l}
\text { Charls E. Walker, Walker/Potter Associates } \\
\text { Vin Weber, The Weber Group } \\
\text { AMERICAN POLITICAL SCIENCE ASSOCIATION } \\
\text { CONGRESSIONAL FELLOWSHIP PROGRAM }
\end{array}
\end{aligned}
$$

Funded by MCI Communications Corporation 


\section{POLITICALSCIENTISTS}

\section{The American Political Science Association announces the 1996-97 \\ Congressional Fellowship Program}

WHO: Early and mid-career political scientists.

WHY: To learn more about the legislative process through direct participation.

HOW: A comprehensive three-week orientation period; full-time assignments as legislative aides in the House of Representatives and/or Senate; seminar program with leading congressional, governmental and academic figures.

QUALIFICATIONS: A scholarly interest in Congress and the policymaking process; a Ph.D. completed within the last fiffeen years (or near completion). Applicants who are not current residents of the United States must be able to fund their own transportation to Washington to be interviewed should they be selected as finalists.

THE FELLOWSHIP YEAR: Orientation begins November 1996; office assignments run December 1996 through August 15, 1997.

STIPEND: $\$ 28,000$, plus travel allowance.

APPLICATION PROCEDURE: Submit eight copies each of:

- a detailed curriculum vitae;

- a personal statement (about 500 words) explaining how the Congressional Fellowship Program relates to your professional goals;

- a sample of your best writing (one published or unpublished manuscript).

Submit, also, the names of three professional reftrences who have agreed to write letters of recommendation.

REFERENCES: Candidates are responsible for arranging that the letters of recommendation arrive in our offices by December 15, 1995.

\section{APPLICATION DEADLINE: December 1,} 1995; mail to Director, Congressional Fellowship Program, American Political Science Association, 1527 New Hampshire Avenue, NW, Washington, DC 20036.

Awards will be announced by April 1, 1996.

\section{CONGRESSIONAL}

FELLOWSHIP PROGRAM

ADVISORY COMMITTEE

Norman J. Ornstein, The American Enterprise Institute, Chairman

Michael Barone, U.S. News \& World Report

The Honorable Walter D. Broadnax, Department of Health and Human Services

David S. Broder, The Washington Post

The Honorable Robert Dole, Majority Leader of the Senate

Eugene Eidenberg, MCI Communications Corporation

Thomas S. Foley, Akin, Gump, Strauss, Hauer \& Feld David R. Gergen, The Aspen Institute

The Honorable Steve Horn, United States House of Representatives Albert R. Hunt, Wall Street Journal

Gerald J. Kovach, MCI Communications Corporation

The Honorable Richard G. Lugar, United States Senate Philip Meyer, University of North Carolina

Leonard Parkinson, Atlantic Research Corporation The Honorable Richardson Preyer David Price, Duke University

Cokie Roberts, National Public Radio and ABC Robert M. Rosenzweig

The Honorable Paul Simon, United States Senate

Barbara Sinclair, University of California - Riverside Neil Skene, Congressional Quarterly Inc. The Honorable Janet D. Steiger, Federal Trade Commission Charls E. Walker, Walker/Potter Associates Vin Weber, The Weber Group

American POLITical Science Association CONGRESSIONaL FeLLOWSHTP Program 


\section{Jeffery J. Mondak}

\section{Nothing to Read}

Newspapers and Electlons in a Social Experiment

To what extent would the average citizen go to obtain information about candidates should a media source suddenly be suspended during an election? Not far, says conventional wisdom. Comparing Pittsburgh and Cleveland during the 1992 campaign season-when Pittsburgh was in the midst of a newspaper strike-Mondak tested that conventional wisdom and proved it wrong.

cloth $\$ 37.50$

paper $\$ 16.95$

\section{Alice Holmes Cooper \\ Paradoxes of Peace}

\section{German Peace Movements} since 1945

This comprehensive examination of peace activism in postwar Germany explores the development of an organizational infrastructure that is autonomous of parties and other social institutions.

cloth $\$ 49.50$

Jacek Kugler and Douglas Lemke, Editors

\section{Parity and War}

Evaluations and Extensions of The War Ledger

This discussion of power preponderance-introduced in The War Ledger over a decade ago-explains why peace predominates in the international arena and why, on occasion, wars do start.

cloth $\$ 52.50$

paper $\$ 19.95$

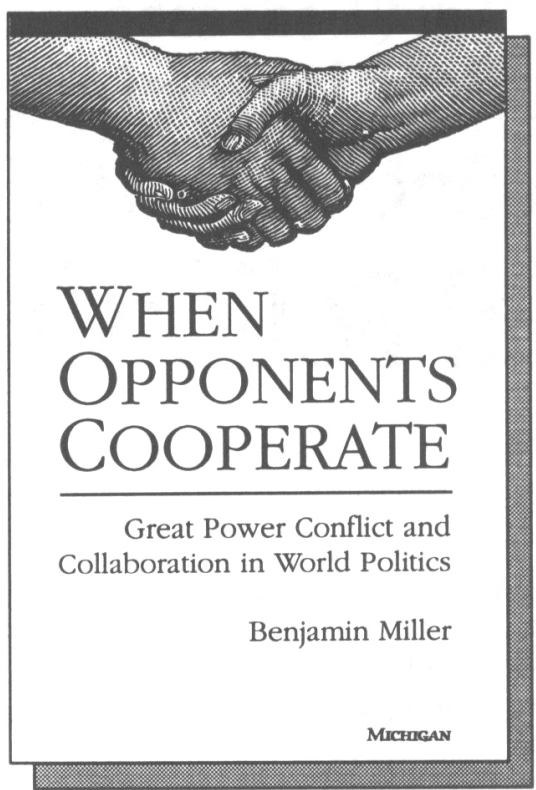

Benjamin Miller

When Opponents Cooperate

Great Power Conflict and Collaboration in World Politics

"Benjamin Miller offers in this comprehensive and sophisticated book an impressive synthesis of some of the most important analytical perspectives in international relations theory. This lucid reexamination of theoretical approaches will be especially welcome by those seeking to reexamine basic assumptions that have been put into question by the end of the Cold War."

-Peter J. Katzenstein, Cornell University cloth $\$ 49.50$

Jack Knight and Itai Sened, Editors

\section{Explaining Social Institutions}

An innovative exploration of how institutions emerge and become influential.

cloth $\$ 39.50$

Karl Dieter Opp, Peter Voss, and Christiane Gern

\section{Origins of Spontaneous Revolution} East Germany 1989

Explores the extraordinary collapse of Communist East Germany. A volume in the Economics, Cognition, and Society series.

cloth $\$ 45.00$

\section{Mark Irving Lichbach \\ The Cooperator's Dilemma}

Prisoner's Dilemma and public goods issues are discussed within collectiveaction framework. A volume in the Economics, Cognition, and Society series.

cloth $\$ 39.50$

OF RELATED INTEREST

Mark Irving Lichbach

The Rebel's Dilemma cloth $\$ 45.00$

John R. Freeman, Editor

Political Analysis An Annual Publication of the Methodology Section of the American Political Science Association

Volume 5

cloth $\$ 44.50$ 


\section{NEW $\mathcal{E}$ NOTEWORTHY FROM ST. MARTIN'S PRESS}

\section{American Politics}

NEW

$\circlearrowleft$

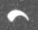

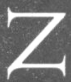

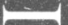

[

$\propto$

NEW
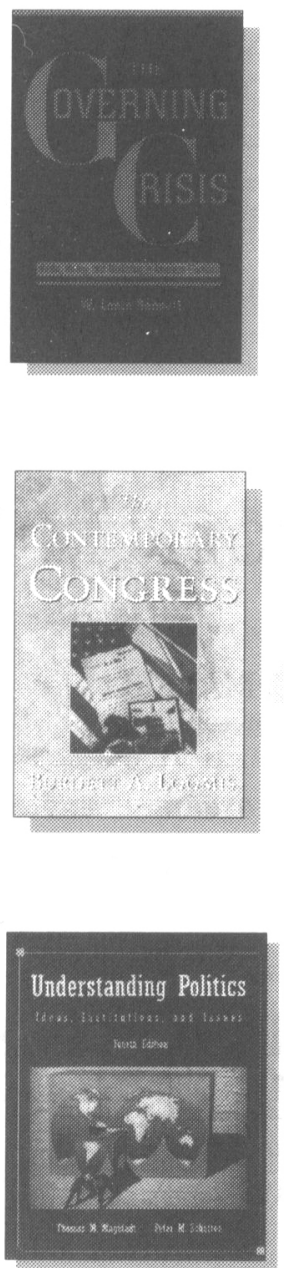

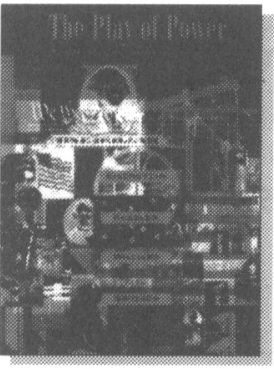

\section{THE PLAY OF POWER}

An Introduction to American Government

JAMES EISENSTEIN, The Pennsylvania State University

- MARK KESSLER, Bates College BRUCE A. WILLIAMS, University of Illinois at Urbana-Champaign - JACQUELINE VAUGHN SWITZER, Southern Oregon State College

November 1995

Complete Edition: Cloth / 864 pp. / ISBN 0.312-08655.5

Basic Edition (without policy chapters): Paper / 752 pp. / ISBN 0.312-13662-5 Full ancillary package available

\section{NEW EDITION}

\section{THE GOVERNING CRISIS}

Media, Money, and Marketing in American Elections

Second Edition

W. LANCE BENNETT, University of Washington

September 1995 / Paper / 288 pp. / ISBN 0-312-11615-2

\section{THE CONTEMPORARY CONGRESS}

BURDETT A. LOOMIS, University of Kansas

January 1996 / Paper / 272 pp. / ISBN 0-312-10399-9

NEW EDITION

\section{UNDERSTANDING POLITICS}

Ideas, Institutions, and Issues

Fourth Edition

THOMAS M. MAGSTADT, University of Nebraska at Kearney

PETER M. SCHOTTEN, Augustana College

August 1995 / Paper / 624 pp. / ISBN 0-312-11593-8

Instructor's Manual available

St. Martin's Press • College Division

345 Park Avenue South, New York, NY 10010 $1-800-446-8923$

Fax:(212)686-9492 


\section{NEW $\mathcal{E}$ NOTEWORTHY}

$\infty$

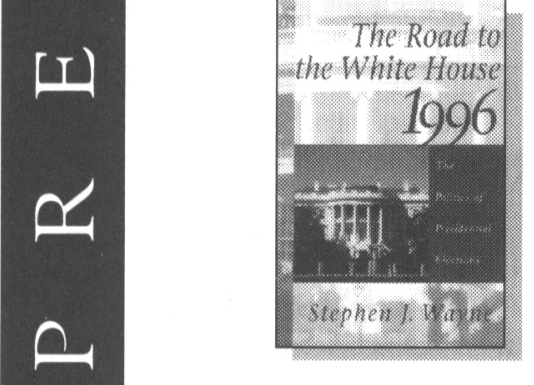

NEW EDITION

THE ROAD TO THE WHITE

HOUSE, 1996

The Politics of Presidential Elections

Fifth Edition

STEPHEN J. WAYNE, Georgetown University

August 1995 / Paper / 336 pp. / ISBN 0.312-10593-2

\section{Public ADMINISTRATION}

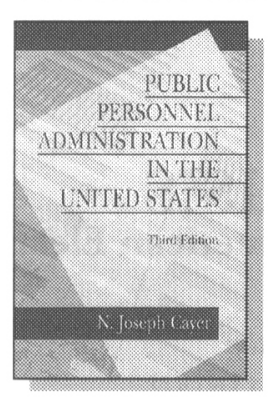

NEW EDITION

PUBLIC PERSONNEL

ADMINISTRATION IN THE

UNITED STATES

Third Edition

N. JOSEPH CAYER, Arizona State University

January 1996 / Paper / 352 pp. / ISBN 0.312-11611-X

Public Policy

[

$\propto$

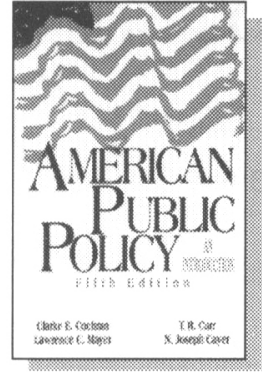

NEW EDITION

AMERICAN PUBLIC POLICY

An Introduction

Fifth Edition

CLARKE E. COCHRAN and LAWRENCE C. MAYER, both of Texas Tech

University T. R. CARR, Southern Illinois University at Edwardswille

- N. JOSEPH CAYER, Arizona State University

September 1995 / Paper / 512 pp. / ISBN 0-312-11616-0

\section{RESEARCH METHODS}

NEW

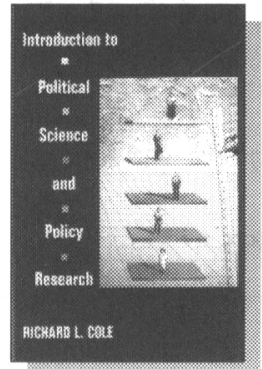

\section{INTRODUCTION TO POLITICAL} SCIENCE AND POLICY RESEARCH

RICHARD L. COLE, University of Texas at Arlington

October 1995 / Paper / 304 pp. / ISBN 0-312-07192-2

Instructor's Manual available

St. Martin's Press • College Division

345 Park Avenue South, New York, NY 10010

$1-800-446-8923$

Fax:(212)686-9492 


\section{From ST. MARTIN'S PRESS}

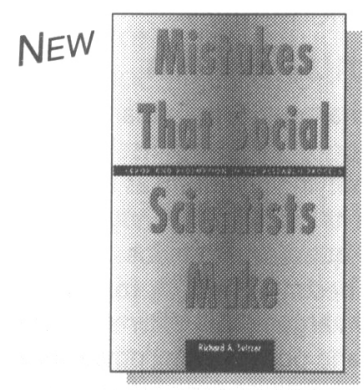

MISTAKES THAT SOCIAL SCIENTISTS MAKE

Error and Redemption in the Research Process

RICHARD A. SELTZER, Howard University

August 1995 / Paper / 160 pp. / ISBN 0.312-12003-6

NEW

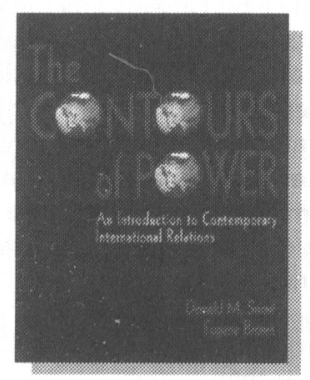

\section{THE CONTOURS OF POWER}

An Introduction to Contemporary International Relations DONALD M. SNOW, University of Alabama

EUGENE BROWN, Lebanon Valley College

November 1995 / Paper / 560 pp. / ISBN 0-312-11635-1

Instructor's Manual available
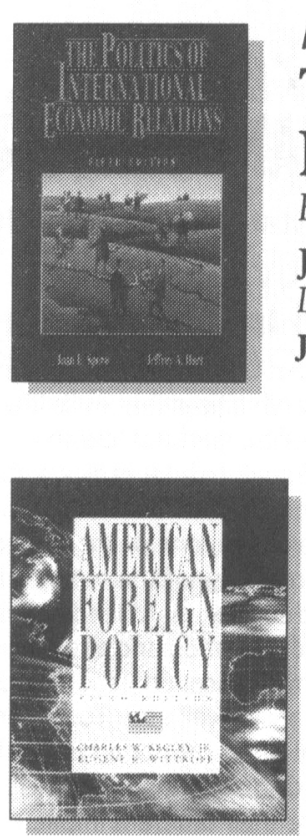

NEW EDITION

THE POLITICS OF INTERNATIONAL ECONOMIC RELATIONS

\section{Fifth Edition}

JOAN SPERO, Under Secretary of State for Economic and Agricultural Affairs, Department of State JEFFREY A. HART, Indiana University

January 1996 / Paper / 416 pp. / ISBN 0-312-08476-5

\section{NEW EDITION}

\section{AMERICAN FOREIGN POLICY}

Pattern and Process

Fifth Edition

EUGENE R. WITTKOPF, Louisiana State University CHARLES W. KEGLEY, JR., University of South Carolina

January 1996 / Paper / 688 pp. / ISBN 0-312-07536-7

St. Martin's Press • College Division 


\section{PRINCETON UNIVERSITY PRESS}

\section{FACING UP TO THE AMERICAN DREAM}

Race, Class, and the Soul of the Nation

\section{Jennifer L. Hochschild}

The ideology of the American dreamthe faith that an individual can attain success and virtue through strenuous effort-is the very soul of the American nation. According to Jennifer Hochschild, we have failed to face up to what that dream requires of our society, and yet we possess no other central sustaining belief.

In this compassionate but frightening book, Hochschild combines survey data and vivid anecdote to clarify several paradoxes. Since the 1960s white Americans have seen African Americans as having better and better chances to achieve the dream. At the same time middle-class blacks have become increasingly frustrated personally and anxious about the progress of their race. Most poor blacks, however, cling to the notion that they and their families can succeed. Meanwhile, a tiny number of the estranged poor, who have completely given up on the American dream or any other faith, threaten the social fabric of the black community.

This is a thoughtful, troubling view of the American dream as it is lived today.

"This is a timely and important book. Hochschild's analysis of the paradoxes of race and class in America is both brilliant and refreshing. Facing Up to the American Dream should be read by every American who has grown weary over and is puzzled by the nature of the racial rhetoric featured in so much of our public discourse."-William Julius Wilson

"In this invaluable study, Jennifer Hochschild compares the views of middle-class and poor African Americans to measure the current significance of the American Dream belief-system and cogently assesses the likelihood that a sustaining article of American faith could carry with it the seeds of social destruction."-Derrick Bell

Princeton Studies in American Politics

Ira Katznelson, Martin Shefter, and Theda Skocpol, Editors Cloth: \$29.95 ISBN 0-691-02957-1

Available September 1995

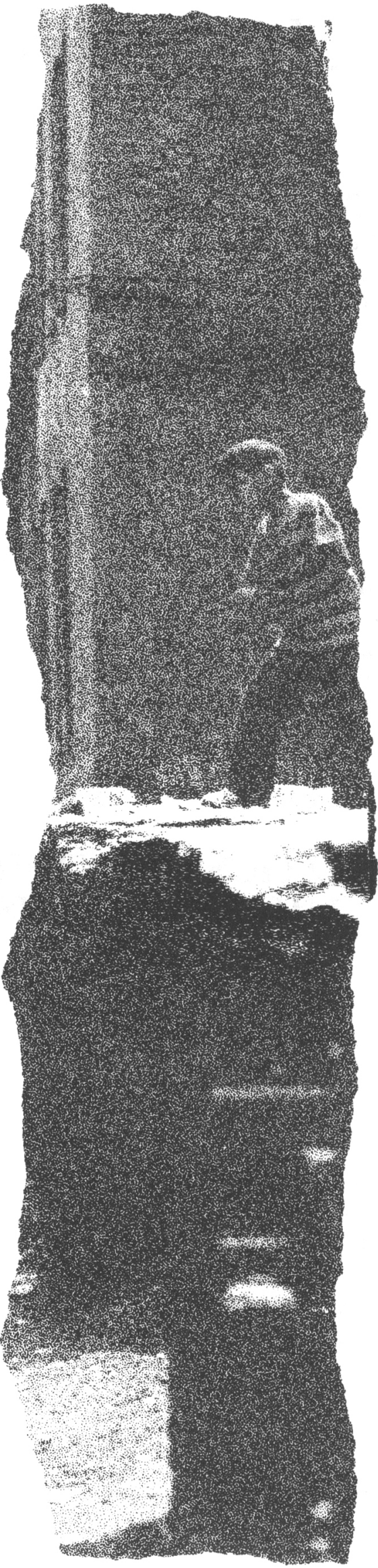

\section{STATES OF INJURY}

\author{
Power and Freedom in Late \\ Modernity \\ Wendy Brown
}

Whether in characterizing Catharine MacKinnon's theory of gender as itself pornographic or in identifying liberalism as unable to make good on its promises, Wendy Brown pursues a central question: how does a sense of woundedness become the basis for a sense of identity? Brown argues that efforts to outlaw hate speech and pornography powerfully legitimize the state: victims are portrayed as so helpless as to be in continuing need of governmental protection. True democracy, she insists, requires sharing power, not regulation by it.

"Wendy Brown refuses any easy identification with trends in political theory. Instead, she analyzes the main traditions of critical theory with care and original insight. Her analysis of the relationship between freedom and equality brings the best of postmodern insight to bear on one of liberalism's most cherished values." -Drucilla Cornell

Paper: \$12.95 ISBN 0-691-02989-X Cloth: \$39.50 ISBN 0-691-02990-3 Available October 1995

\section{PATHS OF EMANCIPATION}

Jews, States, and Citizenship

\section{Edited by Pierre Birnbaum and Ira Katznelson}

Throughout the nineteenth century, legal barriers to Jewish citizenship were lifted in Europe, enabling organized Jewish communities and individuals to alter radically their relationships with the institutions of the Christian West. In this volume, one of the first to offer a comparative overview of the entry of Jews into state and society, eight leading historians analyze the course of emancipation in Holland, Germany, France, England, the United States, and Italy as well as in Turkey and Russia. Their goal is to produce a systematic study of the highly diverse paths to emancipation and to explore their different impacts on Jewish identity, dispositions, and patterns of collective action.

In addition to the editors, the contributors are Geoffrey Alderman, Hans Daalder, Werner E. Mosse, Aron Rodrigue, Dan V. Segre, and Michael Stanislawski.

Paper: \$16.95 ISBN 0-691-03461-3 Cloth: \$42.50 ISBN 0-691-03460-5 


\section{NEW IN PAPERBACK}

\section{AMERICA'S MISSION}

The United States and the

Worldwide Struggle for

Democracy in the Twentieth Century

\section{Tony Smith}

"[Smith's] account of the 20th century is just about as close to unputdownable as it gets in the genre of political history, and ends up advocating what seems to be an appropriate level of optimism for what remains, after all, a terrifying and chaotic world. "-Washington Post

"No one concerned with America's role in the world can afford to ignore the powerful argument and impressive scholarship of this landmark study." - Ronald Steel

"There simply is no comparable volume."-Stanley Hoffman

A Twentieth Century Fund Book Princeton Studies in International History and Politics John Lewis Gaddis, Jack L. Snyder, and Richard H. Ullman, Editors

Now in paper: \$16.95 ISBN 0-691-04466-X

\section{WEALL LOST THE COLDWAR}

\section{Richard Ned Lebow and Janice Gross Stein}

"Lebow and Stein have written an analytical gem, a comparison of the 1962 Cuban missile crisis and the October 1973 Arab-Israeli war. . . . A better introduction to these two Cold War events, in which 'we all lost,' does not exist." - Choice

"A book that everyone concerned with the future as much as the past of international affairs should read." - Len Scott, Times Higher Education Supplement Princeton Studies in International History and Politics John Lewis Gaddis, Jack L. Snyder, and Richard H. Ullman, Editors

Now in paper: \$15.95 ISBN 0-691-01941-X Available September 1995

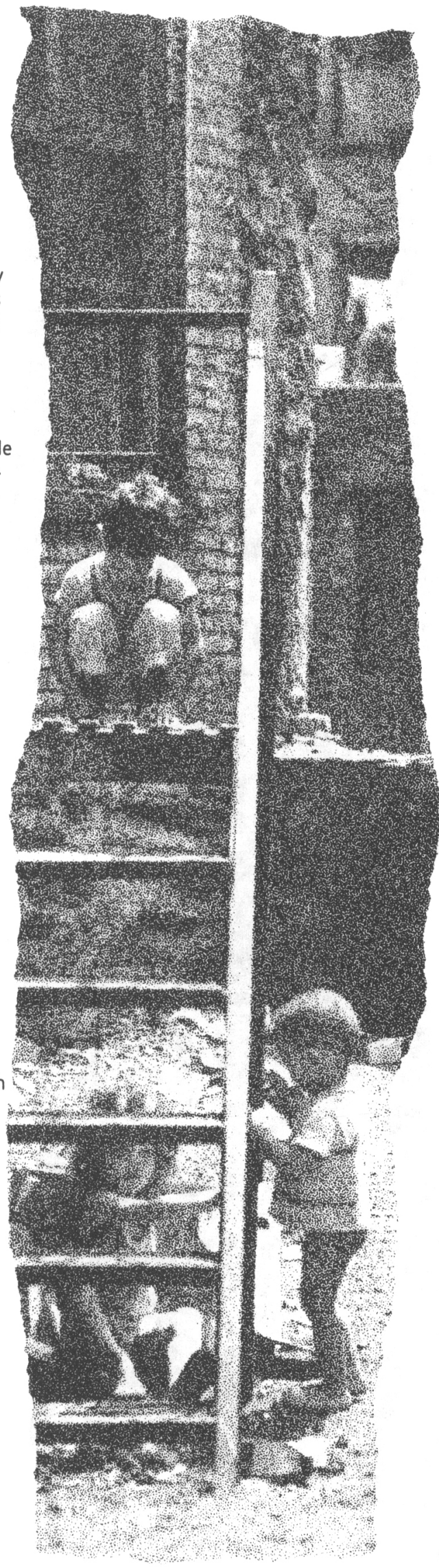

\section{BACK FROM THE FUTURE}

\section{Cuba under Castro \\ Susan Eva Eckstein}

"This important book ... is an ambitious attempt to provide a broad overview of Cuba under the Castro regime. ... It makes for very sober reading that specialists and policymakers should take note of." -Foreign Affairs

". . . a seminal, highly important, wellreasoned, and balanced analysis of Cuba under $C$ astro. The author . . . examines Cuba in a fresh and complex way, marshaling impressive data on Cuban social and economic organization as well as on the inner workings of the revolutionary regime and its internal problems." - Choice

Now in paper: \$15.95 ISBN 0-691-02987-3

Winner of the 1995 Outstanding Book Award from the National Conference of Black Political Scientists

\section{BEHIND THEMULE}

\section{Race and Class \\ in African-American Politics \\ Michael C. Dawson}

"Scholarship, in disciplines and subfields, significantly changes, when mature, inventive, and brilliant works emerge. This book is one such moment and event. It is a pioneering and painstaking exploration of African-American politics from the standpoint of the people in that community, using their opinions, attitudes, and behaviors as guides."-Hanes Walton, Jr.

"Until now, no one has fully probed the contours of black group identity or looked systematically at the tension between solidarity and class differences among African Americans. Michael Dawson has done just that. He combines the best survey, a deep sense of historical and social context, and a vivid realization of why politics matters to show us how much African Americans remain unified, where they are dividing, and how racial group interests deeply affect all Americans. "-Jennifer Hochschild Now in paper: \$14.95 ISBN 0-691-02543-6 


\section{PRINCETON UNIVERSITY PRESS}

\section{STRATEGIC CAPITALISM}

Private Business and Public Purpose in Japanese Industrial Finance

\section{Kent E. Calder}

"Who ensured that loans flowed to Japan's winner industries, such as automobiles and consumer electronics? It wasn't brilliant bureaucrats, Mr. Calder argues with considerable force. The book marshals plenty of evidence of how passive and 'regulatory' the Japanese state frequently was, and how powerless its industrial strategists were against bureaucratic, business, and political foes." - Urban C. Lehner,

The Wall Street Journal

"Calder's book is well documented lucid, and convincing - truly a landmark study." - Thomas McNaugher,

The Key Reporter

Now in paper: \$17.95 ISBN 0-691-04475-9

\section{POWER, TRADE, AND WAR}

\section{Edward D. Mansfield}

"A book that makes major contributions to a political-economy approach to theorizing and analyzing international relations. ... Mansfield's research is exemplary and thought-provoking. . . [It] generates a number of important findings. ..."-Janice E. Thomson, The Annals of the American Academy of Political and Social Science

"The arrogance of power? World peace through world trade? These and similar questions on the relationships among power concentration, trade, and war are examined in this sophisticated quantitative study of the world system in the last two centuries."-Choice Now in paper: \$17.95 ISBN 0-691-04482-

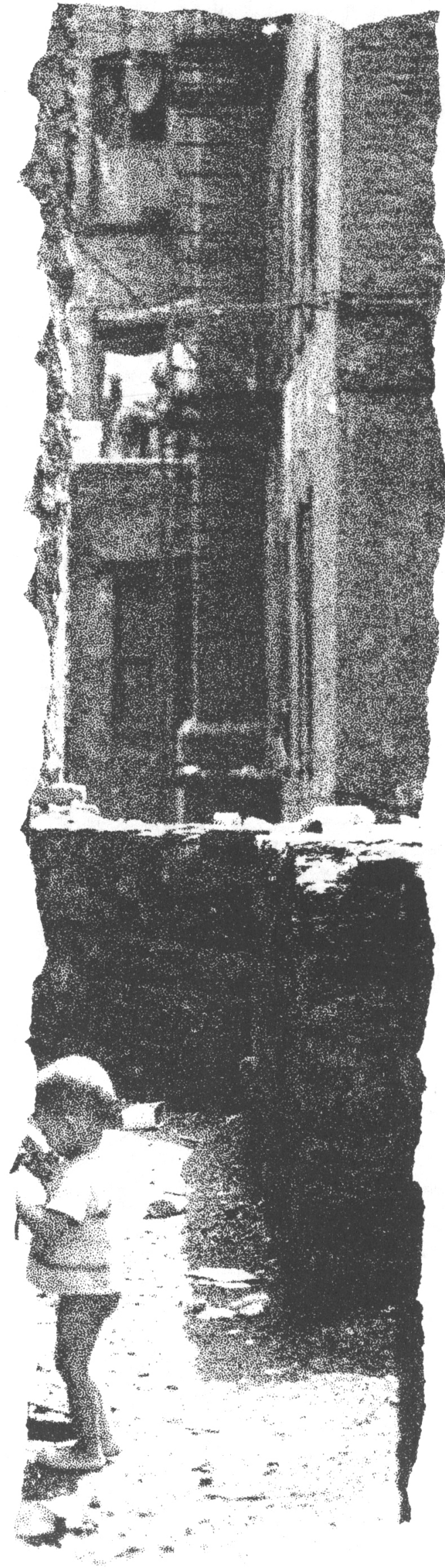

\section{ALLIES, ADVERSARIES, AND INTERNATIONAL TRADE}

\section{Joanne Gowa}

"In uniting the fields of international security and political economy, this superb book succeeds where many others have failed. Quantitative and qualitative tests give empirical bite to its spare theoretical formulation. A reader's dream, this book is both thin and big." - Peter J. Katzenstein

"An outstanding and original book. Arguing that the security externalities created through international exchange affect the willingness of countries to adopt free trade, Gowa opens up an important new avenue of the political economy of trade policy."

-David A. Lake

Now in paper: \$14.95 ISBN 0-691-04471-6 Available September 1995

\section{THE IDEA OF CIVIL SOCIETY}

\section{Adam B. Seligman}

"One of the merits of Adam

Seligman's wide-ranging, probing, and deeply reflective inquiry into the history and uses of the idea of civil society is that it is concerned explicitly with identifying the ambiguities in its applications to contemporary societies ... . In one aspect Mr. Seligman's book is an exploration of the idea of civil society in all its contemporary and historical ironies and ambiguities, one that is richly learned and subtly reasoned. In another it is a question mark over the very idea of a civil society."

-John Gray,

The New York Times Book Review

Now in paper: \$14.95 ISBN 0-691-01081-1 Available September 1995 


\section{NEW IN PAPERBACK}

Updated and with a new introduction by the author

\section{POLITICAL ORGANIZATIONS}

\section{James Q. Wilson}

A major work by one of America's eminent political scientists, Political Organizations has had a profound impact on how we view the influence of interest groups on policymaking. James Wilson wrote this book to counter two ideas: that popular interests will automatically generate political organizations and that such organizations will faithfully mirror the opinions and interests of their members. Moreover, he demonstrated that the way in which political organizations are created and maintained has a profound impact on the opinions they represent and the tactics they use.

Now available for the first time in paperback, this book has broadened its scope to include recently developed organizations as it addresses many of today's concerns over the power of such groups as special-interest lobbies.

Princeton Studies in American Politics Ira Katznelson, Martin Shefter, and Theda Skocpol, Editors Now in paper: \$14.95 ISBN 0-691-04385-X Available September 1995

\section{ADAM SMITH INHIS TIMEAND OURS}

\section{Designing the Decent Society}

\section{Jerry Z. Muller}

"Muller's great accomplishment in this book is to present a clear, thoughtful, and engaging overview of Adam Smith's thought. He reveals Smith to be a wide-ranging and innovative thinker who formulated a comprehensive social science."-Peter McNamara, The Review of Politics

"Jerry Muller has written an extraordinarily good book on the most quoted and least read of the worldly philosophers." -Robert Heilbroner

Now in paper: \$14.95 ISBN 0-691-00161-8 Available September 1995

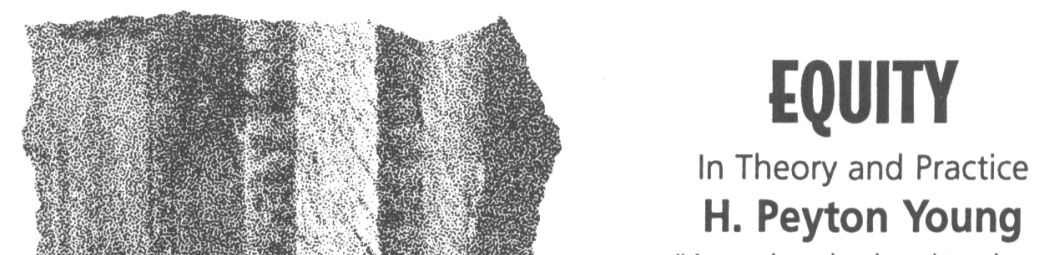

"A concise, clearly written introduction to the alternative principles of equity in practical and topical contexts."-Robert E. Kuenne, The Southern Economic Journal

"Young has written an exciting book on the question of who gets what in contemporary society, and whether such outcomes are fair. Students of social justice throughout the social sciences and philosophy will learn much from this book." -Nathan Keyfitz

Published in association with the Russell Sage Foundation Now in paper: \$17.95 ISBN 0-691-04464-3 Available September 1995

\section{With a new preface by the author \\ LIBERAL NATIONALISM}

\section{Yael Tamir}

"Tamir constructs a philosophical ideal of nationalism, but in leading the reader to questions [of practical importance], she also performs a valuable service for those who try to understand its reality. "-Liah Greenfeld, American Political Science Review

"Yael Tamir has made an important theoretical contribution to a crucial debate that should interest anyone trying to come to terms with contemporary politics. It is a mark of her achievement that one finishes the book willing to credit the non-oxymoronic nature of the term 'liberal nationalism' and, thus, to accept the possibility that [one is not forced] to choose between these." -Sanford Levinson, Ethics

Studies in Moral, Political, and Legal Philosophy Marshall Cohen, Editor

Now in paper: \$13.95 ISBN 0-691-00174-X 


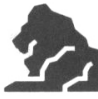 \\ LYNNE RIENNER PUBLISHERS}

\section{Leading the way ...}

\section{in Political Science}

\section{Creating}

Boundaries:

The Politics of Race

and Nation

Kathryn A. Manzo

Takes issue convincingly with

common conceptions about the

relationship - or lack of relation-

ship-between race and nation-

alism.

Forthcoming in January 1996

\section{Now available-}

Politics in the 2nd edition!

\section{Developing}

Countries:

Comparing Experiences

with Democracy

edited by Larry Diamond,

Juan Linz, and Seymour

Martin Lipset

"Brilliantly synthesizes various difficult topics in comparative political development and

democracy." - Choice

paper $\$ 19.95$

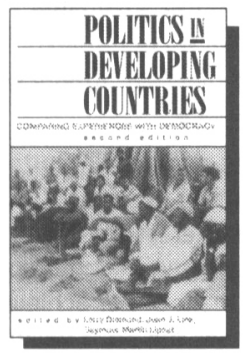

Discourses of Global Politics: A Critical

(Re)Introduction to International Relations Jim George

"A provocative book which ought to be widely-used in courses and frequently-cited in future debates."

- Australian Journal of Political Science cloth $\$ 45 \bullet$ paper $\$ 18.95$

\section{Gender Is Not a Synonym for Women \\ Terrell Carver}

Forthcoming in December 1995 Gender and Political Theory: New Contexts

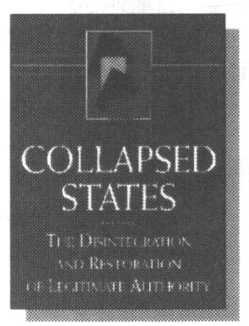

\section{Collapsed States:}

The Disintegration and Restoration of Legitimate Authority edited by I. William Zartman "Provides an excellent sense of the challenges the 'sea changes' of recent years have presented both for the less-developed world and for scholars seeking to understand it."

-The Journal of Politics

cloth $\$ 49.95 \bullet$ paper $\$ 22$

\section{Ever Closer Union?}

An Introduction to

the European

Community

\section{Desmond Dinan}

"A tour de force grounded in the politics of the EU's big players." -Times Education Supplement cloth $\$ 55 \bullet$ paper $\$ 19.95$

\section{Gender and Third World Politics}

Georgina Waylen

Forthcoming in February 1996 Issues in Third World Politics

\section{Buying Power:}

The Political Economy of Japanese Foreign Aid David Arase

"Utterly original.... An outstanding example of what makes the field of modern Japanese political economy so intellectually stimulating."-Chalmers Johnson cloth $\$ 49.95$

\section{2nd edition}

\section{U.S. National}

\section{Security:}

Policymakers, Processes, and Politics

Sam C. Sarkesian

"[Sarkesian] takes us through the process and the institutions briefly, clearly, logically... A most thoughtful and enlightening presentation."

-International Affairs • paper $\$ 19.95$

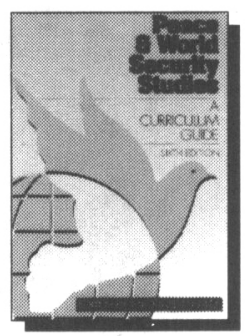

Peace and World Security Studies: A Curriculum Guide 6th Edition

edited by Michael T. Klare

"Provides unsurpassed resources for teachers, and it ought to be on the shelf of anyone who teaches peace studies.... I imagine my copy getting worn, stained, and dog-eared in fairly short order and remaining in active use long after."

-Peace \& Change • paper $\$ 22$

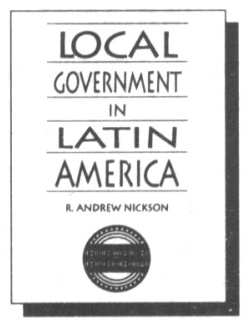

Local Government in Latin America

R. Andrew Nickson

"This will stand as the definitive reference work on the subject for years to come." -Jonathan Fox cloth $\$ 49.95$

\section{Gender and}

Development:

Rethinking

Modernization and

Dependency Theory

Catherine V. Scott

"Essential reading." - Choice cloth $\$ 35$

\section{Dictionary of Alternative Defense} Bjørn Møller

An important reference tool with over 550 detailed entries, an introduction and history of alternative defense, the status of current ideas and concepts, and a rich bibliography. cloth $\$ 75$

\section{Political}

Liberalization and Democratization in the Arab World: Volume 1, Theoretical Perspectives edited by Rex Brynen, Baghat Korany, and Paul Noble cloth $\$ 55 \bullet$ paper $\$ 23.95$ 


\section{America/Américas}

Myth in the Making of U.S. Policy Toward Latin America

\section{ELDON KENWORTHY}

"Kenworthy's first-rate study of Reagan's policies in Nicaragua reminds us that even when the emperor has no clothes he remains well wrapped in myth and deception. Equally persuasively, America/Américas argues that these policies were rooted in a misleading view of the hemisphere that was firmly established before the Cold War and continues to dominate Washington's thinking today."-Richard Fagen

206 pages 7 illus.

cloth: $\$ 35.00$ paper: $\$ 14.95$

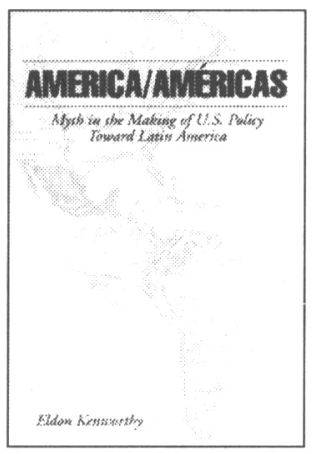

\section{Inside the Kremlin During the Yom Kippur War}

\section{VICTOR ISRAELYAN}

"Not since Leon Trotsky's writings in the 1930s has a witness to the foreign policymaking decision process of the Communist Party's top leadership provided us with so substantive a work." -from the Foreword by Alvin Z. Rubinstein 248 pages 12 illus. $\$ 29.95$ October

\section{From the Polish Underground}

Selections from Krytyka, 1978-1993

EDITED BY MICHAEL BERNHARD AND HENRYK SZLAJFER

"This collection of writings from Krytyka is much needed and highly welcome. It will provide an indispensable source for virtually anybody who, as a scholar, political analyst, journalist, teacher, student, or just general reader, wishes to gain insight into the extremely complex matter of the emerging new political thought in the countries of the former East Bloc."-Stanislaw Baranczak 496 pages cloth: $\$ 75.00$ paper: $\$ 19.95$

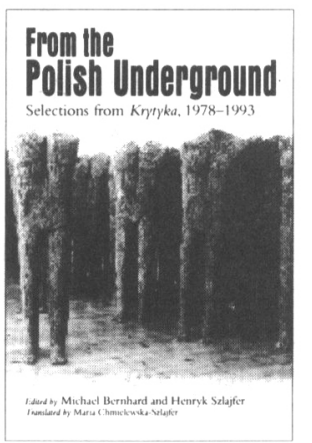

\section{Ayn Rand}

The Russian Radical

\section{CHRIS MATTHEW SCIABARRA}

"Ayn Rand, a radical? A comrade of Marx, methodologically speaking? Libertarians and Marxists BEWARE, because Sciabarra makes a solid case for his astounding claim. An eye-opening work, and a pleasure to read!"-Bertell Ollman

490 pages 17 illus. cloth: $\$ 55.00$ paper: $\$ 18.95$

\section{Socialism After Communism}

The New Market Socialism

\section{CHRISTOPHER PIERSON}

"A compulsively readable as well as persuasive book [that] advances the level of theoretical discussion thoroughly and commendably."-Paul Thomas

260 pages cloth: $\$ 45.00$ paper: $\$ 16.95$

For sale in US \& Canada only

\section{On Humane Governance}

Toward a New Global Politics

\section{RICHARD FALK}

A visionary account of the potential for global governance in the new world order, written for the Global Civilization Project of the World Order Models Project (WOMP). 280 pages cloth: $\$ 45.00$ paper: $\$ 16.95$

For sale in US \& Canada only

\section{Moral Voices, Moral Selves}

Carol Gilligan and Feminist

Moral Theory

SUSAN J. HEKMAN

"An original analysis of Gilligan's importance and a valuable extension and application of her work to feminist ethics." -Nancy Love moral voices moral selves

210 pages cloth: $\$ 40.00$ paper: $\$ 16.95$

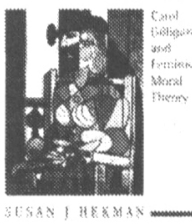
For sale in US \& Canada only

Re-Reading the Canon

\section{Feminist Interpretations of Simone de Beauvoir}

\section{EDITED BY MARGARET A. SIMONS}

Essays that reinterpret Simone de Beauvoir's relationship to existentialism and the problem of her relationship to feminism. 336 pages cloth: $\$ 45.00$ paper: $\$ 16.95$

\section{Feminist Interpretations of Hannah Arendt}

EDITED BY BONNIE HONIG

The first collection of feminist engagements with Hannah Arendt's political thought.

400 pages cloth: $\$ 55.00$ paper: $\$ 18.95$

\section{PENN STATE PRESS}

820 North University Drive University Park, PA 16802-1003

MasterCard/VISA orders: 1-800-326-9180 


\section{Democracy in Latin America Patterns and Cycles}

Edited by Roderic Ai Camp, Tulane University

Recent events, such as the signing of the North American Free Trade Agreement, have made it imperative for students, scholars, and policymakers to grasp the history and possible directions of Latin American political change. Democracy and Development brings together the most important and up-todate scholarship on this crucial topic.

Edited and introduced by one of the foremost political scientists studying the region, Democracy and Development provides thirteen essays that examine the problems posed by political development in the form of democratization. The essays are arranged in four sections: "What Is Democratization in Latin America?" "The Political Heritage-Culture, Structures, and Authoritarianism," "Agents of Political Change? Religion, Militarism, Electioneering, and Nongovernmental Organizations," and "Consequences of Democratization: Case Studies in Change."

Available Oct. 1995296 pp. with reading list Cloth $\$ 40.00$ Paper $\$ 14.95$

\section{Lives at Risk}

\section{Hostages and Victims in American Foreign Policy \\ by Russell D. Buhite, University of Tennessee}

"A timely work that is a must read for Americans in general and policymakers in particular." - Howard Jones, University of Alabama

Lives at Risk is the first book that provides the historical context needed to understand terrorism and America's responses to terrorist acts. Historian Russell D. Buhite here examines key instances of hostage-taking throughout U.S. history, from the late eighteenth century to the 1980s, and shows how previous experiences can help us deal with terrorist threats today.

Bringing to the study of terrorism his renowned understanding of U.S. foreign policy, Buhite has created a work that deftly combines lively narrative and practical recommendations. As Americans continue to be the focus of terrorist acts, Lives at Risk will be a valuable work for anyone interested in the best way to avert future crises.

1995 (available now) 304 pp. with maps, ills., bib., index Cloth $\$ 45.00$ Paper $\$ 17.95$

\section{Biotechnology in Latin America Politics, Impacts, and Risks}

Edited by N. Patrick Peritore and Ana Karina GalvePeritore, University of Missouri-Columbia

"This timely and important collection of essays will be of great utility to policymakers, teachers,

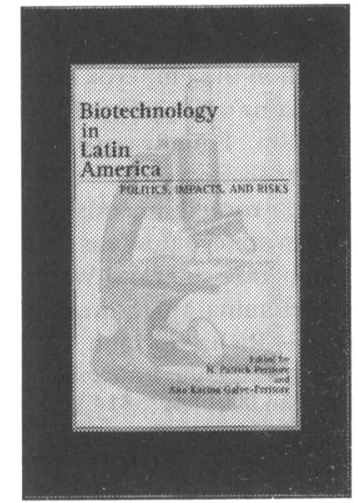
and the interested public....

Peritore's outstanding introductory essay... is worth the price of the book." -Elinor G. K. Melville, York University (Canada)

From synthetic growth hormones to genetic therapies for inherited diseases, biotechnology offers tremendous opportunities and incalculable risks. Nowhere are the challenges posed by the new science more keenly felt than in Latin America, where vast and varied amounts of genetic material have already drawn the attention of transnational corporations.

Biotechnology in Latin America examines this perilous situation, shedding light on how biotechnology can be made to serve developing nations rather than provide yet another route for exploitation by first-world industry. The editors of this volume have brought together new essays by political scientists, biologists, sociologists, and other authorities. Topics include the significance of Latin America for the industry of genetic engineering, the government and corporate powers promoting biotechnology, and case studies of attempts to exploit the new science in Mexico, Cuba, and Colombia.

1995 (available now) 229 pp. with bib., gloss. Cloth $\$ 45.00$ Paper $\$ 16.95$

To order, contact:

\section{SR Books}

104 Greenhill Avenue • Wilmington DE 19805-1897

Call toll-free 800-772-8937

Outside the U.S., call 302-654-7713

FAX 302-654-3871 • Internet scholres@ssnet.com

Examination copies of these and other SR Books are available for appropriate course instructors-please call for details. 


\section{POLITICAL ISSUES}

MICHAEL KIDRON AND RONALD SEGAL

THE STATE OF THE WORLD ATLAS, Fifth Edition

"Unique and uniquely beautiful...A single map here tells us more about the world today than a dozen statistical abstracts or scholarly tomes." The Los Angeles Times. "These are the bad dreams of the modern world, given color and shape and submitted to a grid that can be grasped instantaneously."-The New York Times. Combining 50 all-new colorful maps, graphs and text, this updated edition of the Atlas makes true sense of our rapidly changing world by incorporating vital human data about the changing political and economic face of our globe. 50 full-color maps. $160 \mathrm{pp}$.

Viking hardcover

0-670-86545-1

$\$ 29.95$

Penguin paperback

$\$ 16.95$

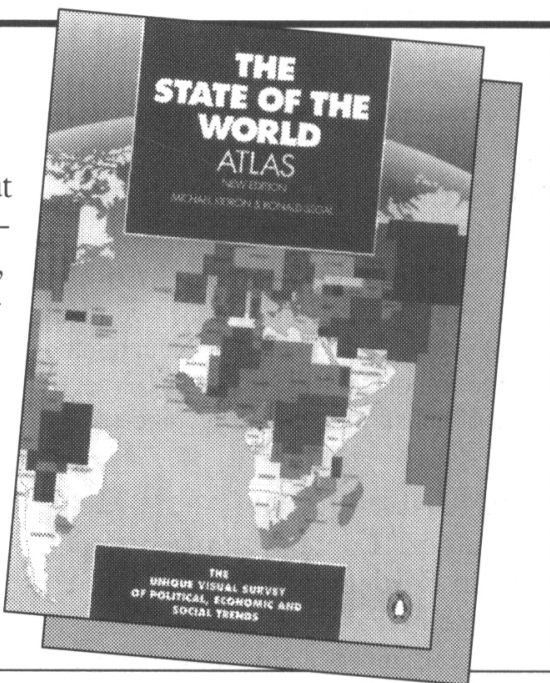

\section{DARRELL DELAMAIDE}

\section{THE NEW}

\section{SUPERREGIONS OF EUROPE}

"Delamaide's masterly, indispensable analysis of the emergent superregions is vital to understanding what's really happening in Europe."--Robert Heller. "A powerful and well-crafted analysis of major changes now reconfiguring Europe's economic landscape."-USA Today. $336 \mathrm{pp}$.

Plume paperback $\quad$ 0-452-27255-6 \$12.95

JOSEPH E. PERSICO

\section{NUREMBERG}

\section{Infarmy on Trial}

"Fascinating....Persico has vividly recreated in human terms the drama, the agony, and the triumph of one of the seminal events in modern history."-Henry A. Kissinger. Photographs. 544 pp.

Penguin paperback 0-14016622-X

$\$ 14.95$

GEORGE D. MOFFETT III, PH.D.

\section{CRITICAL MASSES}

The Global Population

\section{Crisis into the 21st Century}

"A thoughtful, evenhanded, and accessible mix of reporting and analysis concerning population control. Should aid anybody engaged with this vital issue."--Kirkus Reviews. $368 \mathrm{pp}$.

Penguin paperback 0-14023226-5

Available November 1995

\section{W. J. F. JENNER}

\section{THE TYRANNY OF HISTORY The Roots of China's Crisis}

"It has given me a better understanding of China than almost any other book I have read on the subject. Everyone concerned with the future of China ought to read it."-James Callaghan. 272 pp.

Penguin paperback 0-14-014677-6

$\$ 12.95$

\section{BRIAN HALI}

\section{THE IMPOSSIBLE COUNTRY}

\section{A Journey Through the Last Days of Yugoslavia}

"Hall lays out the naivete, the collective insecurity, the paranoia and the plain foolishness that made war in Yugoslavia possible. He writes beautifully, but most of all he writes intelligently, pinpointing the historical meaning in all he hears and sees." - Washington Post Book World. $352 \mathrm{pp}$.

Penguin paperback 0-140249230

$\$ 11.95$

\section{AVI SHLAIM}

\section{WAR AND PEACE}

\section{IN THE MIDDLE EAST}

\section{A Critique of American Policy}

"Breathtaking in its scope and precision ...provides an unusually lucid historical analysis of the Middle East."Library Journal. "Concise, passionately argued."-Kirkus Reviews. 160 pp.

Penguin paperback 0-14-024564-2 \$9.95 


\section{Politics Around the Globe}

YugoslaVia's Bloody Collapse

Causes, Course, and Consequences

Christopher Bennett

"This is an absolutely excellent must-read study of the collapse of Yugoslavia...It overflows with fresh insight and clarity on each page."

-Library Journal

0-9147-1234-7 / \$24.95 cloth

\section{To Secure These Rights}

Scott Douglas Gerber

With a Foreword by Henry J.Abraham

Concentrating specifically on the two fundamental documents

of American government, the Declaration of Independence and the Constitution of the United States, Gerber articulates a systematic theory of constitutional interpretation.

0-8147-3066-3 / \$45.00 cloth

\section{Communism's Collapse, Democracy's Demise?}

The Cultural Context and Consequences of the East German Revolution

Laurence McFalls

Offers a full understanding of communism's collapse, providing an explanation for the cultural conflicts and the identity crisis that have afflicted Germany since reunification.

$0-8147-5521-6 / \$ 40.00$ cloth

\section{The Global Expansion of Judicial Power}

Edited by $\mathrm{C}$. Neal Tate and Torbjörn Vallinder

"Assesses and analyzes trenchantly and sophisticatedly a

cascading development that is as significant and fascinating as it

is controversial and durational."

- Henry J. Abraham, University of Virginia

0-8147-8209-4 / \$45.00 cloth

\section{Political Protest and Social Change}

Analyzing Politics

Charles F. Andrain and David E. Apter

Analyzes the reciprocal impact of cultural beliefs, sociopolitical structures, and individual behaviors on protests throughout the world. 0-8147-0634-7 / \$19.95 paper • 0-8147-0630-4 / \$50.00 cloth

\section{The Mitterrand Era}

Policy Alternatives and Political Mobilization in France

Edited by Anthony Daley

$0-8147-1872-8 / \$ 50.00$ cloth

\section{Comparative}

\section{CONSTITUTIONAL}

\section{ENGINEERING}

An Inquiry into Structures,

Incentives, and Outcomes

Giovanni Sartori

Examines in detail the variant

forms of democratic govern-

ment and reconceives constitu-

tion making as a system of incentives.

0-8147-8002-4/\$18.50 paper anism, liberalism, and

\section{NEW IN PAPERBACK}

\section{Democratic}

\section{Community}

Nomos XXXV

Edited by John W. Chapman

and lan Shapiro

"A state-of-the-art meditation on relations, theoretical and practical, among a familiar triad of themes: communitaridemocracy."

- APSR

\section{EXTREMISM IN AMERICA}

A Reader

Edited by Lyman Tower Sargent

Painting a vivid portrait of life on the political fringe, this collection presents the writings of extremist groups and individuals, including William L. Pierce, the Ku Klux Klan, the Aryan Nation, Phyllis

Schlafly, and the Left Green Network.

0-8147-8011-3 / \$17.95 paper • 0-8147-7978-6 / \$55.00 cloth

\section{POWER IN STRUGgLe}

Feminism, Sexuality and the State

Davina Cooper

Explores the relationship between power, sexuality, and the state. 0-8147-1527-3 / \$17.95 paper • 0-8147-1526-5 / \$55.00 cloth

\section{Politics After Hitler}

The Western Allies and the German Party System

Daniel E. Rogers

The first book to demonstrate the importance of America, Britain, and France in the development of party politics in Germany after 1945. $0-8147-7461-\mathrm{X} / \$ 40.00$ cloth

\section{INTERNATIONAL THEORY \\ Critical Investigations \\ Edited by James Der Derian \\ With a Foreword by Adam Watson}

This collection begins where classical realists began, with "diplomatic investigations" into the limits and possibilities of international theory. $0-8147-1862-0 / \$ 17.50$ paper $\bullet 0-8147-1861-2 / \$ 50.00$ cloth

\section{The Social Construction of Democracy}

Edited by George Reid Andrews and Herrick Chapman

Explores why democracies have succeeded and failed over

the past 100 years in a range of national settings.

0-8147-1508-7 / \$40.00 cloth

\section{Theory and Practice \\ Nomos XXXVII}

Edited by lan Shapiro and Judith Wagner DeCew

Explores the relationship between philosophical theories and everyday life.

0-8147-8003-2 / \$42.50 cloth

\section{American Republicanism}

Roman Ideology in the United States Constitution

M. N. S. Sellers

0-8147-8005-9 / \$45.00 cloth

\section{0-8147-1499-4/ $\$ 17.50$ paper \\ $\overline{\overline{I n}}$ New YORK UNIVERsITY PRESS • 70 Washington Square South • New York, NY 10012 To order, call 1-800-996-NYUP (6987)}


"An excellent introduction to the debate about poverty in America."

-Lawrence M. Mead

Author of The New Politics of Poverty

"A thoughtful analysis of one of America's most vexing social problems. [Kelso] eschews the platitudes of both left and right to examine the intractable nature of poverty and its diverse causes. He is especially insightful in his dissection of the role culture plays in poverty-and for the concern government should have for the character of its citizens."

-Linda Chavez

Author of Out of the Barrio: Toward a New Politics of Hispanic Assimilation

In this timely work, William A. Kelso analyzes how the persistence of poverty has reversed liberal and conservative positions during the last 30 years, and suggests that the arguments of both sides are misguided. Offering new explanations for the persistence of poverty, Kelso looks beyond familiar labels such as "underclass" and "family values" to analyze poverty not as a monolithic condition, but as a multidimensional problem.

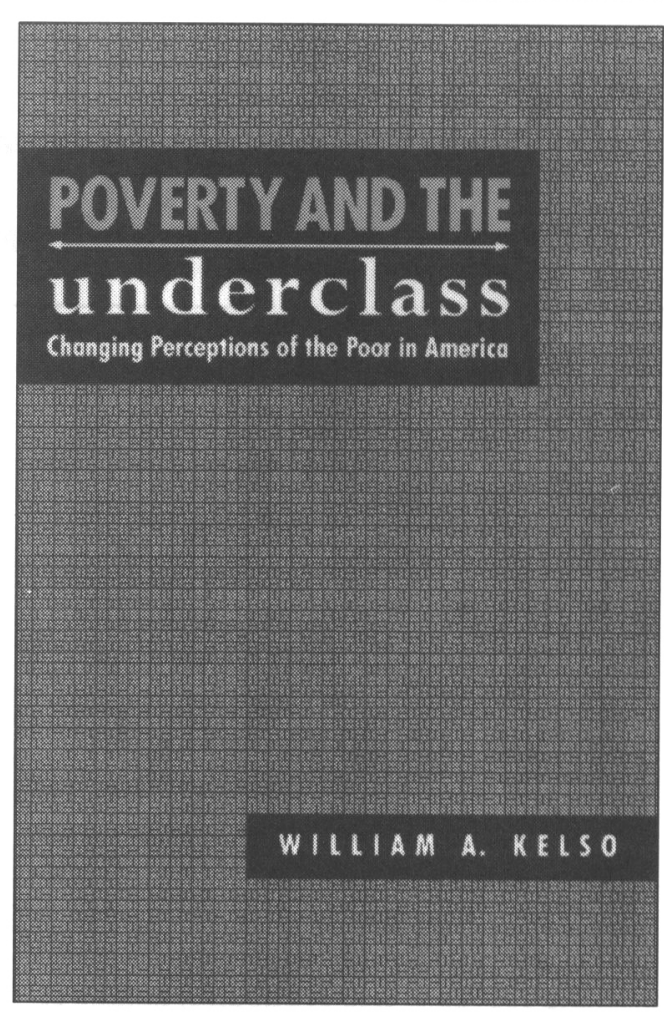

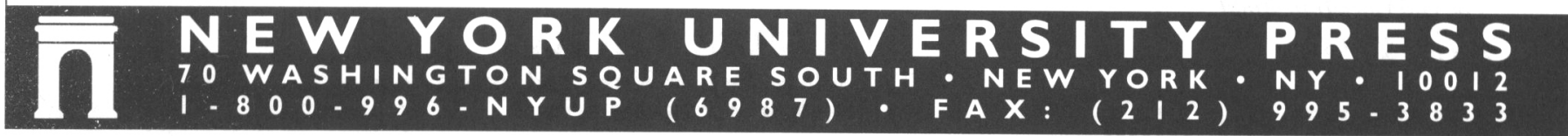

\section{New from SUNYPress \\ Racism in the Post-Civil Rights Era Now You See It, Now You Don't Robert C. Smith}

"In this insightful book, Smith has no reservations about using the ' $R$ ' word (racism) as the most accurate label for the still extensive system of white-generated oppression facing AfricanAmericans.... He provides an outright refutation of the notion, omnipresent in scholarly and journalistic writing over the last decade, of a 'declining significance of race' in the United States." - Joe R. Feagin, Graduate Research Professor, University of Florida

217 pages $\bullet \$ 24.50$ hardcover $\bullet 0-7914-2437-5$ state university of New York Press At bookstores or call 1-800-666-2211 Visa, MasterCard, American Express, Discover SUNY Press • c/o CUP Services • PO Box 6525 Ithaca, NY $14851 \bullet$ Add $\$ 3$ shipping New York State residents, add $8 \%$ sales tax
This is the first book to assess in a systematic and theoretically informed way the course and status of racism in the post-civil rights era. It convincingly demonstrates that racism continues to exist in contemporary American society twenty-five years after the civil rights revolution.

Smith clarifies the concept of racism through a historical analysis of the doctrine and practice of white supremacy. Then, drawing on a variety of data-surveys, court cases, the academic literature, government and privately collected statistical reports and studies, and personal experiences-Smith traces the presentday manifestations of racism ideologically, attitudinally, behaviorally, and institutionally. The final chapter presents a detailed critique of the literature on the black underclass and of William Julius Wilson's thesis on the declining significance of racism in explaining the underclass. In the process, it presents a persuasive argument that the persistence and growth of the underclass is itself major evidence of the prevalence of racism today. 


\section{Re(N POLITICAL perspectives}

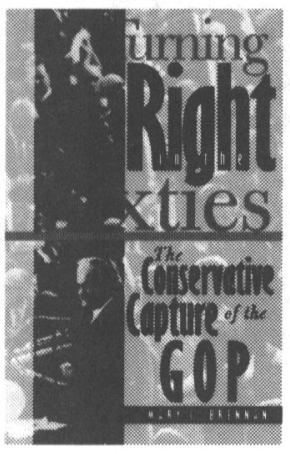

Turning

Right

in the

Sixties

The Conservative

Capture of the GOP

MARY C. BRENNAN

A look at the conser-

vative wing of the

Republican Party and

its successful attempts to reinvent itself and gain control of the GOP during the 1960s. "Essential reading for anyone who wants to understand the politics of the 1990s." - Leo P. Ribuffo, author of The Old Christian Right 224 pp., $\$ 29.95$

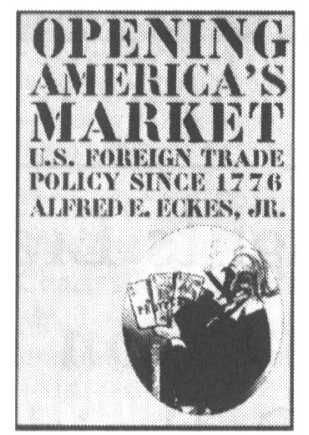

Opening America's Market

U.S. Foreign Trade

Policy since 1776

ALFRED E. ECKES, JR.

"The most lucid,

insightful, and

complete analysis

of U.S. foreign trade

policy on the market. . . An instant classic, one that is indispensable for anyone interested in U.S. trade policy."

- Pat Choate, Manufacturing Policy

Project

424 pp., \$34.95 Business, Society, $e^{2}$ the State

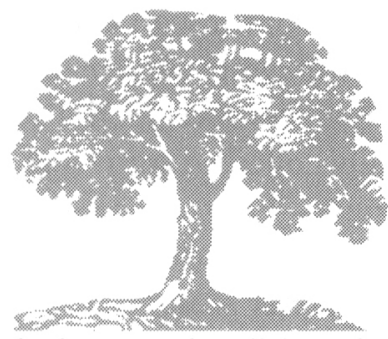

at bookstores or by toll-free order

\section{America's Secret War against Bolshevism}

U.S. Intervention in the Russian Civil War, 1917-1920

DAVID S. FOGLESONG

An exploration of the origins of American anti-Bolshevism and a revealing look at the covert operations undertaken by the Wilson administration in its opposition to Bolshevik activity.

approx. 460 pp., $\$ 45$

\section{A License to Steal}

The Forfeiture of Property

LEONARD W. LEVY

“The book displays both Levy's capacity for exhaustive and discriminating scholarship and his penchant for incisive political critique." - Stanley Katz, American Council of Learned Societies approx. 230 pp., \$29.95 • available January'96

\section{Legislating Privacy}

Technology, Social Values, and Public Policy PRISCILLA M. REGAN

"The first political-science analysis of privacy-protection politics in the United States over the past three decades... . Regan has brightly illuminated contemporary political contests over new-technology threats to privacy and efforts (both successful and unsuccessful) at enacting new privacy protections."

- Alan F. Westin, Columbia University

332 pp., $\$ 34.95$

\section{The Greening of Protestant Thought} ROBERT BOOTH FOWLER

Explores the theological, political, and policy debates within U.S. Protestant thought from 1970 to 1990 concerning the environment and environmental crises.

approx. 260 pp., \$34.95 cloth, \$14.95 paper

\section{Elections and Democracy in Central America, Revisited}

New and Enlarged Edition EDITED BY MITCHELL A. SELIGSON AND JOHN A. BOOTH

An expanded and reworked edition of Elections and Democracy in Central America (1989), these essays reevaluate the status of democratization in Costa Rica, Honduras, El Salvador, Guatemala, Nicaragua, and Panama. approx. 350 pp., \$39.95 clotb, \$16.95 paper

\section{the university}




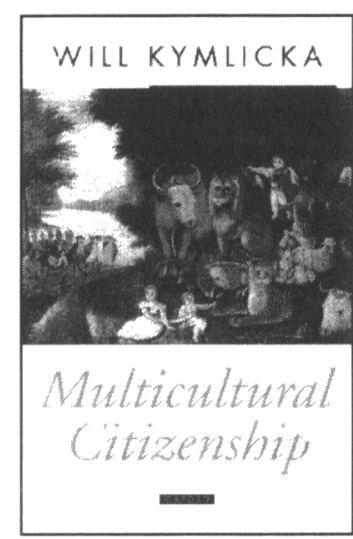

\section{Multicultural Citizenship}

A Liberal Theory of Minority Rights WILL KYMLICKA

The increasingly multicultural fabric of modern societies has given rise to many new issues and conflicts, as ethnic and national minorities demand recognition and support for their cultural identity. This book presents a new conception of the rights and status of minority cultures.

(Oxford Political Theory)

1995296 pp. \$29.95

\section{Green Globe Yearbook of International Co-operation on Environment and} Development 1995

EDITED BY HELGE OLE BERGESEN

AND GEORG PARMANN

Praise for previous editions:

"Likely to become indispensable."

-Earth Summit Times.

"The Green Globe Yearbook is a most valuable addition to the international league of references in environment and development."-New Scientist.

1995320 pp. $\$ 49.95$

\section{Industrial Enterprise and}

\section{European Integration}

From National to International Champions in Western Europe EDITED BY JACK HAYWARD

This volume focuses on how European national champions have fared in an increasingly globalized industrial context. After setting the four national policy contexts of France, Germany, Britain, and Italy, the work compares four major industrial sectors: electricity, aerospace, air transport, and telecommunications.

(Nuffield European Studies)

1995384 pp. $\$ 58.00$

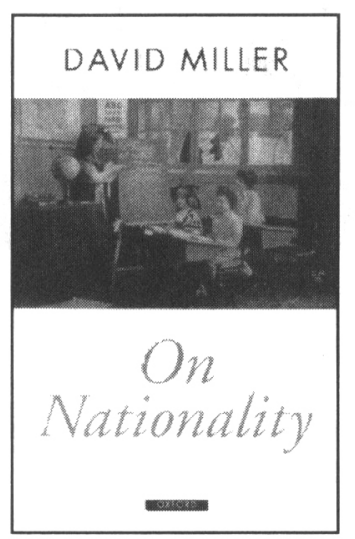

\section{On Nationality}

DAVID MILLER

Here, the author argues that national identities are valid sources of personal identity, that we are justified in recognizing special obligations to our co-nationals, and that nations have good grounds for wanting to be politically self-determining, but that recognizing the claims of nationality does not entail suppressing other sources of personal identity, such as ethnicity.

(Oxford Political Theory)

November 1995168 pp. \$24.95

\section{The European Union and the Regions}

EDITED BY BARRY JONES AND

MICHAEL KEATING

If Europe witnessing the death of the once-mighty nation-state, then two of the most powerful factors in its post-war decline have been European integration and regionalism. This book provides a definitive examination of the new patterns of politics and policy that link the three levels of European Union, nation-state, and region.

1995320 pp. \$59.00

\section{Between Freedom and \\ Subsistence}

China and Human Rights

ANN KENT

"A carefully researched and candidly refreshing exposition of an increasingly intriguing aspect of China's political life...."-Choice.

Set in the context of international human rights law, this is a comprehensive analysis of the theory and practice of human rights in China since 1949.

1994 (paper 1995) 312 pp. paper $\$ \mathbf{2 6 . 0 0}$

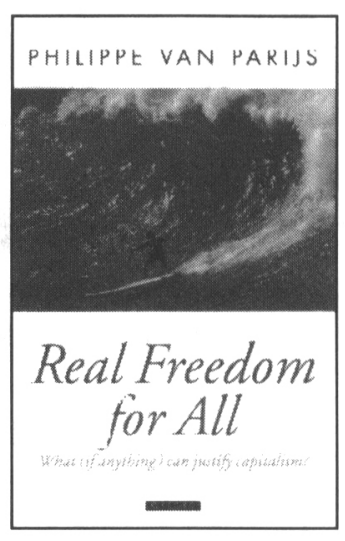

\section{Real Freedom for All}

What (If Anything) Can Justify

Capitalism?

PHILIPPE VAN PARIJS

In this ground-breaking book, Philippe Van Parijs sets out a new and compelling case for a just society. Assessing and rejecting the claims of both socialism and conventional capitalism, he presents a clear and compelling alternative vision of the just society: a capitalist society offering a substantial and unconditional basic income to all its members.

(Oxford Political Theory)

1995344 pp. \$35.00

\section{European Community}

The Building of a Union

Second Edition

JOHN PINDER

Invaluable for all those who seek a greater understanding of the European Community, John Pinder's book gives a complete and coherent view of its formation. He includes recent developments such as the GATT negotiations, the "Delors II" package, the aftermath of Maastricht, and the new bids for membership.

1995272 pp. paper \$16.95

\section{War Without Winners}

Afghanistan's Uncertain Transition After the Cold War

RASUL BAKHSH RAIS

The situation created by the Soviet intervention in Afghanistan attracted world-wide attention, but little effort was made to understand the domestic roots of the confrontation and to explain the links betweeen internal strife and external invasion. In this work, the author analyzes all the factors that led to the Afghan tragedy.

1994300 pp. $\$ 27.00$ 


\section{INTERNATIONAL INSTITUTE FOR STRATEGIC STUDIES}

\section{The Military Balance 1995-1996}

This work provides up-to-date information on the composition, size, and deployment of the world's armed forces. It has established itself as a global database of military strength organization, and defense expenditure. Packed with economic and demographic statistics, it also provides up-to-date analysis of the latest developments in all arms-control fields, details of the mandate and composition of UN and other international peacekeeping roles, and analysis of surface-to-surface missiles, whether armed with nuclear, biological, chemical, or conventional warheads.

\section{The Military Balance 1995-1996 offers:}

- Up-to-date information on the composition, size, and weapons holdings of over 165 countries

\section{-A loose-leaf wall map of the Middle East}

- Economic and demographic statistics together with details of defense expenditure

-The latest developments in all arms-control fields

- Details of the mandate and composition of UN and other international peacekeeping forces

-An analysis of surface-to-surface missiles, whether armed with nuclear, biological, chemical, or conventional warheads

This year's edition only

(ISBN 0-19-828055-6, 256 pp., available November 1995): paper $\mathbf{\$ 6 5 . 0 0}$

Annual Subscription Rate (ISSN 0459-7222; 1 issue) $\mathbf{\$ 5 9 . 0 0}$

\section{Strategic Survey 1994-95}

\author{
"Authoritative...a traditlon of out- \\ spokenness and willingness to \\ challenge conventlonal thinklng...." \\ -The Guardian
}

This outstanding work is an annual analytical review and assessment of security-related events around the world. The significant events of the year are examined in their political contexts, and the trends for international security are identified. The book, consisting of factual accounts, analysis, and background data, is organized both by topic (arms control or strategic policy issues, for example) and geographically, with a careful review of each geographic area.

\section{The contents of Strateglc Survey 1994-1995 Include:}

-Perspectives

-Strategic Policy Issues

-The Americas

- Europe

- The Middle East

-Asia

- Africa

- Chronologies

This year's edition only

(ISBN 0-19-878136-9, 256 pp.): paper $\mathbf{\$ 2 9 . 9 5}$

Annual Subscription Rate

ISSN 0459-7230, 1 issue): $\mathbf{\$ 3 0 . 0 0}$ 


\section{Survival: The IISS Quarterly}

Survival is a leading voice in the field of strategic studies. It challenges conventional wisdom and brings fresh, often controversial, perspectives to bear on the strategic issues of the moment. Under the new editorship of Philip Gordon,Sunival builds on its strong reputation of providing sound analysis, authoritative information and innovative thinking on global issues with important military or security implications, and looks toward the twenty-first century identifying the emerging strategic trends. Case studies are set in the context of broader issues, identifying patterns of behavior and seeking to learn from developments in the increasingly complex world of international security.

\section{Artlcles tackling the following key Issues of the mld-1990s will be featured:}

- The non-military dimensions of security

- Nuclear proliferation and the new nature of deterrence

-Peacekeeping and peaceenforcement

- Stability in Russia and China

-The future of US global engagement

- The changing geopolitics of the Middle East

Survival is available by subscription only. Annual Subscription Rate (ISSN 0039-6338, 4 issues): $\$ 54.00$

\section{The Adelphi Papers}

The Adelphi Paper series analyzes current and future issues of international security and provides essential reading for students of international relations and all those wishing to broaden their understanding of world security developments. Taken together, the annual Adelphi "library" of eight to ten titles constitutes the best comprehensive analysis of worldwide strategic issues available in monograph form.

Annual Subscription Rate

(ISSN 0567-932X, approximately 10 papers): $\mathbf{\$ 1 3 9 . 0 0}$

\section{Titles In the Adelphi Papers series are also avallable separately:}

India Redefines its Role SHEKHAR GUPTA

1995 ISBN 0-19-828021-1 paper $\mathbf{\$ 1 7 . 9 5}$

Multinational Military Forces: Problems and Prospects

ROGER H. PALIN

1995 ISBN 0-19-828025-4 paper $\mathbf{\$ 2 3 . 0 0}$

Towards a New Balance of Power in Asia PAUL DIBB

1995 ISBN 0-19-828069-6 paper $\mathbf{\$ 2 3 . 0 0}$

The Crisis of the Iranian State

AHMED HASHIM

1995 ISBN 0-19-828023-8 paper $\$ 23.00$

Indochina

CARLYLE THAYER

1995 ISBN 0-19-828024-6 paper $\$ 23.00$

\section{Forthcoming:}

International Law and the Use of Force MARC WELLER

1995 ISBN 0-19-828056-4 paper $\$ 23.00$

Disarmament and Demobilisation After Civil Wars

MATS BERDAL

1995 ISBN 0-19-828026-2 paper $\$ 23.00$

Liberal Democracy and International Order ROLAND DANNREUTHER

1995 ISBN 0-19-828020-3 paper $\$ 23.00$ 


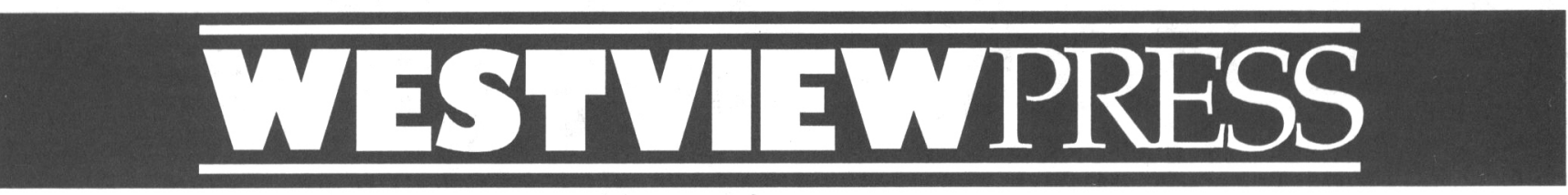

\begin{tabular}{|c|}
\hline Dilemmas in \\
American Politics \\
L. Sandy Maisel, series editor \\
Remote and Controlled \\
Media Politics in a Cynical Age \\
Matthew Robert Kerbel \\
170 pages $\bullet \$ 45.00$ hc $\bullet \$ 13.95 \mathrm{pb}$ \\
"Can We All Get Along?" \\
Racial and Ethnic Minorities \\
in American Politics \\
Paula D. McClain \\
and Joseph Stewart, Jr. \\
201 pages $\bullet \$ 45.00$ hc $\bullet \$ 13.95 \mathrm{pb}$ \\
\hline
\end{tabular}

\section{Green Planet Blues}

Environmental Politics from Stockholm to Rio edited by Ken Conca, Michael Alberty, and Geoffrey Dabelko 326 pages $\bullet \$ 64.95 \mathrm{hc} \bullet \$ 22.95 \mathrm{pb}$

\section{Religion and Politics in America}

Faith, Culture, and Strategic Choices

Robert Booth Fowler

and Allen D. Hertzke

Oct. $1995 \bullet 264$ pages $\bullet \$ 48.50 \mathrm{hc} \bullet \$ 18.95 \mathrm{pb}$

\section{International Relations in a Changing Global}

\section{System}

Toward a Theory of World Polity, Second Edition

\section{Seyom Brown}

Nov. $1995 \bullet 168$ pages $\bullet \$ 49.95 \mathrm{hc} \bullet \$ 17.95 \mathrm{pb}$

\section{Beyond Separateness}

The Social Nature of

Human Beings-Their Autonomy,

Knowledge, and Power

Richard Schmitt

204 pages $\bullet \$ 48.50 \mathrm{hc} \bullet \$ 14.95 \mathrm{pb}$

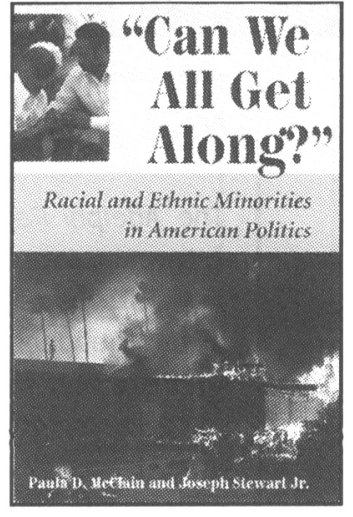

\section{The United Nations} in the Post-Cold War Era

Karen A. Mingst

and Margaret P. Karns

192 pages $\bullet \$ 49.95 \mathrm{hc} \bullet \$ 13.95 \mathrm{pb}$

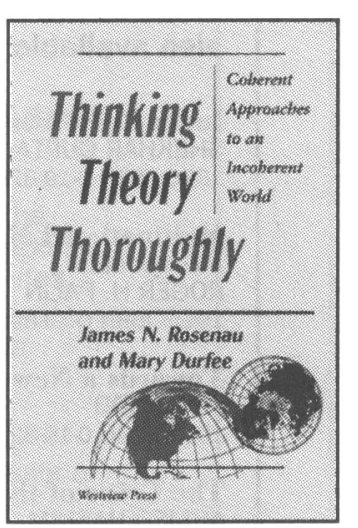

\section{Thinking Theory \\ Thoroughly}

Coherent Approaches to an Incoherent World

James N. Rosenau and Mary Durfee

218 pages $\bullet \$ 45.00 \mathrm{hc} \bullet \$ 14.95 \mathrm{pb}$

\section{Mercy Under Fire}

War and the Global Humanitarian Community

Larry Minear

and Thomas G. Weiss

260 pages $\bullet \$ 59.95 \mathrm{hc} \bullet \$ 18.95 \mathrm{pb}$
Expecting Trouble

Surrogacy, Fetal Abuse, and New Reproductive Technologies edited by Patricia Boling

214 pages $\bullet \$ 55.00 \mathrm{hc} \bullet \$ 18.95 \mathrm{pb}$

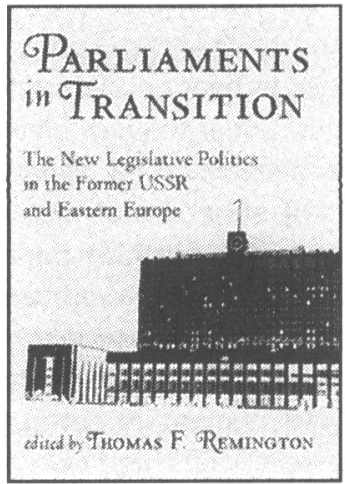

Parliaments in Transition

The New Legislative Politics in the Former USSR and Eastern Europe edited by Thomas F. Remington 246 pages $\$ 54.95 \mathrm{hc} \bullet \$ 19.95 \mathrm{pb}$

\section{Transforming American Politics}

Lawrence C. Dodd, series editor

\section{Congressional Politics}

The Evolving Legislative System, Second Edition

Leroy N. Rieselbach 500 pages $\bullet \$ 75.00 \mathrm{hc} \bullet \$ 29.95 \mathrm{pb}$

\section{Campaigns and Elections} American Style edited by James A. Thurber and Candice J. Nelson 256 pages $\bullet \$ 65.00 \mathrm{hc} \bullet \$ 19.95 \mathrm{pb}$

\section{The New American Politics}

Reflections on Political Change and the Clinton Administration edited by Bryan D. Jones 316 pages $\bullet \$ 65.00 \mathrm{hc} \bullet \$ 24.95 \mathrm{pb}$

\section{WestviewPress}
A Division of HarperCollinsPublishers 


\section{CALIFORNIA $\begin{array}{r}\text { Political } \\ \text { science }\end{array}$}

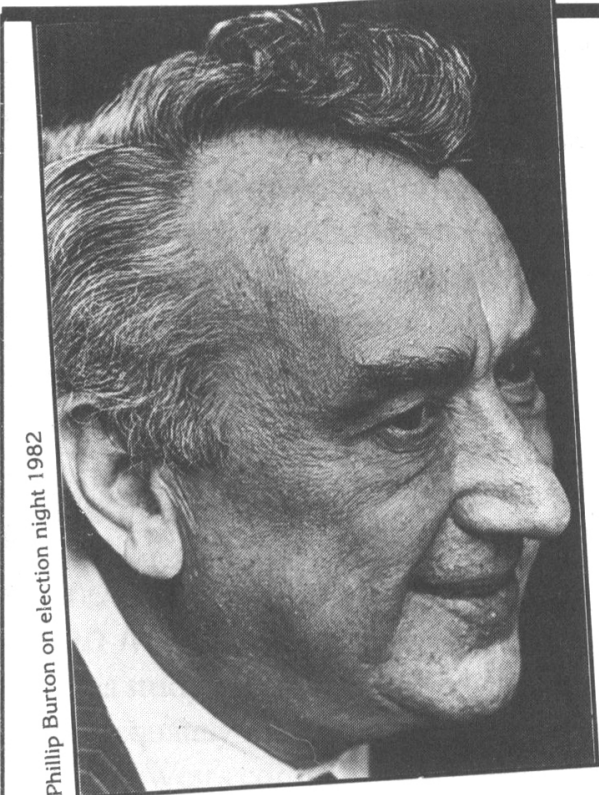

JOHN JACOBS

A Rage for Justice

The Passion and Politics of

Phillip Burton

"There was no more compelling political figure in the America of the 1960s and 1970s than California's Phillip Burton and now John Jacobs has written a book that fits the manbig, boisterous, insightful, and compelling. Jacobs has captured Burton and has captured the fascinating politics of the Bay Area, California, and the House of Representatives, all in one terrific package."

-Norman J. Ornstein,

American Enterprise Institute $\$ 34.95$ cloth, illustrated

\section{S. PAIGE BATY \\ American Monroe}

\section{JAMES DAY}

\section{The Vanishing Vision}

The Inside Story of Public

Television

"The long, unfinished struggle to create-against daunting odds-an alternative television not tethered to market forces is Day's theme in this sweeping chronicle. This story-one of achievement eroded by internal dissention but, more significantly, by political log-rolling and chicaneryneeds to be told, and Day does so with panache." -Erik Barnouw, author of Tube of Plenty $\$ 29.95$ cloth, illustrated

\section{ANDREW G. WALDER, Editor} The Waning of the Communist State Economic Origins of Political Decline in China and Hungary

This collection of essays offers a compelling explanation for the decline of communism in the two countries that went the furthest with economic reforms-China and Hungary.

Studies on China, $\$ 40.00$ cloth
The Making of a Body Politic

"Baty not only offers a provocative reading of the iconographic, biographic, cartographic and hagiographic modes in which 'Marilyn' has been written by others, but also gives us a novel theorization of how popular culture translates, transforms, and embodies the political sphere." -Vivian Sobchack, author of The Address of the Eye $\$ 40.00$ cloth, $\$ 15.00$ paper, illustrated

\section{PETER DUUS \\ The Abacus and the Sword}

The Japanese Penetration of Korea, 1895-1910

Duus brings a new perspective to Meiji expansionism in this pathbreaking study of Japan's acquisition of Korea, the largest of its colonial possessions.

"In the field of Japanese imperialism, [this] will set a standard for careful and comprehensive analysis."

-Mark R. Peattie, author of Nan'yo Twentieth-Century Japan, A Philip E. Lilienthal Book, \$45.00 cloth, illustrated
MERON BENVENISTI

\section{Intimate Enemies}

Jews and Arabs in a

Shared Land

Foreword by Thomas L. Friedman

"Honest to a fault, possessed of no illusions, with no ax to grind,

Benvenisti has insisted that Israeli and Palestinian should acknowledge the facts of their world. Controversial .. he has gone his own way." -Fouad Ajami, author of The Arab Predicament

$\$ 24.95$ cloth

\section{SUSAN WALTZ}

\section{Human Rights and Reform}

\section{Changing the Face of} North African Politics

This study, the first systematic comparative analysis of North African politics in more than a decade, explores the ability of society, including Islamist forces, to challenge the powers of states. $\$ 45.00$ cloth, $\$ 16.00$ paper

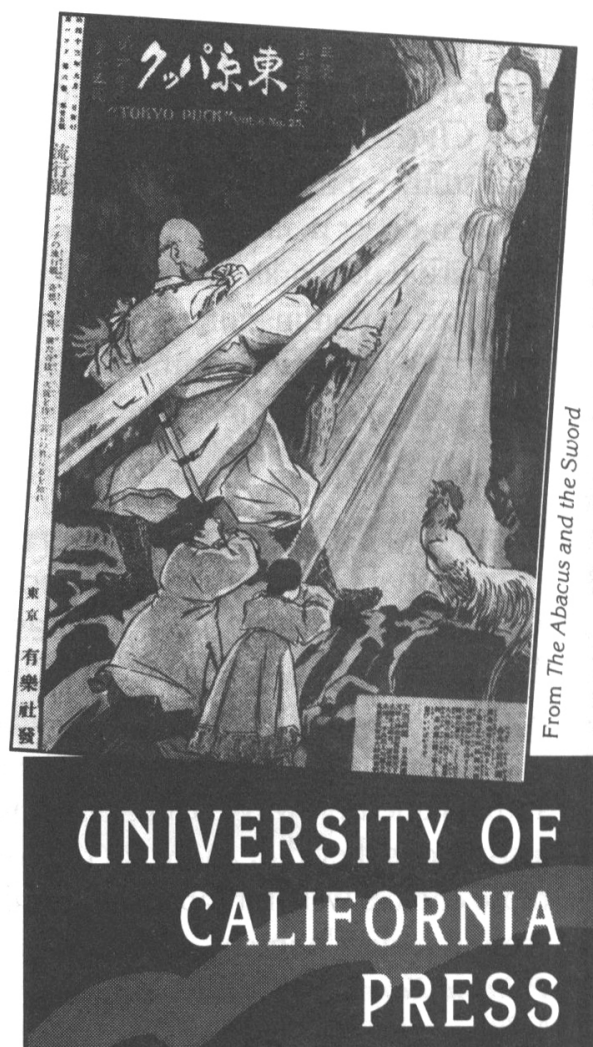




\section{THE BEST IN POLTICS}

\section{The Amateur Strategist}

Intuitive Deterrence Theories and the Politics of the Nuclear Arms Race

\section{James DeNardo}

Demonstrating that novices can reason like professional strategists, this study of amateur nuclear strategic reasoning reveals surprising patterns of thinking that challenge the intellectual foundations of modern deterrence theory, public opinion studies and game theory.

Cambridge Studies in Political Psychology

and Public Opinion

48121-X Hardback \$59.95

48446-4 Paperback \$19.95

\section{With Malice Toward Some}

How People Make Civil Liberties Judgments George E. Marcus, John L. Sullivan, Elizabeth Theiss-Morse, and Sandra L. Wood How do citizens faced with a complex variety of choices decide whether or not to tolerate extremist groups? Relying on several survey-experiments, this text compares the impact on decision making of contemporary information, long-standing predispositions, and enduring values and beliefs.

Cambridge Studies in Political Psycbology

and Public Opinion

43396-7 Hardback \$59.95

43997-3 Paperback $\$ 19.95$

\section{Serious Money}

Fundraising and Contributing in Presidential Nomination Campaigns

Clifford W. Brown, Jr., Lynda W. Powell, and Clyde Wilcox

This study explores the fundamental differences between direct mail solicitation and personalsolicitation networks, and the influence of candidate resources in nomination campaigns. It is based on surveys and interviews with contributors and campaign fundraising professionals.

44058-0 Hardback $\$ 54.95$

49780-9 Paperback \$19.95

\section{The Politics of Oligarchy}

\section{Institutional Choice in Imperial Japan}

\section{J. Mark Ramseyer and Frances $M$. Rosenbluth}

This book examines a key question of modern Japanese politics: why the Meiji oligarchs were unable to design institutions capable of protecting their power. The authors question why the oligarchs chose the political institutions they did, and what the consequences of those choices were for Japan's political competition, economic development, and diplomatic relations. Political Economy of Institutions and Decisions 47397-7 Hardback \$54.95

\section{Modern Polfitical Economy}

Old Topics, New Directions

Jeffrey S. Banks and

Eric A. Hanushek, Editors

"This collection of new papers presents and surveys some aspects of this new field [of political economy] and reminds us of how wide-ranging its achievements are. It should be of value not only to economists but to political scientists as well."

- Mancur Olson,

University of Maryland at College Park

Contributors: Jeffrey S. Banks, Eric A. Hanushek,

David P. Baron, William Riker, David L. Weimer,

Raymond Riezman, John Douglas Wilson, Alberto Alesina, Edward M. Gramlich, John Ferejohn, Randall L. Calvert, Pablo T. Spiller

Political Economy of Institutions and Decisions

47233-4 Hardback \$54.95

47810-3 Paperback $\$ 17.95$

\section{Sustainable Democracy Adam Przeworski}

The joint report of twenty-one social scientists who collaborated over two years under the name of the Group of East-South Systems Transformations (ESST) identifies the principal political and economic choices confronting new democracies in Southern and Eastern Europe and South America.

Contributors: Pranab Bardhan, Luiz Carlos Bresser Pereira, Laszlo Bruszt, Jang Jip Choi, Ellen Turkish Comisso,

Zhiyuan Cui, Torcuato di Tella, Elemer Hankiss, Lena Kolarska-Bobinska, David Laitin, José Maria Maravall, Andranik Migranyan, Guillermo O'Donnell, Ergun Ozbudun, John Roemer, Philippe C. Schmitter, Barbara Stallings, Alfred Stepan, Francisco Weffort, Jerzy J. Wiatr 48261-5 Hardback \$44.95

48375-1 Paperback \$14.95

\section{Hannah Arendt and Leo Strauss}

German Emigrés and American Political Thought After World War II

Peter Graf Kielmansegg, Horst Mewes, and Elisabeth Glaser-Schmidt, Editors

This book explores the influence of Hannah Arendr's and Leo Strauss' background in pre-WWII Germany on their perception of American democracy. The contributors analyze how their émigré experience both influenced their American work and also impacted on the formation of the discipline of political science in postwar Germany.

Contributors: Helmut Dubiel, Timothy Fuller, Jürgen Gebhardt, George Kateb, Horst Mewes, Robert B. Pippin, Alfons Söllner, Ernst Vollrath

Publications of the German Historical Institute,

Washington, D.C.

47082-X Hardback \$49.95 


\section{THE BEST IN POLITICS}

Social Movements, Political Violence, and the State

A Comparative Analysis of Italy and Germany Donatella della Porta

This book presents empirical research on the nature and structure of political violence. While most studies of social movements focus on single-nation studies, della Porta uses a comparative research design to analyze movements in two countries - Italy and Germany from the 1960 s to the 1990 s.

Cambridge Studies in Comparative Politics

47396-9 Hardback \$59.95

\section{Beyond the Two Party System}

Political Representation, Economic Competitiveness and Australian Politics

lan Marsh

This study suggests that the two party system inadequately meets the current increased demands of the West's competitive governments and culturally and ethically diverse societies. It accordingly outlines the ways in which politics might change to achieve genuine participatory democracy.

Reshaping Australian Institutions 1

46223-1 Hardback \$64.95

\section{The Collapse of}

\section{a Single Party System}

The Disintegration of the Communist Party

of the Soviet Union

\section{Graeme Gill}

Following the debates in the Communist party over the implications of Gorbachev's reforms, this in-depth analysis of its disintegration (1985-1991) reveals the institutional dynamics and pressures that ultimately led to the collapse of the most powerful single-party state in history.

Cambridge Russian, Soviet and Post-Soviet Studies 94

46537-0 Hardback \$59.95

46943-0 Paperback $\$ 18.95$

\section{Karl Marx's Theory of Ideas} John Torrance

Karl Marx's writings contain, besides economic analysis and the political theory of revolutionary communism, an influential sociology of ideas, explaining how social life shapes and distorts people's ideas and beliefs.

This book presents a fresh critical study of this theory, establishing what Marx did and did not say, and distinguishing the more scientific parts of his thought from those which were over-influenced by his revolutionary aims.

Studies in Marxism and Social Theory

44066-1 Hardback \$59.95

\section{Democracy Against Capitalism}

Renewing Historical Materialism

Ellen Meiksins Wood

This study argues that understanding Marxism and its critique of capitalism is more important than ever because of the collapse of Communism. It redefines historical materialism's basic concepts and theory of history to specifically identify capitalism as a system of social relations and political power.

47096-X Hardback \$59.95

47682-8 Paperback $\$ 18.95$

\section{World Cities \\ in a World-System}

Paul L. Knox and Peter J. Taylor, Editors

The dominating influence of a relatively small number of cities has characterized the shift to an increasingly global economy during the 1970s and 1980s. Eighteen original essays examine the nature, demands and relationships of cities such as New York, Tokyo and London.

Contributors: Paul L. Knox, John Friedmann, Peter J. Taylor, Saskia Sassen, David A. Smith, Michael Timberlake,

Donald Lyons, Scott Salmon, David J. Keeling, David Simon, Ramoón Grosfuegel, Janet Lippman Abu-Lughod, Graham Todd, Anthony D. King, Robert A. Beauregard, Michael Peter Smith, Andrew Kirby, Sallie Marston, Kenneth Seasholes, Roger Keil, Peter M. Ward, Manuel Castells

48165-1 Hardback \$64.95

48470-7 Paperback $\$ 19.95$

Now in paperback...

The Search for Rational Drug Control

Franklin E. Zimring and

Gordon Hawkins

"Zimring and Hawkins offer a devastating critique of the premises and tactics of U.S. antidrug policy... The critical aspects of this book are its strength and are required reading for scholars in this area."

55882-4 Paperback $\$ 16.95$

Available in bookstores or from

\section{CAMBRIDGE UNIVERSITY PRESS}

40 West 20th Street, N.Y., NY 10011-4211

Call toll-free 800-872-7423

MasterCard/VISA accepted.

Prices subject to change.

Web site: http://www.cup.org 


\section{The Southern Strategy \\ Revisited}

Republican Top-Down Advancement in the South

JOSEPH A. AISTRUP

"No other effort so extensively examines the potential linkage between GOP success at the presidential level and Republican performance further down the ballot .... A valuable contribution to the literature on southern politics."

-Charles S. Bullock III

288 pages

cloth $\$ 39.00$

\section{Henry Clay and the}

American System

MAURICE G. BAXTER

"A balanced, objective and highly readable account of one of the most interesting, important and controversial subjects of the early nineteenth century."

-Robert V. Remini

272 pages

cloth $\$ 34.95$

\section{Nativism Reborn?}

The Official English Language

Movement and the American States

RAYMOND TATALOVICH

"Must reading for anyone who wants to understand the politics of language or Latino politics in the United States."

-Kenneth J. Meier

336 pages

cloth $\$ 29.95$

\section{Forthcoming in Paper!}

The Banana Men

American Mercenaries and

Entrepreneurs in Central America,

1880-1930

LESTER D. LANGLEY AND

THOMAS D. SCHOONOVER

"Represents an important contribution to the literature on US intervention in 20th-century Latin America."-Choice 232 pages

cloth $\$ 29.95$

paper \$17.95-available December 1995

\section{Power and Profits}

U.S. Policy in Central America

RONALD W. COX

"Should be a catalyst for further studies of how and by whom U.S. foreign policy is made, and Cox should be commended for being a pathfinder in this area."-Choice 200 pages

cloth $\$ 29.00$

\section{The Great Powers and Global Struggle, 1490-1990}

KAREN A. RASLER AND

WILLIAM R. THOMPSON

Explores the rise and fall of world powers over the past five hundred years.

296 pages

cloth $\$ 35.00$

\section{Peace and Disarmament}

Naval Rivalry and Arms Control, 1922-1933

RICHARD W. FANNING

"A very important study of a major effort to achieve restriction in arms." - Choice 236 pages cloth $\$ 35.00$

TO ORDER CALL 1-800-839-6855

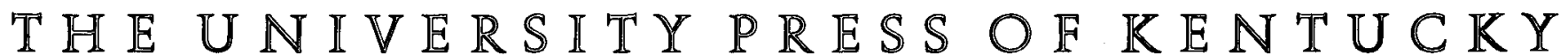
$663 \mathrm{South}$ Limestone Street. Lexington, Kentucky 40508

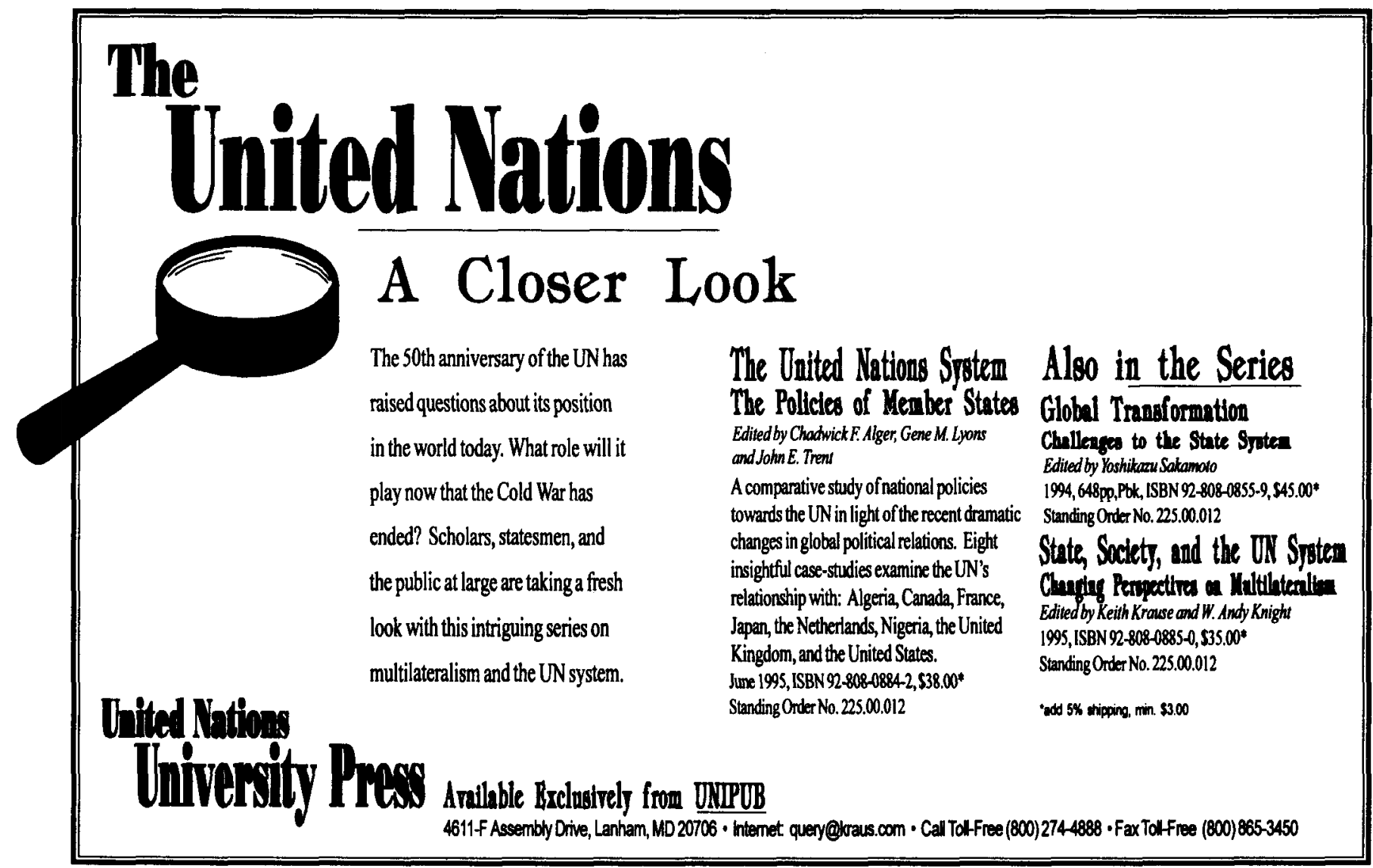




\section{New and Forthcoming from Duke}

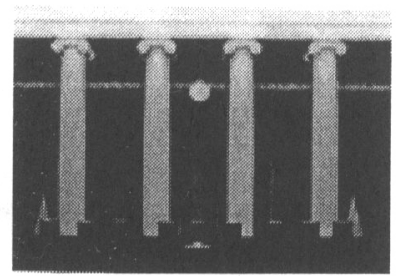

A YEAR IN THE LIFE OF THE SUPREME COURT

Rodney A. Smolla, editor 304 pages, paper $\$ 14.95$, library cloth edition $\$ 39.95$

Constitutional Conflicts

\section{GOVERNING THE}

\section{NEW EUROPE}

Jack Hayward and Edward C. Page 424 pages, paper $\$ 19.95$,

library cloth edition $\$ 49.95$

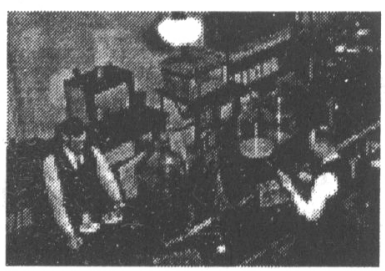

POLITICS ON THE

ENDLESS FRONTIER

Postwar Research Policy in the United States

Daniel Lee Kleinman

240 pages, 21 tables, paper $\$ 16.95$, library cloth edition $\$ 39.95$

\section{THEORIES AND}

NARRATIVES

Reflections on the Philosophy

of History

Alex Callinicos

264 pages, paper $\$ 16.95$, library cloth edition $\$ 45.00$
THE RHETORIC OF

CHURCH AND STATE

A Critical Analysis of Religion

Clause Jurisprudence

Frederick Mark Gedicks

184 pages, paper $\$ 18.95$,

library cloth edition $\$ 49.95$

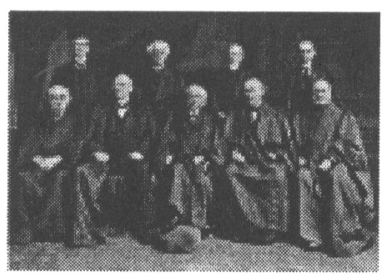

Now in Paperback

THE CONSTITUTION

\section{BESIEGED}

The Rise and Demise of Lochner Era

Police Powers Jurisprudence

Howard Gillman

328 pages, paper $\$ 15.95$

\section{MANAGING LEGAL UNCERTAINTY}

Elite Lawyers in the New Deal Ronen Shamir

304 pages, paper $\$ 18.95$, library cloth edition $\$ 45.00$

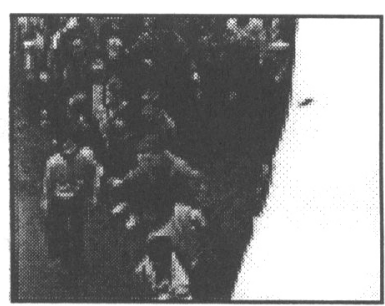

\section{THE REINCARNATION} OF RUSSIA

Struggling with the Legacy of

Communism, 1990-1994

John Löwenhardt

256 pages, paper $\$ 15.95$,

library cloth edition $\$ 42.50$
IMPERIAL BORDERLAND

Bobrikov and the Attempted

Russification of Finland,

1898-1904

Tuomo Polvinen

Translated by Steven Huxley

272 pages, 8 b\&w photographs, cloth $\$ 29.95$

\section{ENVIRONMENTAL} POLITICS AND POLICY

Theories and Evidence

Second Edition

James P. Lester, editor

384 pages, 8 illustrations,

paper $\$ 22.95$,

library cloth edition $\$ 59.95$

\section{ANIMALS AND WOMEN}

Feminist Theoretical Explorations

Carol J. Adams and Josephine

Donovan, editors

360 pages, paper $\$ 16.95$,

library cloth edition $\$ 49.95$

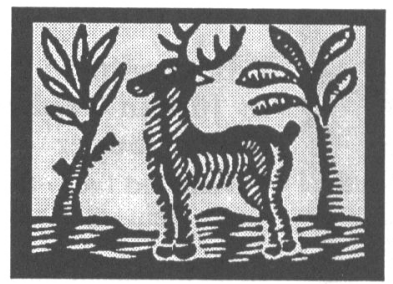

BEYOND PREJUDICE

The Moral Significance of

Human and Nonhuman Animals

Evelyn B. Pluhar

With a Foreword by

Bernard E. Rollin

416 pages, paper $\$ 19.95$,

library cloth edition $\$ 49.95$

DUKE UNIVERSITY PRESS

Box 90660

Durham, NC 27708-0660 


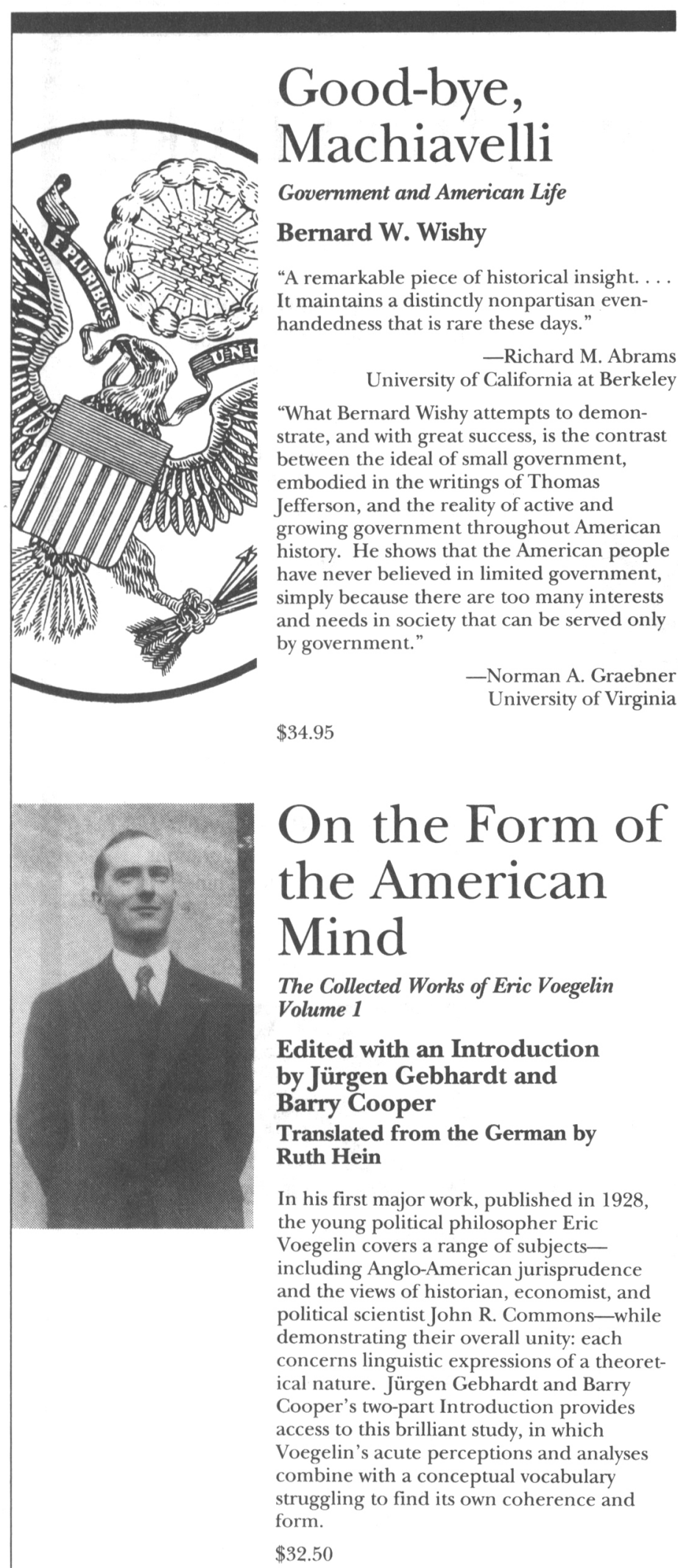

Louisiana State University Press

P. O. Box 25053 - Baton Rouge, LA $70894-5053$

Credit-card orders: $800-861-3477$

\section{Past and Future of U.S. Intelligence}

\section{DIRTY TRICKS OR TRUMP CARDS U.S. Counterintelligence \& Covert Action RoY GoDson}

\section{ISBN 1-57488-034-9 \$24.95 Hardcover 326 pages}

Are covert operations "dirty tricks" or trump cards that skillfully played, provide significant advantages in world politics? Roy Godson, one of today's most influential scholars on intelligence, marshals historical, comparative and contemporary experience to answer these questions. This balanced and impressive study fills a major void in the literature.

As the U.S. debates the future of its intelligence capability, this provocative and interesting book should be permitted to have a significant impact.

Richard Helms, former director of Central Intelligence ... an outstanding analysis. This timely book is an important contribution to an understanding of intelligence requirements in a still dangerous world.

Robert L. Pflatzgraff, Jr. ,

Fletcher School of Law and Diplomacy

\section{U.S. INTELLIGENCE AT THE CROSSROAdS Agendas for Reform ROY GODSON, ERNEST MAY \& GARY SCHMITT, Eds.}

\section{ISBN 1-57488-036-5 \$25.95 Hardcover 256 pages}

Divergent perspectives on topics ranging from the very purposes of intelligence, to pressing policy concerns about weapons proliferation, economic espionage, and threats posed by nonstate actors such as criminal and terrorist organizations. Contributors include senior officials from CIA, FBI, State and Defense, as well as academic specialists such as Joseph Nye and James $Q$. Wilson.

Virtually indispensable for any outsider who wants to be reasonably up-to-date on what insiders have in mind (besides budgets and organization charts) when they talk about U.S. intelligence reform today.

H. Bradford Westerfield, Yale University

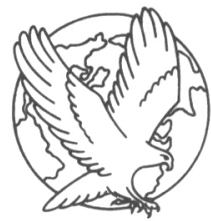

Published by BRASSEY'S, Inc.
To order

Call Toll Free 1-800-775-2518 or Fax: (703) 689-0660 Order Fulfillment:

P.O. Box 960, Herndon, VA 22070 Available at Bookstores 


\section{BASIC political science}

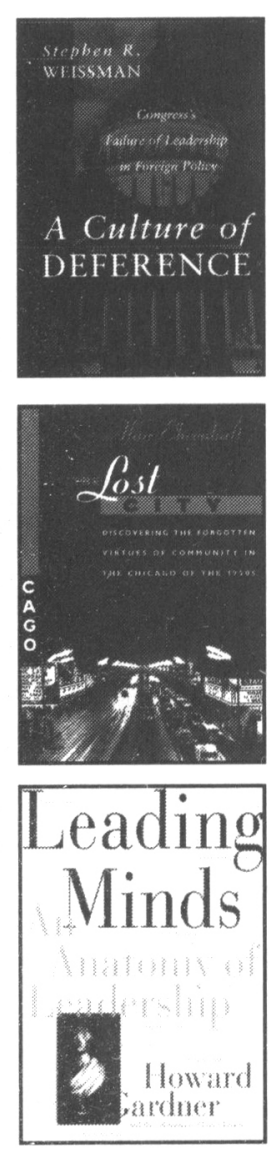

A CULTURE OF DEFERENCE

Congress's Failure of Leadership in Foreign Policy STEPHEN R. WEISSMAN

An inside look at how congressional deference to the presidency and State Department has lead to such recent policy failures as Somalia, Bosnia, and Iraq.

$\$ 26.00$

\section{THE LOST CITY}

Discovering the Forgotten Virtues of Community in the Chicago of the 1950s ALAN EHRENHALT

"If you have time to read only one book this year, make it The Lost City." -Amitai Etzioni, author of The Spirit of Community $\$ 23.00$

\section{LEADING MINDS}

An Anatomy of Leadership

HOWARD GARDNER

With the collaboration of EMMA LASKIN

"Once again, Gardner brings his brilliant intuition and analytic skills to the study of human excellence."-Edward O. Wilson, Harvard University

$\$ 27.50$

\section{$\frac{.5}{6}$ \\ n 0 w \\ i n \\ p a p \\ THE NEW REPUBLIC READER}

Toward the Resolution of Intractable Policy Controversies

DONALD A. SCHÖN \&

MARTIN REIN

This innovative approach shows how "reframing" the issues can lead to success where simply appealing to facts often fails. $\$ 15.00$

\section{THE LIVING AND THE DEAD}

The Rise and Fall of the Cult of

World War II in Russia

NINA TUMARKIN

"A seamless weaving of vigorous scholarship and personal experience."-Boston Globe

$\$ 15.00$ century."-Los Angeles Times
Eighty Years of Opinion and Debate

DOROTHY WICKENDEN, ED.

"A rich repository of writings that spans the turmoils and triumphs of the twentieth

$\$ 16.00$ A NEW REPUBLIC BOOK

\section{NIXON RECONSIDERED}

JOAN HOFF

"What sets this book apart is its exhaustive research and the provocative intellectual framework within which the Nixon

Presidency is assessed."-New York Times Book Review

$\$ 16.00$

\section{POSTETHNIC AMERICA}

Beyond Multiculturalism

DAVID A. HOLLINGER

"A blueprint for moving the debate over multiculturalism from polarized and politicized confrontation to constructive dialogues." - Kirkus $\$ 22.00$

\section{THE WAR AGAINST}

\section{THE POOR}

The Underclass and Antipoverty Policy Herbert J. Gans

"Lays bare America's obsession with the poor. ... [This] may be a painful book to read, but we avoid it at our peril."-Andrew Hacker, author of Two Nations

$\$ 22.00$

\section{THE VISION OF THE ANOINTED}

Self-Congratulation as a Basis for

Social Policy

THOMAS SOWELL

"Sowell's books on race, economics, and markets have constituted a rare repository of insights on some of the most pressing socialscience concerns of our time." - Wall Street Journal

$\$ 25.00$

\section{a c k

\section{NO TURNING BACK \\ Dismantling the Fantasies of Environmental Thinking Wallace Kaufman \\ "Stimulating . . Kaufman discusses new technologies and suggests that private enterprises are not necessarily antigovern- ment and can be beneficial as a resource."-Publishers Weekly $\$ 13.50$}

\section{RACE AND CULTURE}

A World View

THOMAS SOWELL

"Will compel every careful reader . . . to rethink their most confident views on matters of race and culture."-National Review $\$ 14.00$ 


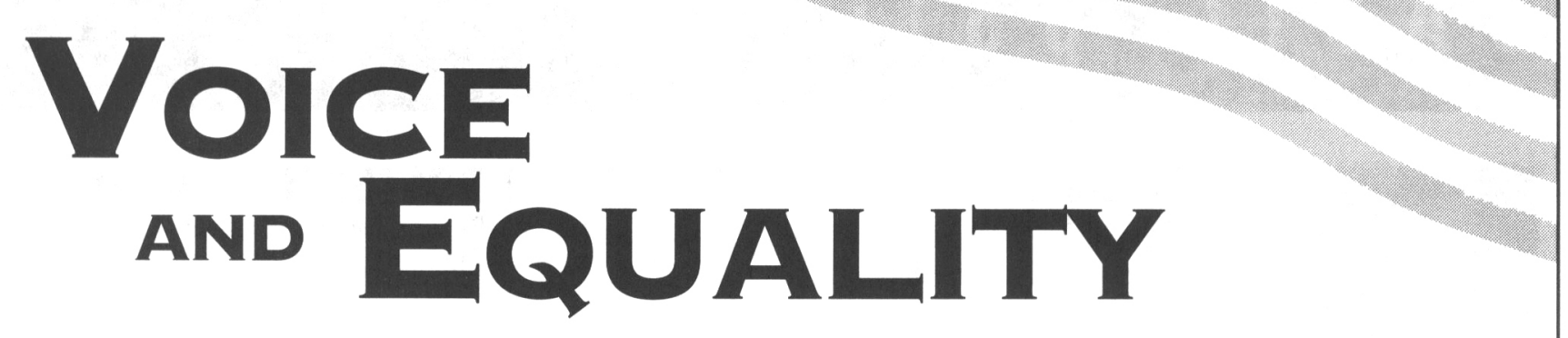

\section{Civic Voluntarism in American Politics}

\section{Sidney Verba, Kay Lehman Schlozman, and Henry E. Brady}

"Meaningful democratic participation requires that the voices of citizens in politics be clear, loud, and equal: clear so that public officials know what citizens want and need, loud so that officials have an incentive to pay attention to what they hear, and equal so that the democratic ideal of

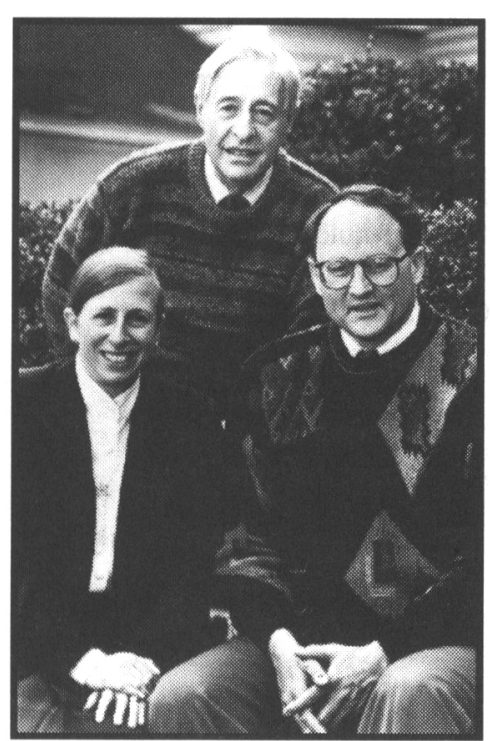

equal responsiveness to the preferences and interests of all is not violated. Our analysis of voluntary activity in American politics suggests that the public's voice is often loud, sometimes clear, but rarely equal."

\section{-From the book}

This book confirms Alexis de Tocqueville's idea, dating back a century and a half, that American democracy is rooted in civil society. Citizens' involvement in family, school, work, voluntary associations, and religion has a significant impact on their participation as voters, campaigners, donors, community activists, and protesters. The authors have created an original survey of 15,000 individuals, which includes 2,500 personal interviews, that focuses on the central issues of involvement: how people come to be active, their motivations, their resources, and their networks. We see fascinating differences along cultural lines, observe family activism moving from generation to generation, and look into the special role of issues that elicit involvement, including abortion rights and social welfare.

\section{Available now in cloth and paperback}

46 line illus., 70 tables 512 pp.

ISBN 0-674-94292-2 \$39.95 cloth

ISBN 0-674-94293-0 \$17.95 paper
"A seminal work in the field of American politics. It is theoretically rich, methodologically sound, and brilliantly executed... As a work of survey research this book is a model of how data should be weighed, displayed, and interpreted."

-Jeffrey M. Berry, Tufts University 


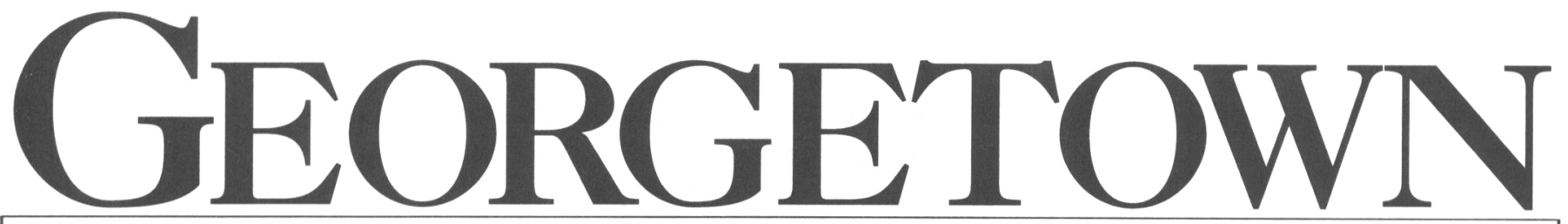

\section{New and Recent Books on Public Policy}
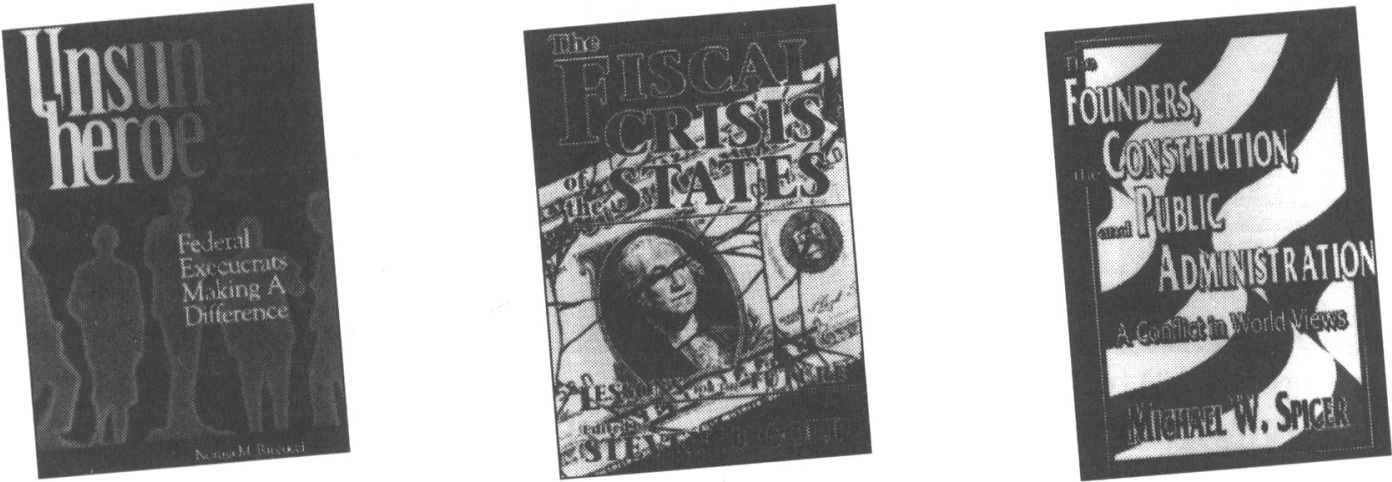

\section{Unsung Heroes}

\section{Federal Execucrats Making a Difference}

NORMA M. RicCUCCI

"An extraordinarily important, inherently interesting, and readable book ... she provides us with a valuable framework for systematically understanding how top civil servants achieve policy objectives"-David Rosenbloom, Distinguished Professor of Public Affairs, The American University. 272 pp. Cloth: ISBN 0-87840-592-5, \$45.00 Paper: ISBN 0-87840-595-x, \$17.95

\section{The Fiscal Crisis of the States}

Lessons for the Future

Steven D. Gold, Editor

"A much needed examination of the fiscal condition of the fifty states in the 1990s.... Necessary reading for those who are concerned about the next crisis in state finances: The shifting of federal responsibilities down the system"Thad Beyle, professor of political science, University of North Carolina at Chapel Hill

406 pp. Cloth: ISBN 0-87840-574-7, \$42.50

Paper: ISBN 0-87840-575-5, \$19.95

\section{The Founders, The Constitution,} and Public Administration

\section{A Conflict in World Views}

Michael W. Spicer

"An intriguing application of the anti-rationalist perspective to administration theory... a particularly good epitaph to the New Deal, Executive-Centered tradition"-James

A. Stever, professor of political science, University of Cincinnati

128 pp. Cloth: ISBN 0-87840-581-x, \$27.50

Paper: ISBN 0-87840-582-8, \$13.95

\section{A New Vocabulary for} Governing in the 1990s

A Lexicon for Governors' Policy Advisors

Tom Bonnett

This compendium of terms used in public and private management is a practical tool for people working in government, nonprofit organizations, academe, and policy study institutions.

Council for Governors' Policy Advisors

60 pp. Paper: ISBN 0-934842-14-0, \$8.95

\section{The Environment}

\section{Goes to Market}

The Implementation of Economic Incentives for Pollution Control

National Academy of Public Administration

Focusing on the practical aspects of using economic incentives to achieve environmental goals, this book examines the design and implementation of market based programs by analyzing four case studies at varying levels of government, and identifying the critical issues for creating successful programs in the future.

232 pp. Paper: ISBN 0-9646874-0-2, \$20.00

\section{Georgetown University Press}




\section{NEW FROM THIE FREE PRESS}

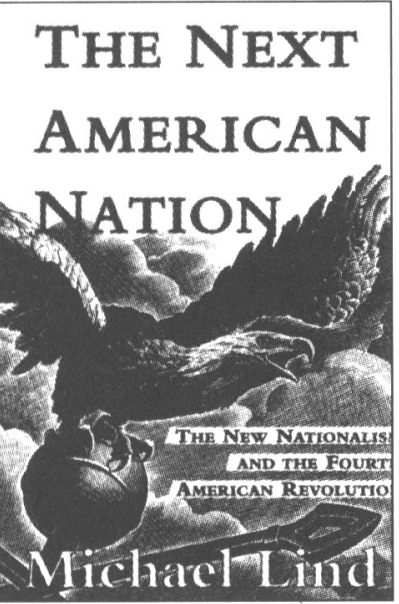

THE NEXT

AMIERICAN NATION

The New Nationalism and the Fourth American Revolution

\section{Michael Lind}

6 Lind's brilliantly disturbing book shows that America is not a democracy of citizens but an oligarchy of professionals, a new class system based on credentials, and a new pseudo-aristocracy privileged to the luxury of affirmative action on the basis of hereditary right. Lind offers thoughtful radical solutions to these problems, and for good conservative reasons. 99 - John Patrick Diggins,

City University of New York

1995 ISBN: 0-02-919103-3 \$25.00

\section{ONE BY ONE FROM THE INSIDE OUT}

Essays and Reviews on Race and Responsibility In America

\section{Glenn C. Loury}

6 A valuable book. Loury writes with clarity and power. He is fearlessly blunt. He can be especially biting when criticizing black intellectuals on his left. Loury recognizes that the way to resolve America's race problem is to find a solution for its underclass problem.99

-The New York Times Book Review

1995 ISBN: 0-02-91944I-5 \$25.00

\section{CHURCHILL}

The Unruly Giant

\section{Norman Rose}

${ }^{6} 6$ This balance and breadth, this combination of sympathy and detachment, and this wideranging historical vision, mark out this book as the best one-volume life yet written.99

-David Cannadine,

Columbia University

1995 ISBN: 0-02-874009-2 \$25.00

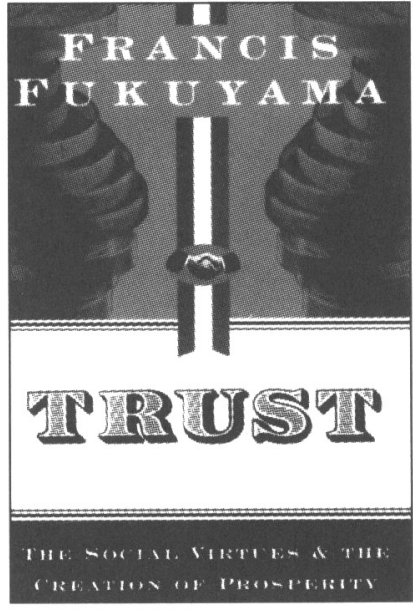

TRUST

The Social Virtues and the Creation of Prosperity

\section{Francis Fukuyama}

$66 \mathrm{By}$ focusing on the consequences of trust (and its absence) Fukuyama has brought new precision to our comprehension of social capital. In the wake of this book, it will no longer be possible to analyze economic growth without attending to its cultural preconditions. Essential for anyone who wishes to understand the real sources of the wealth of nations. 99

-William A. Galston, University of Maryland 1995 ISBN: 0-02-910976-0 \$25.00

\section{JOHN WAYNE: AMERICAN}

\section{Randy Roberts and James S. Olson}

66Roberts and Olson bring us a fascinating in-depth study of a man who continues to exert his inescapable influence on American culture two decades after his death. John Wayne: American is a look not only at an unforgettable actor, but at ourselves. 99 -Dan Rather

1995 ISBN: 0-02-923837-4 $\$ 28.00$

\section{OVER LORD}

General Pete Quesada and the Triumph of Tactical Air Power in World War II

\section{Thomas Hughes}

66Pete Quesada was one of the finest airmen of World War II, an unsung hero who was critical to the success of the Allies. This excellent biography finally gives him the credit he deserves. 99

-Stephen E. Ambrose, author of D-Day June 6, 1944: The Climactic Battle of World War II

1995 ISBN: 0-02-915351-4 \$28.00

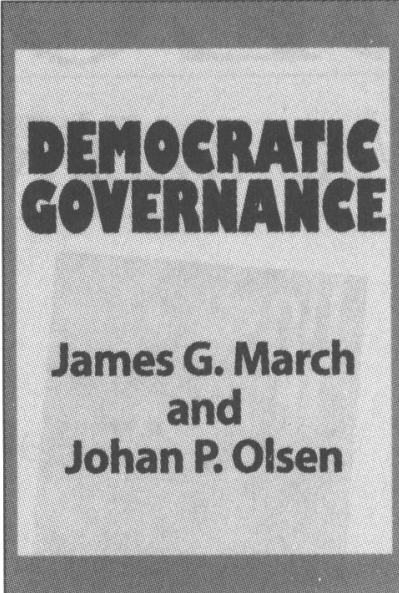

\section{DEMOCRATIC GOVERNANCE}

James G. March and Johan P. Olsen

In this thought-provoking new work, March and Olsen construct a brilliant foundation for thinking about the broad theoretical concerns of democratic governance. Using this framework to challenge key aspects of standard contemporary thinking, March and Olsen draw on social science to examine how political institutions create and sustain democratic solidarity, identities, capabilities, accounts, and adaptiveness; how they can maintain and elaborate democratic values and beliefs - and how governance might be made honorable, just, and effective. Their comprehensive framework for discussion and debate will be read in management, political science, education, psychology and sociology into the 21 st century. 1995 ISBN: $0-02-874054-8 \quad \$ 30.00$

\section{THE LUCK BUSINESS}

The Devastating Consequences of America's Gambling Explosion

\section{Robert Goodman}

${ }^{66}$ To any politician or community that is considering gambling as a way to solve their economic woes: Read this book! Goodman probes the troubling question of what it portends when government pushes a simple solution-one based on luck instead of hard work - to the complex problem of revitalizing our economy. 99

- Scott Harshbarger,

Attorney General of Massachusetts

A Mortin Kessler Book

1995 ISBN: 0-02-912483-2 \$23.00

For credit card orders, call toll-free 1-800-323-7445. 


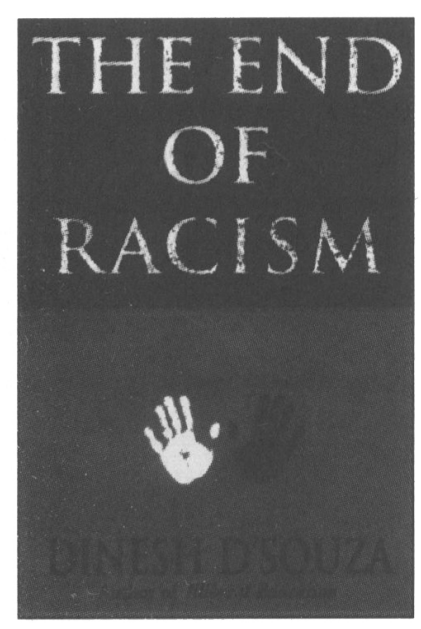

\section{THE END OF RACISM}

\section{Dinesh D'Souza}

66 D'Souza clears away a mountain of rubbish, separates real from spurious issues, and appeals to good sense as well as common decency. No one could possibly agree with all his analyses and opinions, but everyone would profit from a careful reading of, and engagement with, this impressive and badly-needed book. 99 - Eugene Genovese, author of Roll, Jordan, Roll

1995 ISBN: 0-02-908102-5 \$30.00

\section{BEYOND BLAME}

How We Can Succeed by Breaking the Dependency Barrier

\section{Armstrong Williams}

66Williams gives us a 100-page sermon on the value of family, hard work, perseverance and religious salvation in the form of open letters to 'Brad,' a young man whom social workers would describe, at best, as 'at risk.' It is a heartwarming little inspirational tract.99

-New York Newsday

I995 ISBN: 0-02-935365-3 \$18.00

\section{THE END OF THE NATION STATE} The Rise of Regional Economies

\section{Kenichi Ohmae}

660 hmae has stamped his brand on the idea that the information age will have a big impact not only on business but on the shape of international politics. If the cold war is over and money flows around the globe beyond the reach of governments, who, indeed, needs the nation-state? A bold statement of a provocative thesis. 99 -Robert L. Bartley, Editor,

The Wall Street Journal

I995 ISBN: 0-02-923341-0 $\$ 25.00$

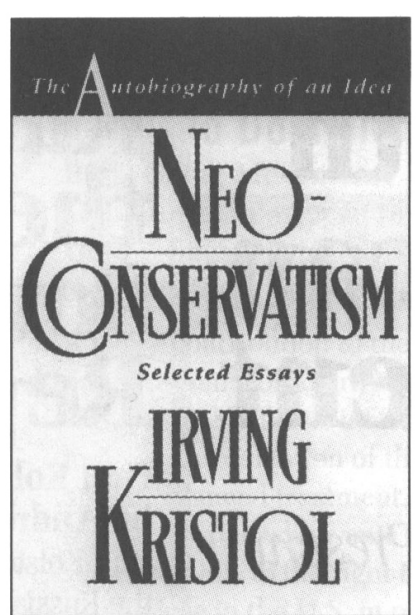

NEOCONSERVATISM

The Autobiography of an Idea

\section{Irving Kristol}

6-Irving Kristol is one of America's most impressive - and most important-social critics and intellectuals. To the unconvinced,

I would simply say: read this superb collection. It will provide you with all the evidence you need.99

-William J. Bennett, author of

The Book of Virtues

I995 ISBN: 0-02-874021-1 $\$ 25.00$

\section{THIE \\ WINNER-TAKE-ALL SOCIETY}

\section{Robert Frank and Philip Cook}

${ }^{66}$ History will look back and see the shift in the American distribution of earnings since the 1970s as the largest that any society has ever had without a revolution or a military defeat and subsequent occupation...Frank and Cook convince me that the spread of 'winner-take-all' markets...is a big part of the explanation. If you read the book, they will also convince you. 99 -Lester Thurow, author of

The Zero-Sum Society

\section{A Mertin Kesster Book}

1995 ISBN: 0-02-874034-3 $\$ 25.00$

\section{LENIN}

\section{A New Biography}

\section{Dmitri Volkogonov}

${ }^{66}$ A stunning barrage of new evidence from archives to which few beside $\mathrm{Mr}$. Volkogonov have had, or are likely to have, access...Lenin will still have his champions, but after this book their task will be much more daunting.99

- The New York Times Book Review 1994 0-02-933435-7 $\$ 30.00$

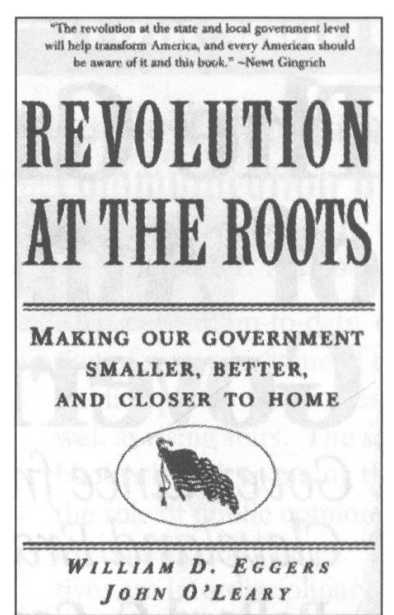

\section{REVOLUTION AT THE ROOTS}

Making Our Government Smaller, Better, and Closer to Home

William D. Eggers and John O'Leary

66The revolution at the state and local government level will help transform America and every American should be aware of it and of this book.99

- Newt Gingrich

1995 ISBH: 0-02-874027-0 \$25.00

\section{THE AGE OF HIROHITO}

In Search of Modern Japan

\section{Daikichi Irokawa}

66Hirohito was the continuum in Japan's age of extremes. Whether a sabered dictator on a white horse or a nondescript biologist with a Mickey Mouse watch, he embodied the contradictions of modern Japan. Irokawa's 'people's history' provides a lucid introduction to Hirohito's long reign, which-after all these studies in the last half century-remains one of the greatest enigmas of our time.99

-Masao Miyoshi,

University of California, San Diego

1995 ISBN: 0-02-915665-3 $\$ 25.00$

\section{Now in paperback-}

THE LEADER'S COMPANION

Insights on Leadership Through the Ages

J. Thomas Wren

1995 ISBN: $0-02-874091-2 \quad \$ 16.95$

\section{THE ARABISTS}

The Romance of an American Elite

Robert D. Kaplan

1995 ISBN: 0-02-874023-8 $\$ 13.00$ 


\section{The Growth of American Government} Governance from the Cleveland Era to the Present Ballard C. Campbell

"A refreshingly unorthodox narrative. Campbell [explains] in plain language how government grew. His stance is neither liberal nor conservative, but simply well-informed and reasonable."

-Walter Nugent, University of Notre Dame

"The canvas is large, but one comes away from the book with an understanding of what has happened, the factors contributing to these developments, and their consequences. Strongly recommended."

-Samuel McSeveney,

Vanderbilt University

This engaging survey of the

growth of government in America in the last century focuses on the evolution of public policy and its relationship to the constitutional and political structure of government at the federal, state, and local levels.

Interdisciplinary Studies in History 304 pages

\section{paper $\$ 14.95$}

(cloth \$35.00)

At bookstores or from

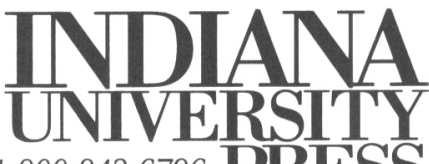

Orders: 1-800-842-6796 PRESS http://uww.indiana.edu/riupress

\section{Russians in the Former Soviet Republics}

Paul Kolstoe, with a contribution by Andrei Edemsky

Paul Kolstoe traces the growth and role of the Russian population in non-Russian areas of the Russian Empire and then in the nonRussian Soviet republics. In the post-Soviet period, special attention is devoted to the situation of Russians in the Baltics, Moldova, Belarus, Ukraine, and the former Central Asian and Caucasian republics. Kolstoe suggests strategies for averting a repetition of the Yugoslav scenario on post-Soviet soil. 348 pages

cloth $\$ 37.50$

\section{Africa}

\section{Third Edition}

Edited by Phyllis M. Martin and Patrick O'Meara

This popular text has been completely revised and brought up to date since the 1986 edition, reflecting changes in African society and politics, and in the scholarship available on this vast and complex continent. 480 pages, 100 b\&w photos, 26 maps paper $\$ 17.95$ (also in cloth $\$ 39.95$ )

\section{When

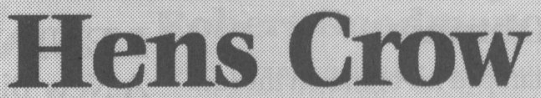

The Woman's Rights Movement in Antebellum America

sylvia D. Hoffert

How leaders of the early woman's rights movement moved beyond the limits of the domestic ideal and "Republican Motherhood" and actively influenced political culture.

Available October

168 pages, 5 b\&w illus.

cloth $\$ 25.00$ 


\section{Current Views on Timely Topics-from Guilford}

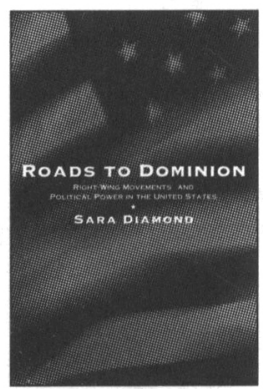

DEMOCRACY

$A N D$

TECHNOLOG Y

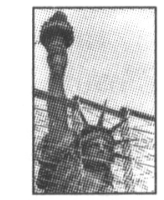

RICHARDE, SCLOVE
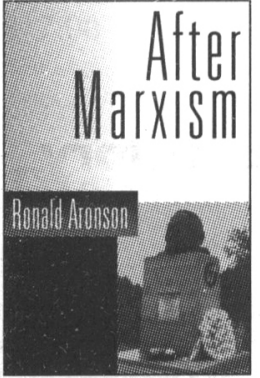

\section{After Marxism}

Ronald Aronson

"An engaging, down-to-earth guide to left-wing theory in the post-Marxist era. After convincingly putting Marx in his place in the museum of noble ideas, [Aronson] introduces a challenging array of contemporary radical thinkers Throughout, he makes it clear that 'after Marx' there are still revolutions to launch and worlds to win."

-Barbara Ehrenreich, author of The Worst Years of Our Lives

321 Pages, 1995, Paper, Cat. \#2416, \$18.95
Roads to Dominion

Right-Wing Movements and Political Power in the

United States

Sara Diamond

"A major contribution to the literature on movements of the right in the U.S....Valuable for its informative and judicious presentation of this history and its balanced treatment.... Should be read by anyone who wants to understand the shift to the right that has taken place in the U.S. in recent decades."

-Barbara Epstein,

University of California, Santa Cruz 445 Pages, 1995, Paper, Cat. \#2864, \$19.95

\section{Democracy and Technology Richard E. Sclove}

"A gold mine of fundamental insights and suggestive provocations concerning the reckless global rush to technological deliverance. At a time when democracy has eroded not only in practice, but also in imagination, Richard Sclove compels us to envision a different world."

-David F. Noble, York University

338 Pages, 1995, Paper, Cat. \#2861, \$18.95

\section{Lewis Mumford and the} Ecological Region

The Politics of Planning

Mark Luccarelli

"Luccarelli brilliantly rediscovers Mumford as the premier urban and environmental thinker for our time." -Frank J. Popper, Rutgers University 233 Pages + Index, 1995, Cat. \#0001, $\$ 26.95$ (tent.)

\section{Marxism in the} Postmodern Age

Confronting the

New World Order

Edited by Antonio Callari, Stephen Cullenberg, and Carole Biewener

"This is without question the best collection of mediations so far on postorthodox Marxian tendencies in contemporary global cultures."

—Sandra Harding, UCLA and University of Delaware 560 Pages, 1995, Paper, Cat. \#2424, \$19.95
Public Opinion and the Communication of Consent

Edited by Theodore L. Glasser and Charles T. Salmon

"An excellent, up-to-date, diverse collection of essays by some of the brightest public opinion scholars established as well as rising stars. The scope of the book is broad, spanning the history of the role of public opinion from ancient to contemporary times. The perspectives are interdisciplinary, with a felicitous blending of philosophical, political, sociological, psychological, and communication perspectives." - Doris Graber, University of Illinois at Chicago

476 Pages, 1995, Paper, Cat. \#2499, \$24.95

\section{Green Production}

Toward an Environmental

Rationality

Enrique Leff

"This book stands at the center of current debates over society and nature, and prompts us to think in entirely new and different terms about sustainable development." -Michael Watts,

University of California, Berkeley 168 Pages, 1995, Paper, Cat. \#2410, \$16.95

\section{Law, Space, and the Geographies of Power}

Nicholas K. Blomley

"A landmark achievement in critical theory and legal theory, a book which provides a way forward for scholars interested in challenging the comfortable presuppositions of the law as we have found it in different localities."

- Gordon L. Clark, Monash University

259 Pages, 1994, Cat. \#2496, \$27.95

\section{G U ILF OR D PUBLICATIONS}

Dept. 6Y, 72 Spring Street, New York, NY 10012 (C) CALL TOLL-FREE 1-800-365-7006 Fax: 212-966-6708, E-mail: info@guilford.com 

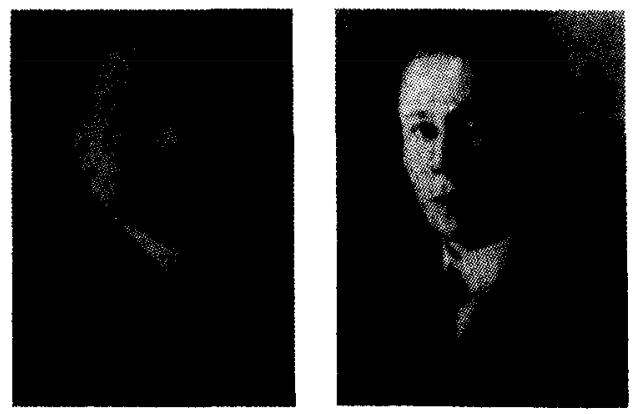

\section{Carl Schmitt and Leo Strauss}

The Hidden Dialogue

Heinrich Meier

Translated by Harvey Lomax

"A gem of a book. Meier's analysis is important, timely, and extremely thoughtful. ... He reconstitutes the nature of the dialogue between Schmitt and Strauss with amazing delicacy and accuracy. The result is a model of careful scholarship, penetrating insight, and historical reconstitution, exploring the relationship between politics and philosophy with precision and depth."

-Roger D. Masters, Dartmouth College

Cloth $\$ 18.95120$ pages

\section{Armageddon in Waco}

Critical Perspectives on the Branch Davidian Conflict Edited by Stuart A. Wright

In this, the most detailed, wide-ranging analysis of events surrounding Waco, leading scholars in sociology, history, law, and religion explore all facets of the confrontation in an attempt to understand one of the most confusing government actions in American history.

•Papor $\$ 15.95344$ pagos

\section{The New Ecological Order}

\section{Luc Ferry}

Translated by Carol Volk

"Environmental activists are demanding a new ecological mindset, one in which nature writ large has the same rights as humans. At the far end of this movement are the deep ecologists, who question whether humans will ever be able to live in harmony with nature. Ferry finds them appalling: antihuman, with tendencies toward authoritarianism, dogmatism, and a strong anticulture streak. ... A closely argued, well-documented, sensitive critique."-Kirkus Reviews

"Paper \$14.95 192 pages

\section{The Myth of Democratic Failure}

Why Political Institutions Are Efficient

\section{Donald A. Wittman}

"Wittman has undertaken the heroic task of using economics to show that economists are wrong to believe, as most of them do, that government is less efficient than markets. This book will make a splash and incite fruitful controversy."-Richard A. Posner Cloth $\$ 29.85200$ pages

Amorican Poltics and Poltical Economy series
Now in Paper

\section{Acts of Hope}

Creating Authority in Literature, Law, and Politics James Boyd White

"James Boyd White is among the wisest and most illuminating of our legal commentators. Acts of Hope furthers his penetrating explorations into the creation of meaning in law:"-Robert C. Post, University of California, Berkeley

Paper $\$ 15.95368$ pages

\section{Numbered Voices}

How Opinion Polling Has Shaped American Politics Susan Herbst

"An original and thought-provoking analysis of why we have polls, what they accomplish, and how they affect the current political scene. Herbst's scholarship is impeccable."-Doris A. Graber, Political Science Quarterly

Paper $\$ 14.95235$ pages

American Polltics and Political Economy serles

\section{American Economic Policy} in the 1980s

\section{Edited and with an Introductory Essay by}

Martin Feldstein

Martin Feldstein, former chairman of the Council of Economic Advisers during the Reagan administration, and other leading economists and policymakers provide compelling analysis of the policies which helped shape America's economy in the 1980s. An NBEA Conforence Report

\section{Economics and World History Myths and Paradoxes \\ Paul Bairoch}

Bairoch argues that several commonly held beliefs are based on insufficient knowledge and misguided interpretations of the economic history of the United States, Europe, and the Third World. "A challenging and readable introduction to some major controversial themes in modern international economic history."

- Peter J. Cain, International History Review

Paper $\$ 13.95200$ pages

\section{Chicago \\ The University of Chicago Press}

5801 South Ellis Avenue, Chicago, Illinois 60637 


\section{$\mathrm{P}$ a p e r b o u n d s f r o m Y a l e}

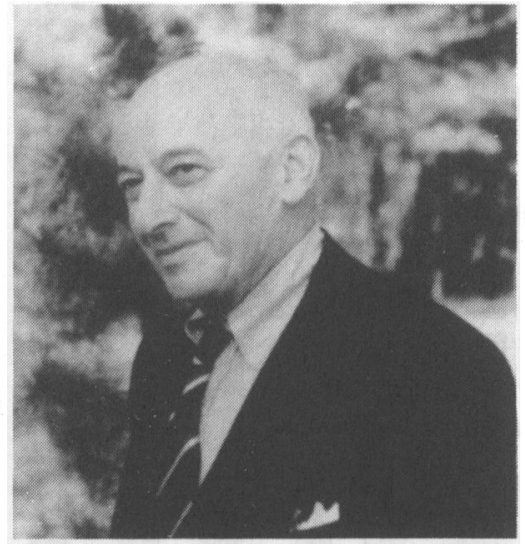

Toward

\section{Managed Peace}

The National Security Interests of the United States, 1759 to the Present

Eugene V. Rostow

"A brilliant review of the evolution of U.S. foreign policy with particular emphasis upon the rule of law. It is important reading for all those interested in U.S. policy formulation for the future."

- The Honorable Paul H. Nitze $\$ 17.00$

Published by Yale University Press and National Deferise University Press

\section{The Workers' Party and \\ Democratization in Brazil}

Margaret E. Keck

"A wonderful book. The arguments are convincing, the prose refreshingly clear....[Keck's] study will likely be foundational and indelible for subsequent scholarship on the Workers' Party."

-Ben Ross Schneider, American

Political Science Review $\$ 18.00$

Winner of the 1993 New England Council on Latin American Studies Book Award

\section{Power Without Responsibility}

How Congress Abuses the People Through Delegation

David Schoenbrod

"An important book about revitalizing democracy. Federal bureaus are often unaccountable [and], delegation of rule-making is one of the reasons. Schoenbrod shows us how to make elected representatives and the federal bureaucracy once again accountable to the people."

-Senator Bill Bradley $\$ 14.00$

\section{The Politics of Pregnancy}

Adolescent Sexuality and Public Policy

Edited by Annette Lawson and Deborah L. Rhode

"[This] book tells us something frightening about the pockets of deprivation, racism, and separation from civil society that apply as much to youg mothers as to tireslashing boys on acid."-Melissa Benn, New Statesman \& Society $\$ 17.00$

\section{The Management of Conflict}

Interpretations and Interests in Comparative Perspective

\section{Marc Howard Ross}

"This is the best book I know of on conflict management for today's political scene. In contrast to its rivals, Ross's theory of conflict resolution is deeply integrated with our best theories on ethnocentrism and other sources of intergroup conflict."-Donald T. Campbell $\$ 14.00$

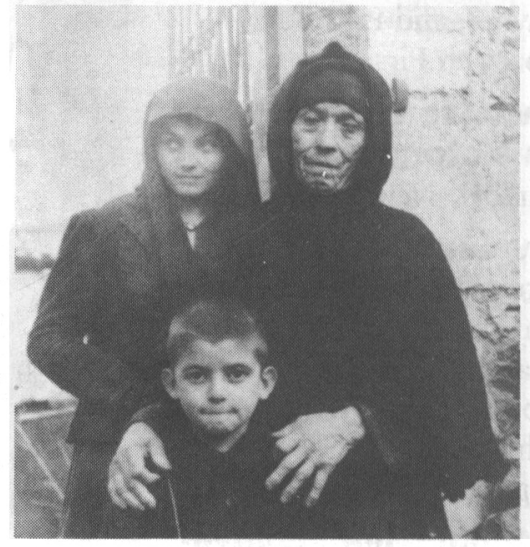

\section{Inside Hitler's Greece}

The Experience of Occupation, 1941-1944

\section{Mark Mazower}

"A superb book on the horrors afflicting wartime Greece. ...[Mazower] has done vast archival research and emerged with a gripping, readable and human account, setting every moment of a tragic period in appropriate context."-Fritz Stern, Foreign Affairs 70 illus. $\$ 18.00$

Joint winner of the 1993 Fraenkel Prize in Contemporary History

Winner of the 1994 Longman/History Today Prize

\section{Law's Promise, Law's Expression}

Visions of Power in the Politics of Race, Gender, and Religion

\section{Kenneth L. Karst}

"A reasoned and cogent response to those who complain about the judicialization of politics. Karst demonstrates that the social issues agenda is inextricably bound up in law. This book is required reading for all those interested in the cultural revolution of the 1960s and 1970s and the counter revolution that informs so much of our national politics today."-Thomas Edsall $\$ 16.00$ 
Inaugural volumes in the Annals of Communism series

The Secret World of American Communism

Harvey Klehr, John Earl Haynes, and Fridrikh Igorevich Firsov

"A wonderfully rich and revelatory book."-David Garrow, New York Newsday

"A valuable book....It proves beyond any question that the [CPUSA functioned as an instrument of Soviet espionage."-Arthur Schlesinger, Jr., The New Republic

\section{"A formidable achieve-}

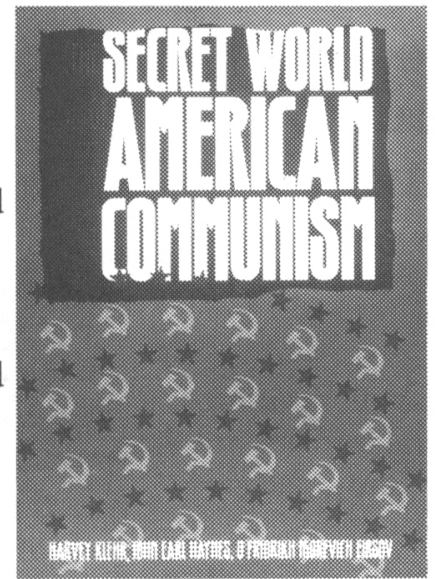

ment. ...No one will be able to write about the CPUSA in the future without reference to this volume."Maurice Isserman, The Nation

"This book contains the first new revelation about American communism in a generation. It is superbly edited and admirably presented. No one interested in the history of American communism can afford to miss it."-Theodore Draper $\$ 25.00$

\section{Stalin's Letters to Molotov, 1925-1936}

Edited by Lars T. Lih, Oleg V. Naumov, and Oleg V. Khlevniuk

\section{"A tantalizing glimpse} of the despot."-Serge Schmemann, The New York Times

"Fascinating....Provide [s] the best insight yet into the workings of Stalin's political mind."-Steven Merritt Miner, New York Times Book Review

"Chilling reading.....A wealth of insights into the early years of Stalin's rule." -Mark Kramer, Chicago Tribune

"The exchanges printed here give us Bolshevik thought in the raw, in all its crudity and coarseness."-Robert Conquest $\$ 25.00$

To order call 1-800-YUP-READ

\section{Yale University Press}

P.O. Box 209040, New Haven, CT 06520
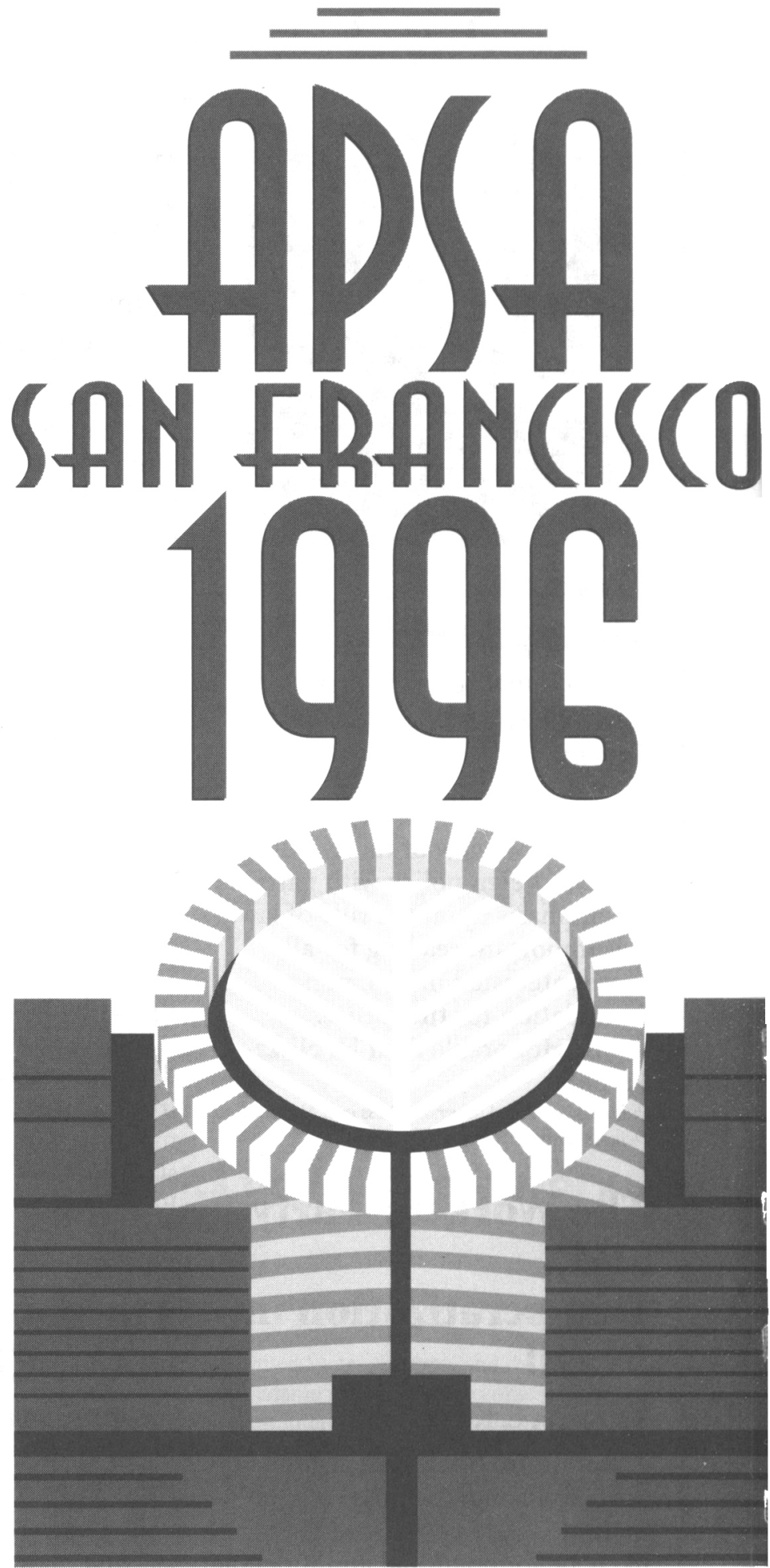

ANNOUNCING

92ND ANWUAL MECTING AND EXHIBTTION

AUGUST 29 - SEPTEMBER 1 SAM FRAMYISCO HILTON AND TOWERS 
Texts and Canons: The Status of the "Great Books" in Political Science Arlene W. Saxonhouse, University of Michigan

Political Theory in the 1980s: Perplexity Amidst Diversity William Galston, University of Maryland

Feminist Challenges to Political Science Susan J. Carroll and Linda M. G. Zerilli, Rutgers University

Formal Rational Choice Theory: A Cumulative Science of Politics David Lalman, Joe Oppenheimer, and Piotr Swistak University of Maryland

The Comparative Method David Collier, University of California-Berkeley

The State of Quantitative Political Methodology Larry M. Bartels, Princeton University and Henry E. Brady, University of CaliforniaBerkeley

Comparative Political Parties: Research and Theory Kenneth Janda, Northwestern University

The Not So Simple Act of Voting Russell J. Dalton and Martin P. Wattenberg, University of California-Irvine

The New Look in Public Opinion Research Paul M. Sniderman, Stanford University

New Edition... New Contributors...

\section{Political Science:}

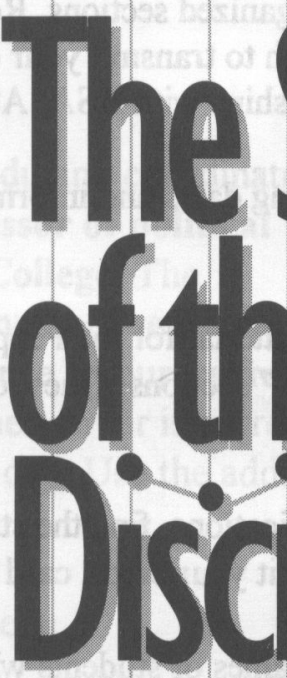

Edited by

\section{AdaW.Finifter}

American Political Science Association

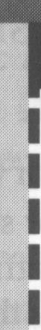

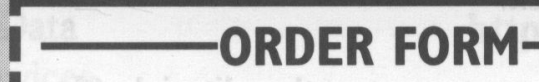

a Please send me copies of Political Science: The State of the Discipline II.

My check is enclosed for $\$$

口 Charge my: $\square$ MasterCard a VISA Exp. date:

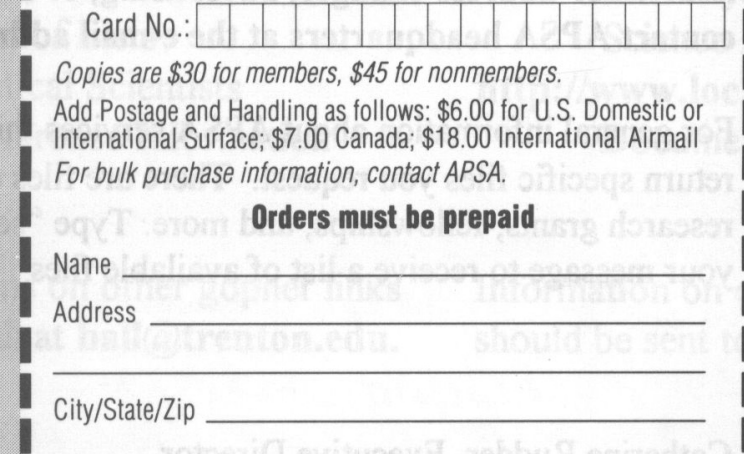

1

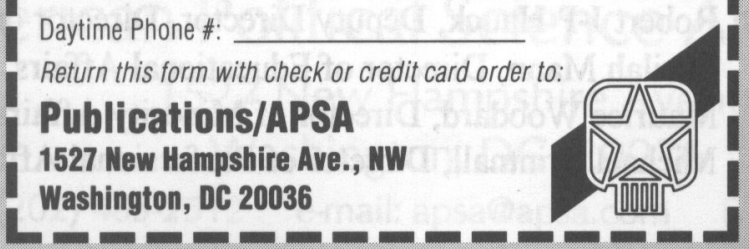

Expanding Disciplinary

Boundaries: Black, Latino, and

Racial Minority Group Politics in

Political Science

Paula D. McClain, University of Virginia and John A. Garcia, University of Arizona

Citizens, Contexts, and Politics

Robert Huckfeldt, Indiana

University and John Sprague,

Washington University

Political Communication:

Scope, Progress, Promise

Doris Graber, University of

Illinois at Chicago

Legislatures: Individual

Purpose and Institutional

Performance

Michael L. Mezey,

DePaul University

Public Law and Judicial Politics

Martin Shapiro, University of

California-Berkeley

Political Executives and Their

Officials

Colin Campbell, S.J.,

Georgetown University

Public Administration: The State of the Field

Donald F. Kettl, University of

Wisconsin

Comparative Politics

Ronald Rogowski, University of

California-Los Angeles

Global Political Economy

James A. Caporaso, University of Washington

Political Conflict, War, and

Peace

Jacek Kugler, The Claremont Graduate School 


\section{CONTACTING APSA BY E-MAIL}

apsa@apsa.com

membership@apsa.com

meeting@apsa.com

PS@apsa.com

publications@apsa.com

minority_id@apsa.com

PSN@apsa.com

advertising@apsa.com

apsr@ssc.msu.edu

information@apsa.com

The APSA Political

Scientists on E-mail:

rudder@apsa.com

rhauck@apsa.com

smann@apsa.com

woodard@apsa.com

brintnall@apsa.com
Use this address for general inquries about APSA services not mentioned below.

send mail to this address to receive information about membership rates and services to APSA and it's organized sections. Request an address change or renew your membership (if you wish to transmit your credit card number by e-mail). Find out about joint memberships with ASA, ASIL, and AHA.

Find out future annual meeting dates and information, including the 1996 Call for Papers.

Use this address to submit material for the People in Political Science Section and for the "News and Notes" sections; Questions about deadlines and manuscript submissions.

Receive a list of APSA publications, find the status of an order, and place orders (if you wish to transmit your credit card number by e-mail).

Use this address to submit names of students who are candidates for the minority identification project and to request additional information about the program

Send employment listings to the Personnel Service Newsletter, a monthly publication listing employment opportunities for political scientists.

Obtain insertion rates for advertising in PS, APSR, and the Annual Meeting Final Program.

Use this address to contact the editorial office of the American Political Science Review. Please note that instruction for submission of articles to the review are printed in each issue. The editorial office does not handle business issues. For address changes, advertising, or other non-editorial issues, please contact APSA headquarters at the e-mail addresses listed above.

For general information about APSA services this automated server will return specific files you request. There are files on membership, publications, research grants, fellowships, and more. Type "send list" in the subject field of your message to receive a list of available files

\section{Catherine Rudder, Executive Director}

Robert J-P Hauck, Deputy Director, Director of International Programs

Sheilah Mann, Director of Educational Affairs

Maurice Woodard, Director of Minority Affairs

Michael Brintnall, Director of Professional Affairs 


\title{
APSA ON THE INTERNET
}

The American Political Science Association (APSA) e-mail addresses and gopher server allow political scientists faster, more efficient ways to access information and services.

\section{APSA GOPHER}

Located at apsa.trenton.edu and coordinated by

Bill Ball, assistant professor of political science, Trenton State College. The APSA gopher provides an effective means of retrieving political science resources from the Internet. The APSA gopher server is currently averaging 180 accesses a day. Use the address below:

\section{apsa.trenton.edu root menu}

About the APSA Gopher

American Government Gopher at

Northwestern University

Comparative Politics

International Relations

Political Theory

Public Policy and Public Administration

Computers, Software \& Data

APSA Information \& Services

Conference Information

Journal Information

Scholarships, Fellowships, \& Grants

The Political Science List of Lists

E-Mail Directory of Political Scientists

Related Gophers and Reference Information

Questions and suggestions on other gopher links should be sent to Bill Ball at ball@trenton.edu.

\section{PSRTL, THE POLITICAL SCIENCE} RESEARCH AND TEACHING LIST

The APSA gopher server is designed to work in conjunction with the Political Science Research and Teaching List (psrt-1) which itself has 1,420 subscribers in 44 countries. PSRT-L is a Listserv discussion group (send the command "subscribe psrt-l your name" to listserv@mizzou1.missouri.edu). To send messages to current subscribers of the list, send mail to psrt-1@mizzou1.missouri.edu.

\section{WORLD WIDE WEB SITES FOR POLITICAL SCIENTISTS}

The World Wide Web (WWW) allows users to view text as well as graphics, video, and sound. Like the gopher, special software is needed to access web pages. The following sites contain information relevant to political science:

http://www.un.org

United Nations news and documents

http://osiris.colorado.edu/ prq/prq.html Political Research Quarterly, the official journal of the Western Political Science Association

http://www.loc.gov

Documents from the Library of Congress

Information on other political science web sites should be sent to psrt-1@mizzou1.missouri.edu

\section{American Political Science Association}

\author{
1527 New Hampshire Avenue, NW \\ Washington, DC 20036
}

Phone: (202) 483-2512 e-mail: apsa@apsa.com Fax: (202) 483-2657 


\section{Why Should I Join The American Political Science Addociation?}

\section{To participate in the advancement of the discipline and the profession.}

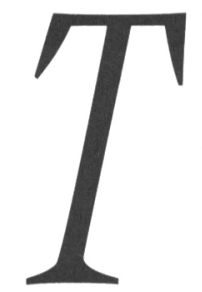

he American Political

Science Association is the major professional society for those engaged in the study of politics.

Our mission is to reach out to scholars, teachers, students and others throughout the world to facilitate learning, teaching, and research in the field of political science.

To do so, we foster support for political science research and teaching, facilitate employment, promote equity and diversity in the profession, further professional ethics, sponsor awards for scholarly excellence, and develop teaching materials. We provide opportunities for communicating in and across fields, presenting research, publishing articles, and participating in a variety of special programs.

\section{To invest in the professional development of your own career.}

Members of the American Political Science Association receive a wide range of benefits, including:

Subscriptiond to the American Political Science Review, the leading journal of political science research, and $P S$, the only quarterly professional news journal in the political science field.

Eligibility for special member programs such as:

- Membership on association committees and governing bodies with a direct impact on the profession.

- Membership in Organized Sections.

- Employment services such as Personnel Service Newsletter.

- APSA research grants.

- APSA fellowships.

Discounts and special reduced rates for members only on:

- APSA's annual meeting, attended by thousands of political scientists from around the world. Our members get discounts on registration, airfare, and hotel rates.

- APSA's publications, including directories, research and professional guides, instructional resources, software, and more.

- Subscriptions to over 100 periodicals from other organizations.

- Memberships in the American Historical Association, the American Sociological Association, and the American Society of International Law.

- Hertz car rentals.

- Membership in Quest (a travel company that provides attractive, reduced-rate hotel rooms for professional travel in the U.S. and abroad).

Lidting in the APSA Membership Directory, widely used in the U.S. and abroad to provide information about individual political scientists and their interests, and consequently as a source of professional opportunities.
Photocopy the Membership Application on the opposite page and mail or fax to:
AMERICAN POLITICAL SCIENCE ASSOCIATION

1527 New Hampshire Avenue, N.W., Washington, DC 20036

FAX: (202) 483-2512 • PHONE (202) 483-2657

e-mail: membership@apsa.dgsys.com 


\section{APSA \\ Membership Application Form}

$\square$ WORK

Phone

Name

Address

City

State

Zip

APSA will mail to your home unless you specify otherwise:

Address to use for Renewals: $\square$ Home $\square$ Work

Address to use for Journals: $\square$ Home a Work

\section{- HOME}

Phone Fax

Name

Address

City State Zip

\section{MEMBERSHIP DUES (CHECK ONE)}

\section{APSA Members}

with gross calendar income:

over $\$ 60,000$

$\$ 50,000$ - $\$ 59,999$

$\$ 40,000-\$ 49,999$

$\$ 30,000-\$ 39,999$

under $\$ 30,000$

Student Members (limit 5 years)
$\$ 95.00$ 口

$\$ 90.00$ 口

$\$ 85.00$ 口

$\$ 75.00$ 口

$\$ 55.00$ 口

$\$ 25.00$ 口
Retired Members (who have been members 25 years) with gross calendar income:
under $\$ 25,000$
$\$ 20.00$
$\$ 25,000$ and over
$\$ 40.00$
Life Members
$\$ 2,000$
Associate Members* (for non-political scientists) \$25.00 a
Family Members*
$\$ 10.00 \square$
* Does not include subscriptions to APSR or PS.

\section{SECTION DUES (CHECK ANY YOU WISH TO JOIN)}

1. Federalism and Intergovernmental Relations

2. Law and Courts

3. Legislative Studies

4. Public Policy

5. Political Organizations and Parties

6. Public Administration

7. Conflict Processes

8. Representation and Electoral Systems

9. Presidency Research

10. Political Methodology

11. Religion and Politics

12. Politics and Life Sciences

13. Urban Politics

14. Applied Political Science

15. Science, Technology, and Environmental Politics

16. Women and Politics

17. Foundations of Political Theory
18. Computers and Multimedia

$\$ 5.00$

$\$ 8.00 \square$

$\$ 10.00$

$\$ 8.00$

$\$ 5.00$ 口

$\$ 5.00$

$\$ 5.00$

$\$ 5.00$

$\$ 7.00$

$\$ 8.00$

$\$ 6.00$

$\$ 5.00$

$\$ 10.000$

$\$ 5.00$

$\$ 8.00$

$\$ 8.00$

$\$ 8.00$

19. International Security and Arms Control

20. Comparative Politics

32. Elections, Public Opinion \&

Voting Behavior

33. Race, Ethnicity and Politics
22. State Politics \& Policy $\$ 7.00$

23. Political Communication $\$ 8.00$

24. Politics and History \$8.00

25. Political Economy $\$ 7.00$

26. Transformational Politics $\$ 5.00$

27. New Political Science $\$ 5.00$

28. Political Psychology $\$ 8.00$

29. Experiential Education $\$ 5.00$ 口

30. Politics and Literature $\$ 5.00$ 口

31. Domestic Sources of Foreign Policy $\$ 5.00$ 口

(call)

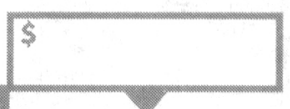

\section{PERSONNEL SERVICE}

a Personnel Service Newsletter

a Credential Referral Service

$\square$ Address to use for newsletter

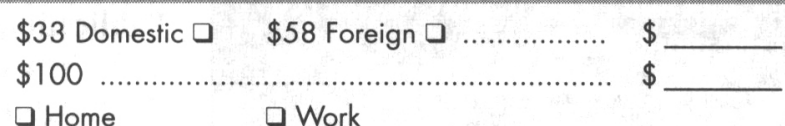

a Home a Work

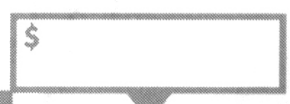

\section{METHOD OF PAYMENT (CHECK ONE)}

$\square$ Check (payable to APSA) a Visa

a Foreign check processing $-\$ 15$

Card \#

Signature

\section{- MasterCard \\ - Money Order \\ a Mail to addresses outside the US} Exp. Date

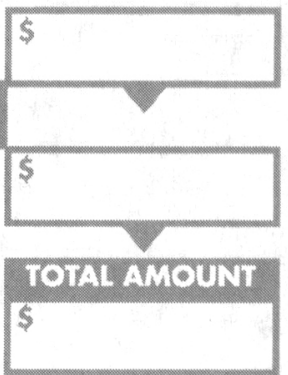




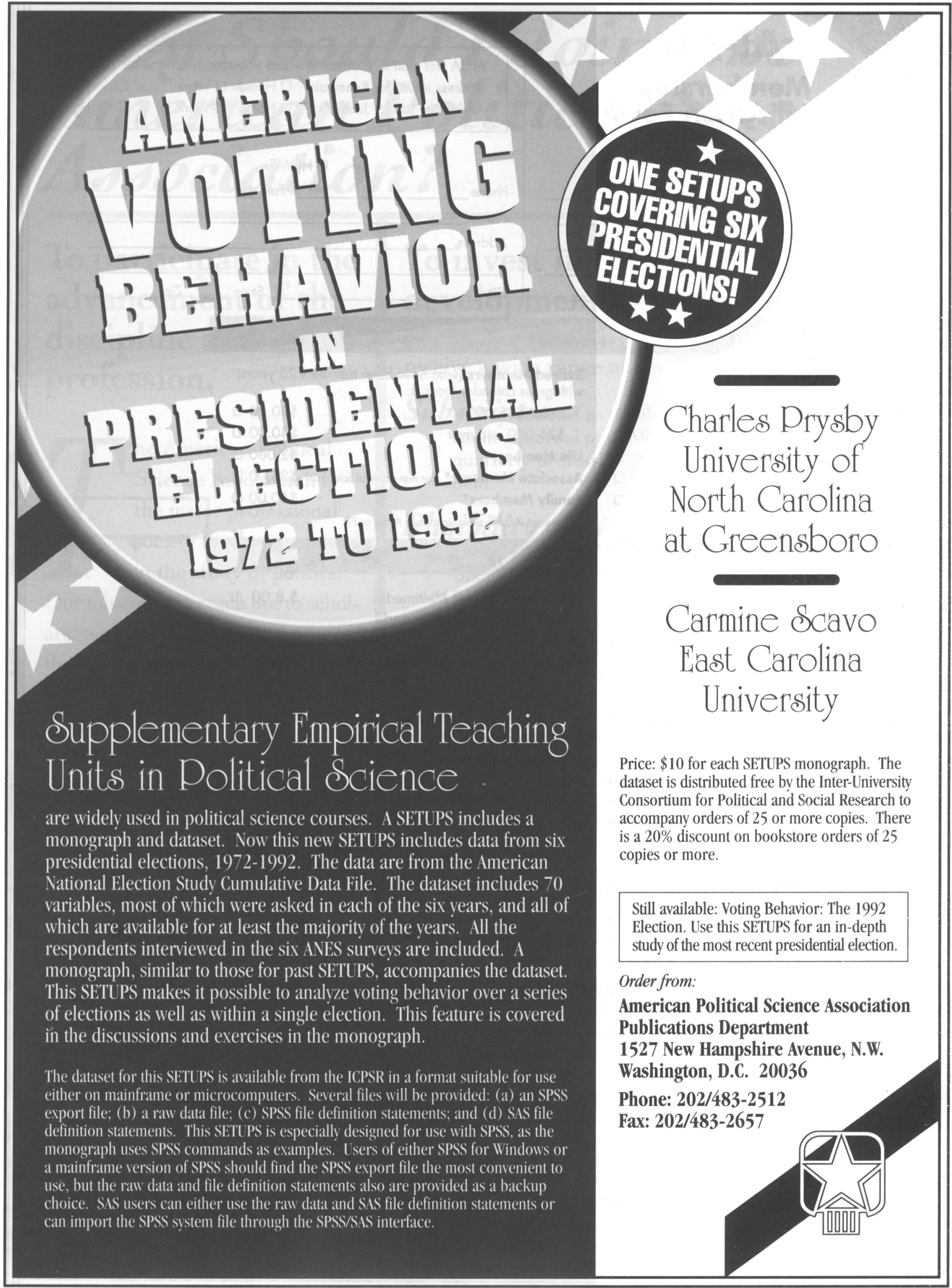




\section{American Democracy in Peril}

Seven Challenges to America's Future. Revised edition.

William E. Hudson, Providence College

"This text provides a provocative challenge to complacency about the state of American politics. Written with clarity and verve, it will compel students to contest familiar assumptions and to think hard about our institutions, social structure, and values. American Democracy in Peril is the kind of book that can make teaching come alive."

1-56643-030-5 paper

Ira Katznelson, Columbia University Instructor's Manual Available

\section{American Public Policy: Promise and Performance. Fourth edition.} B. Guy Peters, University of Pittsburgh

One of the best-selling texts in public policy has been thoroughly revised and updated. Peters clearly explicates the policy-making process and has added a section on crime and law enforcement.

1-56643-024-0 paper

Instructor's Manual Available

\section{The Clinton Presidency: First Appraisals}

Edited by Colin Campbell, Georgetown University, and Bert A. Rockman, University of Pittsburgh

In the tradition of The Reagan Legacy and The Bush Presidency, twelve original essays by some of our foremost political scientists critically examine the performance of the Clinton administration. Highly appropriate for courses in American politics as well as the presidency.

1-56643-014-3 paper

1-56643-013-5 cloth

\section{Democracy's Feast: Elections in America}

\section{Edited by Herbert $\mathbf{F}$. Weisberg, Ohio State University}

"This book fills the enormous void between casual punditry and incomprehensible analysis. The authors treat the data with respect, but their main interest is politics, thank God, not data."

1-56643-011-9 paper

William Schneider, $\mathrm{CNN}$

\section{In Pursuit of the White House}

\section{How We Choose Our Presidential Nominees}

\section{Edited by William G. Mayer, Northeastern University}

"A superb collection of original research on the presidential nominating process, In Pursuit of the White House should be required reading for reporters covering the 1996 campaign and for all students of American electoral politics."

1-56643-027-5 paper

Thomas E. Mann, The Brookings Institution

\section{The Politics of Disappointment: American Elections, 1976-94 Wilson Carey McWilliams, Rutgers University}

"This brilliant book proves once again that he is one of the country's most gifted and perceptive students of our great democratic experiment."

E.J. Dionne, Jr., author of Why Americans Hate Politics 1-56643-028-3 paper

\section{The Politics of Gun Control}

\section{Robert J. Spitzer, SUYY, College at Cortland}

"This is a book that has been begging to be written. A terrific book - thorough, informative, and balanced. Looking at gun control through the broader framework of social regulatory policy, the author cuts through the cant surrounding this hot issue and offers all of us new perspectives on a contemporary policy quandary."

\section{Presidential Elections}

\section{Strategies and Structures of American Politics. Ninth edition}

Nelson W. Polsby and Aaron Wildavsky, University of California, Berkeley

Polsby has completely revised and updated this classic study of politicians' strategic choices and voter behavior in presidential elections. The book comprehensively covers parties, primaries, national conventions, campaigns and their organizations, and mass voting behavior. The new edition takes account of trends reflected in the elections of 1994 and relates them to the presidential contests of the preceding three decades, setting the stage for the 1996 election. 


\section{Table of Contents}

\section{ARTICLES}

Dynamic Representation

James A. Stimson, Michael B. MacKuen, and Robert S. Erikson....... 543

Campaign Contributions and Access

David Austen-Smith ...

A Grammar of Institutions

Sue E. S. Crawford and Elinor Ostrom

The Advantage of Being Moderately Cooperative

Tomonori Morikawa, John M. Orbell, and Audun S. Runde

Thick-Skinned Liberalism: Redefining Civility

Richard C. Sinopoli.

Mary Astell (1666-1731), Critic of Locke

Patricia Springborg

What To Do (and Not to Do) with Time-Series-Cross-Section

Data in Comparative Politics

Nathaniel Beck and Jonathan N. Katz

Coalition Termination and the Strategic Timing of

Parliamentary Elections

Arthur Lupia and Kaare Strøm.

\section{RESEARCH NOTES}

Waltz, Durkheim, and International Relations:

The International System as an Abnormal Form

John Barkdull . . . . . . . . . . . . . . . . . . . . . . . . . 669

The Consequences of Negotiated Settlements in Civil Wars, 1945-1993

Roy Licklider................................. 681

Issue Fluidity on the U.S. Supreme Court

Kevin T. McGuire and Barbara Palmer ..................... 691

\section{CONTROVERSIES}

The Empirical Evidence for Citizen Information and a Local Market

for Public Goods

David Lowery, W. E. Lyons, and Ruth Hoogland DeHoog;

Paul Teske, Mark Schneider, Michael Mintrom, and Samuel Best .... 705

The Enactment of Mothers' Pensions: Civic Mobilization and Agenda Setting or Benefits of the Ballot?

Cheryl Logan Sparks and Peter R. Walniuk; Theda Skocpol......... 710

NOTES FROM THE MANAGING EDITOR .................. 731

\section{BOOK REVIEWS}

Political Theory ..................................... 738

American Politics ........................................... 756

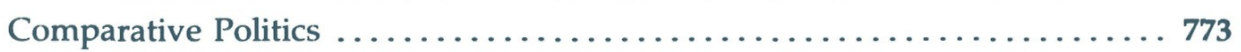

International Relations........................... 794 